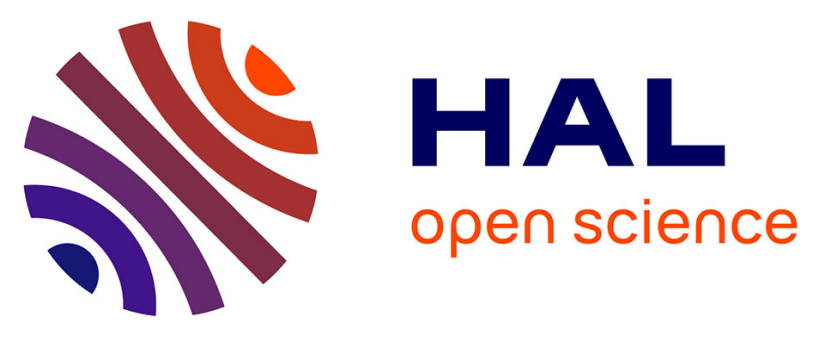

\title{
Unusual LREE-rich, peraluminous, monazite- or allanite-bearing pegmatitic granite in the central Grenville Province, Québec
}

François Turlin, Anne-Sylvie André-Mayer, Abdelali Moukhsil, Olivier Vanderhaeghe, Félix Gervais, Fabien Solgadi, Pierre-Arthur Groulier, Marc Poujol

\section{To cite this version:}

François Turlin, Anne-Sylvie André-Mayer, Abdelali Moukhsil, Olivier Vanderhaeghe, Félix Gervais, et al.. Unusual LREE-rich, peraluminous, monazite- or allanite-bearing pegmatitic granite in the central Grenville Province, Québec. Ore Geology Reviews, 2017, 89, pp.627-667. 10.1016/j.oregeorev.2017.04.019 . insu-01524603

\section{HAL Id: insu-01524603 https://hal-insu.archives-ouvertes.fr/insu-01524603}

Submitted on 18 May 2017

HAL is a multi-disciplinary open access archive for the deposit and dissemination of scientific research documents, whether they are published or not. The documents may come from teaching and research institutions in France or abroad, or from public or private research centers.
L'archive ouverte pluridisciplinaire HAL, est destinée au dépôt et à la diffusion de documents scientifiques de niveau recherche, publiés ou non, émanant des établissements d'enseignement et de recherche français ou étrangers, des laboratoires publics ou privés. 


\section{Accepted Manuscript}

Unusual LREE-rich, peraluminous, monazite- or allanite-bearing pegmatitic granite in the central Grenville Province, Québec

François Turlin, Anne-Sylvie André-Mayer, Abdelali Moukhsil, Olivier Vanderhaeghe, Félix Gervais, Fabien Solgadi, Pierre-Arthur Groulier, Marc Poujol

PII: S0169-1368(17)30057-4

DOI: http://dx.doi.org/10.1016/j.oregeorev.2017.04.019

Reference: OREGEO 2186

To appear in:

$$
\text { Ore Geology Reviews }
$$

Received Date: $\quad 23$ January 2017

Revised Date: $\quad 19$ April 2017

Accepted Date: $\quad 24$ April 2017

Please cite this article as: F. Turlin, A-S. André-Mayer, A. Moukhsil, O. Vanderhaeghe, F. Gervais, F. Solgadi, PA. Groulier, M. Poujol, Unusual LREE-rich, peraluminous, monazite- or allanite-bearing pegmatitic granite in the central Grenville Province, Québec, Ore Geology Reviews (2017), doi: http://dx.doi.org/10.1016/j.oregeorev. 2017.04.019

This is a PDF file of an unedited manuscript that has been accepted for publication. As a service to our customers we are providing this early version of the manuscript. The manuscript will undergo copyediting, typesetting, and review of the resulting proof before it is published in its final form. Please note that during the production process errors may be discovered which could affect the content, and all legal disclaimers that apply to the journal pertain. 
1 Unusual LREE-rich, peraluminous, monazite- or allanite-bearing 2 pegmatitic granite in the central Grenville Province, Québec

3 François Turlin ${ }^{\mathrm{a}, *}$, Anne-Sylvie André-Mayer ${ }^{\mathrm{a}}$, Abdelali Moukhsil ${ }^{\mathrm{b}}$, Olivier 4 Vanderhaeghe $^{\text {c }}$, Félix Gervais ${ }^{\mathrm{d}}$, Fabien Solgadi ${ }^{\mathrm{e}}$, Pierre-Arthur Groulier ${ }^{\mathrm{f}}$, Marc Poujol ${ }^{\mathrm{g}}$

5 a GeoRessources lab., UMR 7359, Université de Lorraine, CNRS, CREGU, Faculté des

6 Sciences et Technologies, Vandouvre-lès-Nancy, F-54506, France

7 b Ministère de l'Énergie et des Ressources naturelles, Direction du Bureau de la 8 connaissance géoscientifique du Québec, 5700, 4 Avenue Ouest, Québec (Québec), G1H 6R1

$9{ }^{\mathrm{c}}$ Géosciences Environnement Toulouse, GET, Université de Toulouse, CNRS, IRD, UPS, CNES (Toulouse), France

11 d Département des génies civil, géologiques et des mines, Ecole Polytechnique de Montréal, 12 Canada

13 ' Ministère de l'Énergie et des Ressources naturelles, Direction du Bureau de la connaissance 14 géoscientifique du Québec, 400, boulevard Lamaque, Val-d'Or (Québec), J9P 3L4

$15{ }^{\mathrm{f}}$ Earth Sciences Department, Memorial University, St. John's, NL A1B 3X5, Canada

16 Géosciences Rennes, UMR 6118, OSUR, Université de Rennes 1, 35042 Rennes Cedex, 17 France

18 * Corresponding author: François Turlin

Université de Lorraine, CNRS, CREGU, GeoRessources lab. Campus Aiguillettes, Faculté des Sciences et Technologies rue Jacques Callot Vandœuvre-lès-Nancy, F-54506, France.

Mail: francois.turlin@univ-lorraine.fr

Phone: +33 383684767 


\section{Abstract}

This contribution presents an original study combining detailed mapping, petrography, whole-rock geochemistry and geochronological constraints on the recently identified LREE (Light Rare Earth Elements) occurrences associated with pegmatitic granite dykes (PGD) from the central Grenville (Lac Okaopéo region). These PGD intrude paragneisses or metaigneous complexes with a REE mineralization hosted either in monazite-(Ce) or in allanite(Ce) respectively. The investigated samples display peraluminous signatures and are dominated by a quartz+K-feldspar+plagioclase+biotite+monazite/allanite assemblage. Field relationships and the magmatic textures of the dykes combined with $\mathrm{U}-\mathrm{Pb}$ dating of magmatic monazite grains at $1005.4 \pm 4.4 \mathrm{Ma}$ and $996.7 \pm 5.3 \mathrm{Ma}$ (concordant igneous ages) imply that the LREE-rich PGD were emplaced in a post-tectonic setting. Allanite-(Ce) and monazite(Ce)-bearing PGD have RREE contents up to $9242 \mathrm{ppm}$ and $7048 \mathrm{ppm}$, respectively. The allanite-rich assemblage is consistent with the petrographic assemblage of LREE-enriched PGD identified in the southwestern Grenville Province and elsewhere in the world, but this study constitutes the first evidence for a sole presence of monazite as LREE-bearing phase in strongly peraluminous PGD from the Grenville Province.

Keywords: Grenville Province; Peraluminous; Pegmatitic Granite; LREE; Whole-rock geochemistry; Allanite/Monazite 


\section{Introduction}

Granitic pegmatites host numerous metallic occurrences, mostly rare-metals such as U-Th, Nb-Ta, Y, Rare Earth Elements (REE), Ti, Zr, Be, Li, Cs, Mo, Rb, B, P, Pb, F. Due to their small sizes, REE-rich granitic pegmatites are generally not considered as good economic target when compared to their plutonic counterparts, and have thus not received the same attention (e.g. Ercit, 2005; Goodenough et al., 2016; London, 2016). However, the worldwide overwhelming occurrences of REE-bearing granitic pegmatites may potentially represent important sources of REE and are to be included in the further global investigations of the REE metallogenic system. The lack of detailed field descriptions, whole-rock and mineralogical compositions, as well as structural data for the pegmatitic bodies and their host and country rocks prevent a good understanding of the source, the formation and the concentration of REE-bearing pegmatites (Dill, 2015; Ercit, 2005). Classification schemes, such as the NYF (Nb-Y-F) classes of Černý et al. (2012) or the "chessboard" scheme of Dill (2010), generally depict REE-rich granitic pegmatites as being derived from an alkaline melt fractionation (Dill, 2010, 2015). However, in some cases (e.g. in the Grenville Province) where the lack of coeval granitic pluton is not necessarily due to a lack of outcrops, a derivation of REE-rich granitic pegmatites from partial melting of a crustal/sub-crustal component is generally inferred, but not clearly demonstrated (Ercit, 2005 and references therein).

With this in mind, the Proterozoic Grenville Province, mainly exposed in Quebec and Ontario (Canada, Fig. 1), offers the possibility to study numerous magmatic REE occurrences, mainly late- to post-Grenvillian in age, and associated with a large spectrum of magmatic environments including nepheline-syenite (e.g. Saint-Honoré, Crevier, Bergeron, 1980; Gauthier and Chartrand, 2005; Groulier, 2013; Sangster et al., 1992), carbonatite (e.g. Niobec, Crevier, Bergeron, 1980; Groulier, 2013), as well as numerous granitic pegmatites (e.g. Ayres 
and Černý, 1982; Černý, 1990; Ercit, 2005; Ford, 1982; Lentz, 1996; Masson and Gordon, 1981; Moukhsil et al., 2014). Other "non-magmatic" REE occurrences are described in this province such as the metasomatic mineralization of Kipawa or the Kwyjibo IOCG-type deposit, with a REE mineralization dated at ca. 1030 Ma (Saucier et al., 2013; van Breemen and Currie, 2004) and ca. 985-970 Ma (Gauthier et al., 2004; Perreault and Lafrance, 2015 and references therein), respectively.

During the past few decades, several studies investigated the distribution, mineralogy and petrogenesis of granitic pegmatites from the Grenville Province (Ayres and Černý, 1982; Černý, 1990; Fowler and Doig, 1983; Lentz, 1996, 1991; Masson and Gordon, 1981). They typically comprise with U-Th, Nb-Ta, Y, Ti, Zr, REE, Be, Mo, P, Pb, F (Ayres and Černý, 1982; Černý, 1990; Fowler and Doig, 1983; Gauthier and Chartrand, 2005; Lentz, 1996; Masson and Gordon, 1981). They are generally interpreted as representing a silicate melt extracted from partially molten rocks between ca. 1.1 to $0.9 \mathrm{Ga}$ during the late stages of major intrusive events coeval with the end of Grenvillian high-grade metamorphism based on (i) the lack of coeval granitic pluton, (ii) their magmatic and undeformed texture, and (iii) their discordant and intrusive nature in brittle zones within competent units (Ayres and Černý, 1982; Ercit, 2005; Lentz, 1991; Lumbers, 1964; Masson and Gordon, 1981). Accordingly, the presence of REE-enriched pegmatitic granite dykes (further designated as 'PGD') in the Grenville Province raises the question of (i) the source of these magmas and (ii) the geodynamic context that prevailed during their emplacement. Were these granitic magmas produced by partial melting of the thermally relaxed orogenic root composed of reworked Archean and/or Proterozoic pre-existing continental crust, or do they correspond to extremely differentiated mantle melts produced by decompression owing to post-orogenic extension?

The previous studies mentioned above have been mainly focused on the western parts of the Grenville Province and, to our knowledge, no REE-rich PGD have been described in 
the central part of the Grenville Province (Fig. 1). A recent campaign of cartography in the Lac Okaopéo region conducted by Moukhsil et al. (2014) (Figs. 2-3) has led to the identification of seven REE magmatic occurrences associated with discordant PGD intrusive either in migmatitic paragneisses or in metaplutonic complexes (Fig. 3, Table 1, Moukhsil et al., 2014). These PGD have $\Sigma$ REE contents ranging from 1418 to 9242 ppm (this study, Table 2) and represent new REE occurrences in the Grenville Province. The present paper is dedicated (i) to describe the field relationships between the various PGD and their host rocks to constrain their structural framework; (ii) to characterize their petrography and whole-rock geochemistry, allowing to discuss potential sources and processes responsible for their emplacement and concentration; and (iii) to constrain the timing of REE mineralization by LA-ICP-MS U-Pb dating on monazite in order to replace these PGD in the tectonicmetamorphic framework of the Grenvillian Orogeny. Finally, these results will be compared to other LREE-enriched granitic pegmatites reported elsewhere.

\section{Geological framework}

\subsection{The Grenville Orogenic Belt}

The study area is located in the central Grenville Province (Fig. 1b), which mainly crops out along the southeastern Canadian Shield (Fig. 1a). It results from a long history of tectonic-magmatic accretion through the Mesoproterozoic and subsequent continent-continent collision designated as the Grenvillian Orogeny sensu stricto (e.g. Carr et al., 2000; Dunning and Indares, 2010; Gower and Krogh, 2002; Rivers et al., 2012; Tucker and Gower, 1994).

\section{FIGURE 1}

The two main tectonometamorphic domains of the Grenville Province, namely the Allochthonous and the Parautochthonous belts recorded the Grenvillian Orogeny as two distinct phases. The Allochthonous Belt (Fig. 1b) is made of terranes that originated outboard 
of, and were accreted to Laurentia during the Mesoproterozoic (Rivers et al., 2012). The

118 underlying Parautochthonous Belt (Fig. 1b) corresponds to rocks of the Superior Province and

119 its cover sequence or to previously accreted arc that were reworked during the Grenvillian

120 Orogeny (Rivers et al., 1989, 2012). The Allochthonous and the Parautochthonous belts are

121 separated by the southeast-dipping and orogen-scale high-grade shear zone designated as the

122 Allochthon Boundary Thrust (ABT, Figs. 1b, 2). The "Ottawan" crustal thickening phase is

123 first of the Grenvillian Orogeny, and was characterized by the development of a hot ductile crust underneath an orogenic plateau ("Orogenic Lid", Fig. 1b) with a lower limit inferred to be the ABT, between ca. 1090 and 1020 Ma in the Allochthonous Belt (e.g. Carr et al., 2000; Dunning and Indares, 2010; Indares et al., 2000; Rivers, 2008, 1997; Rivers et al., 2012). This plateau is inferred to have collapsed on itself after the Ottawan phase resulting in the formation of several normal-sense shear zones commonly associated with the emplacement of PGD, and assisted by the intrusion of AMCG suites that resulted in weakening and lubricating of the shear zones (Ketchum et al., 1998; Rivers, 2012; Rivers and Schwerdtner, 2015; Soucy

131 La Roche et al., 2015). Renewed convergence during the relatively short-lived Rigolet phase

132 (1005-960 Ma, Rivers, 2009) resulted in foreland-ward propagation of Grenvillian thrusting 133 and high-grade metamorphism, the northwest limit of which is the Grenville Front (Fig. 1), an orogen-scale, southeast-dipping shear zone that was active during the Rigolet orogenic phase

135 (Krogh, 1994; Rivers et al., 1989; Rivers, 2008, 2009). Synkinematic PGD and sills were intruded at upper and lower structural levels of the Parautochthonous and Allochthonous belts, respectively, between 993 and 961 Ma during this later phase on the south shore of the

138 Manicouagan Reservoir (Fig. 2, Jannin et al., In press). peak at ca. $1450 \mathrm{MPa}$ and $860-900^{\circ} \mathrm{C}$ between ca. 1080-1040 Ma (Indares et al., 1998; Indares

141 and Dunning, 2001; Lasalle et al., 2013; Lasalle and Indares, 2014; Rivers et al., 2002) in 
142 kyanite-bearing rocks from the Manicouagan Imbricate Zone (MIZ, central Grenville, Fig. 2),

143 a high-grade nappe of Paleoproterozoic and Mesoproterozoic rocks of the Allochthonous HP

144 Belt (aHP, Fig. 1b). It was followed by the exhumation of the MIZ over a crustal-scale ramp 145 structurally above the Parautochthonous Belt at ca. $1100 \mathrm{MPa}$ and $870^{\circ} \mathrm{C}$ between ca. $1040-$ 1461030 Ma (Indares et al., 1998; Indares and Dunning, 2001; Lasalle et al., 2013; Lasalle and 147 Indares, 2014; Rivers et al., 2002), and by the subsequent pervasive intrusion of mantle148 derived magmas in the thickened orogenic crust (e.g. Dunning and Indares, 2010; Hynes et 149 al., 2000; Indares et al., 2000; Indares and Dunning, 2004). South of the Manicouagan 150 reservoir (just north of our study area; Fig. 2), however, peak metamorphic conditions at 151 sillimanite-grade conditions reached ca. $950 \mathrm{MPa}$ and $850^{\circ} \mathrm{C}$ between ca. 1080 and $1040 \mathrm{Ma}$ 152 (Dunning and Indares, 2010; Lasalle et al., 2014; Lasalle and Indares, 2014). In the

153 Parautochthonous Belt south of the reservoir, granulite-facies peak metamorphic conditions of ca. $1500 \mathrm{MPa}$ and $850^{\circ} \mathrm{C}$ were reached between ca. 1005-980 Ma (Hynes et al., 2000; Jordan et al., 2006; Rivers, 2009; Rivers et al., 2012; van Gool et al., 2008) in metapelites from the

156 Knob Lake Group Paleoproterozoic sequence of the Gagnon Terrane that unconformably

157 overlie the Laurentian Archean basement (Parautochthonous Belt, Fig. 2, Dunning and 158 Indares, 2010; Hynes et al., 2000; Rivers, 1980; Rivers et al., 1989). A recent study indicated 159 that high-grade deformation continued until at least ca. $986 \mathrm{Ma}$ (but could be as young ca. 961

$160 \mathrm{Ma}$ ) as rocks of the upper and lower parts of the Parautochthonous and the Allochthonous 161 belts, respectively, were likely flowing as an orogenic channel (Jannin et al., In press).

\section{FIGURE 2}

\subsection{The Lac Okaopéo lithotectonic units and structures}

The Lac Okaopéo region is located south of the MIZ and of the Daniel-Johnson dam

165 (Manic-5, Fig. 2). The various lithotectonic units identified in this region (Gobeil et al., 2002; 
Moukhsil et al., 2014, 2013a, 2013b, 2012, 2009, 2007) belong to the Allochthonous MP Belt

167 of the Grenville Province, structurally above the Allochthon Boundary Thrust (ABT, Fig. 2).

\section{FIGURE 3}

\subsubsection{PGD host rocks}

The PGD investigated in this study are hosted either in paragneisses or in two distinct metaplutonic suites, designated as the Bardoux and the Castoréum. The paragneisses from the Plus-Value Complex mainly crop out in the northwestern part of the region (Fig. 3) and are the oldest protolith in the region with a deposition age between 1765 to $1497 \mathrm{Ma}$ (Augland et al., 2015; Lasalle et al., 2013; Moukhsil et al., 2014, 2013b).

The Bardoux plutonic suite (Fig. 3) is a greyish metagranite dominated by a metaluminous I-type to minor peraluminous S-type signature with millimetric garnet and biotite completed with phenocrysts (up to $5 \mathrm{~cm}$ ) of K-feldspar (microcline) showing locally rapakivi texture, and containing some enclaves of diorite, monzonite and monzodiorite, that represent continental-arc granitoids emplaced into the Laurentian margin (Augland et al., 2015; Moukhsil et al., 2014, 2012). It has been dated at 1487.6 $\pm 6.8 \mathrm{Ma}$ in the Lac du Milieu

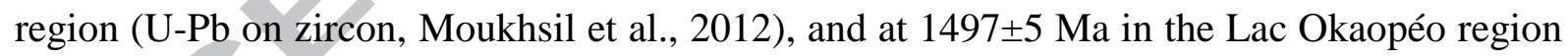
(U-Pb on zircon, Augland et al., 2015). The Castoréum Plutonic Suite, which is intrusive in the Plus-Value Complex and in the Bardoux Plutonic Suite (Fig. 3), is dominated by a facies of homogeneous porphyric to porphyroclastic metagranite with a metamorphic fabric delineated by the preferred orientation of biotite, hornblende and recrystallized or fractured feldspar phenocrysts (Moukhsil et al., 2014, 2013b). It is associated with minor charnockite, mangerite, granitic gneisses, and metatonalite (Moukhsil et al., 2014, 2013b). It has been dated at $1393 \pm 8 \mathrm{Ma}(\mathrm{U}-\mathrm{Pb}$ on zircon) and emplaced in an arc-setting (Augland et al., 2015).

\subsubsection{Other lithotectonic units exposed in the Lac Okaopéo region}


191 the PGD (Fig. 3). All are younger than the Plus-Value Complex paragneisses and the Bardoux

192 Plutonic Suite but their emplacement ages spread over the pre-Grenvillian and Grenvillian 193 history. Pre-Grenvillian units include granitic to dioritic orthogneisses, metamangerite and

194 metagranite. As they were emplaced between $1450 \mathrm{Ma}$ and $1100 \mathrm{Ma}$ (Augland et al., 2015;

195 David et al., 2009; Gobeil et al., 2002; Moukhsil et al., 2007, 2012, 2013a, 2013b, 2014), their

196 emplacement, encompasses most of the Mesoproterozoic evolution of the Province from the 197 late-Pinwarian (ca. 1470-1450 Ma, Ketchum et al., 1994; Tucker and Gower, 1994) to the 198 post-Elzevirian (ca. 1245-1225 Ma, Rivers et al., 2012). Several Grenvillian units are coeval 199 with the Ottawan peak of high-grade metamorphism and include granitic to quartz 200 monzodioritic orthogneisses, monzonitic to granitic slightly deformed plutons, and 201 undeformed mafic rocks (David, 2006; Dunning and Indares, 2010; Moukhsil et al., 2007, 202 2009, 2013b, 2014). Late-Ottawan units include the Berté anorthosite intrusive in the Renwick Mangerite; the weakly deformed metaluminous mangerite and charnockite \pm leuconorite \pm granite from the Céline Plutonic Suite (undated), ascribed to the volcanic arc granite domain; the Sabot Mangerite (ca. 1016-1017 Ma); and the high-alkalic

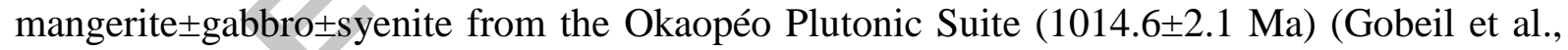

207 2002; Moukhsil et al., 2007, 2009, 2013a, 2013b, 2014).

\section{Sampling and analytical methods}

\subsection{Sampling}

The seven PGD sampled for this study are accessible by gravel roads branching from 211 the 389 highway, from Baie-Comeau to the Daniel Johnson dam (Manic-5, Figs. 2-3). They 212 are located in the northwestern part of the studied region (NTS sheets 22K/07 and 22K/10, 213 Figs. 2-3, Table 1), and are aligned along a north to south trend (Fig. 3, Moukhsil et al., 
215 feldspar+plagioclase+biotite \pm monazite/allanite (Figs. 4, 6-7, Appendices A-B). Their color 216 and mineralogy are correlated to the nature of the intruded lithologies. Dykes hosted in 217 paragneisses of the Plus-Value Complex are whitish and contain monazite $218\left[(\mathrm{Ce}, \mathrm{La}, \mathrm{Nd}, \mathrm{Th}) \mathrm{PO}_{4}\right]$ as the LREE-bearing phase (outcrops 13-AM-07, -10, -13 and 13-TC219 5008, Figs. 6, 8-10), while those hosted in metaplutonic complexes of the Bardoux and 220 Castoréum Plutonic Suites are pinkish (fresh color) and contain allanite $221\left[(\mathrm{Ce}, \mathrm{Ca})_{2}\left(\mathrm{Al}, \mathrm{Fe}^{3+}\right)_{3}\left(\mathrm{SiO}_{4}\right)_{3}(\mathrm{OH})\right]$ (outcrops 13-TC-5072, 13-FS-1202 and 13-AE-2149, Figs. $2227,11-12)$.

\subsection{Whole rock geochemistry}

Whole-rock geochemistry of the most REE enriched facies of the PGD identified on

each outcrop was performed by Actlabs (Ancaster, Ontario). Samples were chosen according to the abundance of REE phases, i.e. monazite and allanite, and using a RS125 scintillometer allowing for the identification of LREE-rich and LREE-poor facies as they are hosted in UTh-bearing phases. Powdered samples were prepared by Li-metaborate or -tetraborate. Major elements were analysed by inductively coupled plasma - atomic emission spectroscopy (ICP-

230 AES), and trace elements by inductively coupled plasma - mass spectrometry (ICP-MS).

231 Results are reported in Table 2. In the present contribution, we report original geochemical 232 data and we include an analysis from Moukhsil et al. (2014) for sample 13-AE-2149 (Tables $1-2)$.

\subsection{Electron microprobe (EMP)}

Element composition and chemical maps were obtained by the Electron Microprobe 236 (EMP) method using a Cameca computer-controlled SX-100 (GeoRessources, Nancy) equipped with a wavelength dispersive spectrometer (WDS). 
For quantitative analyses and chemical mapping of monazite from the 13-AM-13 and the 13-TC-5008 PGD, major and trace elements (Si, P, Ca, Y, La, Ce, Pr, Nd, Sm, Gd, Pb, Th, $\mathrm{U})$ were measured using an accelerating voltage of $20 \mathrm{kV}$ and a beam current of $100 \mathrm{nA}$. Peak counting time was set to $120 \mathrm{~s}$ for $\mathrm{Pb}, 100 \mathrm{~s}$ for $\mathrm{U}$ and $20 \mathrm{~s}$ for the others elements. Results are reported in Table 3. Chemical mapping were realized at $15 \mathrm{kV}$ and $100 \mathrm{nA}$, using a stage scanning mode. Dwell time per pixel was adjusted to $30 \mathrm{~ms}$ and pixel step range from 0.3 to $0.9 \mu \mathrm{m}$. The chosen X-ray lines were: $\mathrm{Ca} K \alpha, \mathrm{Th} M \alpha, \mathrm{U} M \beta, \mathrm{Y} L \alpha$ and $\mathrm{Ce} L \alpha$. Maps are reported in Fig. 9.

For quantitative analyses of allanite from the 13-TC-5072 and the 13-FS-1202 PGD, major and trace elements (F, Mg, Al, Si, P, K, Ca, Ti, Mn, Fe, Sr, Y, La, Ce, Pr, Nd, Sm, Gd, $\mathrm{Pb}, \mathrm{Th}, \mathrm{U})$ were measured using an accelerating voltage of $20 \mathrm{kV}$ and a beam current of 100 nA. Peak counting time was set to $120 \mathrm{~s}$ for $\mathrm{Pb}, 100 \mathrm{~s}$ for $\mathrm{U}$ and $20 \mathrm{~s}$ for the others elements. Results are reported in Table 4.

\subsection{U-Pb dating on monazite using Laser Ablation-Inductively Coupled Plasma-Mass}

\section{Spectrometry (LA-ICP-MS)} was conducted directly on thin sections at Géosciences Rennes (France) by in-situ laser ablation inductively coupled plasma mass spectrometry (LA-ICP-MS) using a ESI NWR193UC Excimer laser coupled to a quadripole Agilent 7700x ICP-MS.

The signals of ${ }^{204}(\mathrm{~Pb}+\mathrm{Hg}),{ }^{206} \mathrm{~Pb},{ }^{207} \mathrm{~Pb},{ }^{208} \mathrm{~Pb}$ and ${ }^{238} \mathrm{U}$ masses have been acquired 258 during the course of the analyses. The ${ }^{235} \mathrm{U}$ signal is calculated from ${ }^{238} \mathrm{U}$ on the basis of the 259 ratio ${ }^{238} \mathrm{U} /{ }^{235} \mathrm{U}=137.88$. Single analyses consisted of $20 \mathrm{~s}$ of background integration followed 260 by $60 \mathrm{~s}$ integration with the laser firing followed by a $10 \mathrm{~s}$ delay to wash out the previous sample. Spot diameters of $10 \mu \mathrm{m}$ associated with repetition rates of $2 \mathrm{~Hz}$ and a laser fluency 
262 of $6.5 \mathrm{~J} . \mathrm{cm}^{-2}$ were used during the present study. For more information on the settings of the

263 instrument, see Ballouard et al. (2015) and the Appendix D for details and operating 264 conditions of the LA-ICP-MS measurements. Data reduction was carried out with the 265 GLITTER $®$ software package developed by the Macquarie Research Ltd (Van Achterbergh et 266 al., 2001). Raw data were corrected for $\mathrm{Pb} / \mathrm{U}$ laser-induced elemental fractionation and for 267 instrumental mass discrimination by standard bracketing with repeated measurements of the 268 Moacir monazite standard (Gasquet et al., 2010). To control the reproducibility and accuracy 269 of the corrections, repeated analyses of the Manangoutry monazite standard (554.8 $\pm 4.2 \mathrm{Ma}$; $270 \mathrm{MSWD}=0.94, \mathrm{n}=8$ for the 13-AM-13 sample; 554.4 $\pm 3.4 \mathrm{Ma}$; MSWD $=0.94, \mathrm{n}=8$ for the

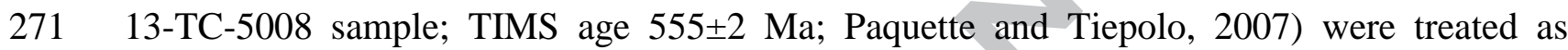
272 unknown. No common $\mathrm{Pb}$ correction was applied. Concordia diagrams were generated using 273 Isoplot/Ex (Ludwig, 2001). All errors given in Table 5 are listed at 1 sigma.

\section{Outcrop description and detailed mapping}

\subsection{Monazite-bearing PGD (paragneisses-hosted)}

Four of the REE occurrences associated with PGD identified by Moukhsil et al. (2014)

277 intrude migmatitic paragneisses of the Plus-Value Complex (Fig. 3). An example of detailed 278 mapping of a monazite-bearing PGD (13-AM-13 outcrop) is provided in Fig. 4, and detailed 279 description and mapping for each of the monazite-bearing outcrops are provided in Appendix 280 A. Structural measurements of the dykes' walls and of the foliation of the host rocks are 281 indicated for each outcrop in Appendix C.

\section{FIGURE 4}

To the north of the studied area, PGD are exposed within small (a few square meters 284 in surface) and flat lying outcrops (Fig. 6a) or steep-dipping outcrop along a gravel road. They 285 are made of decimeter- to decameter-sized single dyke bodies with steeply dipping to 
subvertical walls trending N/S to locally NW/SE or NE/SW that dominantly plunge towards

287 south, and are strongly (Fig. 6b) to slightly (Fig. 6c) discordant to the foliation of their host 288 (Fig. 5a). Stockscheider-like textures delineate the contact between the 13-AM-07 PGD and 289 the intruded paragneisses (Fig. 6b). All contacts are slightly (over a few millimeters, Fig. 6b) 290 to locally diffuse (outcrop 13-TC-5008, Fig. 6c) and do not correspond to fractures 291 crosscutting the host-rock minerals (Fig. 6c). These PGD display various facies that are (i) 292 fine grained ( $1 \mathrm{~mm}$ to over $1 \mathrm{~cm}$, Fig. $6 \mathrm{~b}$ and d) with garnet and sub-euhedral monazite (Figs. 293 6e, f), (ii) intermediate, (iii) coarse-grained (sometimes over $3 \mathrm{~cm}$, Fig. 6d) dominated by quartz and feldspar with minor biotite, and (iv) pegmatitic dominated by quartz+feldspar \pm biotite (Fig. 6g) with very few accessory phases, no garnet and few monazite crystals. The transition between the fine- and coarse-grained facies is diffuse but is locally underlined by biotite aggregates (Fig. 6d). Locally, skeletal biotite (up to $15 \mathrm{~cm}$ crystals) are arranged as an arborescent texture (Fig. 6h). Up to ca. $20 \mathrm{~cm}$ centimeters wide quartz aggregates are expressed with no identifiable link with any of the previous facies (Fig. 4).

\section{FIGURE 5}

\section{FIGURE 6}

These PGD with monazite as the REE-hosting mineral, will further be referred as 'monazite-bearing' (or 'Mnz-bearing') PGD.

\subsection{Allanite-bearing PGD (metaplutonic complexes-hosted)}

Three of the REE occurrences associated with PGD identified by Moukhsil et al. (2014) intrude the metaplutonic complexes of the Bardoux or the Castoréum Plutonic Suite

307 (Fig. 3). Detailed mapping and description for each of the allanite-bearing outcrops are provided in Appendix B and structural measurements of the dykes' walls and of the foliation of the host rocks are indicated for each outcrop in Appendix C. 
311 flat lying or large steep-dipping (Fig. 7e). Two of these outcrops (13-TC-5072 and 13-FS-

312 1202) are made of decimeter- to meter-sized dyke swarms with steeply dipping to subvertical

313 walls trending NW/SE to locally N/S or NE/SW that plunge variably towards north and south,

314 and are slightly to strongly discordant to the foliation of their host metamonzogranite and

315 quartz metamonzodiorite (Fig. 5b), respectively. The contacts of these two dykes with their

316 host is slightly diffuse (over a few millimeters, Fig. 7c). One outcrop (13-AE-2149), is made

317 of a main shallow dipping dyke oriented NE/SW that plunges towards the north, in textural

318 continuity to granitic veins concordant/discordant to the foliation of the host metamangerite

319 (Figs. 5b, 7e-f). This dyke is slightly discordant to locally sub-concordant to the foliation of

320 its host rock (Fig. 5b) and locally show a very diffuse contact with its host rock at its lower

321 contact (Fig. 7g). None of the contacts of the allanite-bearing PGD correspond to fractures crosscutting the host-rock minerals (Figs. 7c and g).

The metamonzogranite-hosted PGD (13-TC-5072) typically display a fine-grained quartz+feldspar \pm biotite facies at the contact, with northern boundaries usually marked by Kfeldspar phenocrysts (Fig. 7c), and an increasing grain size towards the allanite-rich pegmatitic core that are delineated by biotite aggregates (southern boundary for the dyke represented in Fig. 7c). Allanite from this outcrop may reach several centimeters (Figs. 7c-d). When zoned, the quartz metamonzodiorite-hosted PGD (13-FS-1202) display an internal layering marked by coarse (over $3 \mathrm{~cm}$ ) allanite-rich and barren facies alternating with fine330 grained $(0.1-3 \mathrm{~cm})$ allanite-rich facies (Fig. 7b). The metamangerite-hosted PGD (13-AE2149) is a ca. $1 \mathrm{~m}$ wide dyke (Fig. 7e), which displays diffuse contacts with its host rock, the

332 lower being more diffuse than the upper (Fig. $7 \mathrm{~g}$ ). Upper and lower contacts are marked by 333 ca. $20 \mathrm{~cm}$ and ca. $45 \mathrm{~cm}$ wide pegmatitic facies (some grains being over $10 \mathrm{~cm}$ in size) 334 respectively, composed of quartz+feldspar \pm disseminated allanite phenocrysts. The latter are 
oriented with their long axis perpendicular to the contact (Fig. $7 \mathrm{~g}$ ). The core of the dyke is a

336 layered fine-grained facies with ca. $30 \mathrm{~cm}$ long quartz+K-feldspar-rich lenses that alternate 337 with quartz-plagioclase-rich lenses (Fig. 7g).

\section{FIGURE 7}

These PGD with allanite as the REE-hosting mineral, will further be referred as

'allanite-bearing' (or 'Aln-bearing') PGD.

\section{Detailed petrography of the monazite- and allanite-bearing PGD}

\subsection{Petrography of the monazite-bearing PGD (paragneisses-hosted)}

All monazite-bearing PGD are dominated by a quartz+K-feldspar+plagioclase \pm biotite assemblage (Fig. 8a), with a grain size spreading from millimeter to several centimeters (up to $5 \mathrm{~cm}$ in some facies). It is completed with minor garnet, zircon and monazite that are more abundant in the finest grained facies, and accessory rare pyrite and Ti-oxides. All facies show a magmatic texture and lack evidence for solid-state deformation (Fig. 8a).

\section{FIGURE 8}

The monazite crystals from paragneisses-hosted PGD have been investigated in two PGD (the 13-AM-13 and the 13-TC-5008, Figs. 8a-c, 9). In both cases, monazite is expressed as pristine sub-millimetric to several millimeters wide crystals that do not show any signs of corrosion/dissolution. A main difference between monazite crystals from these two samples

353 lies in their inner textures and composition (Figs. 9-10, Table 3).

\section{FIGURE 9}

Monazite grains from the 13-AM-13 PGD show oscillatory zoning with a $L R E E(\mathrm{Ce})$ -

356 rich core surrounded by several overgrowths with a composition grading toward a Th-Si-rich 357 pole (Figs. 9a-c). These zones display monazite-(Ce) compositions that shift towards 
monazite-(La) compositions with increasing proportion of Th and Si (Fig. 10a) that is consistent with the concurrent increase in huttonite end-member (from $3.78 \%$ to $12.27 \%$, Fig. 10b, Table 3), where Th or $U+\mathrm{Si}=\mathrm{REE}+\mathrm{P}$ (Spear and Pyle, 2002). The proportion of brabantite (from $8.66 \%$ to $9.62 \%$ ) remains quite stable (Fig. 10b, Table 3).

Monazite grains from the 13-TC-5008 PGD are rather homogeneous or weakly zoned as expressed in SEM and X-ray maps. Chemical zoning consists of three zones that grade from a $\operatorname{LREE}(\mathrm{Ce})$-rich to a Th-Si-rich composition toward the grain boundaries as identified in X-ray maps (Figs. 9d-f, Table 3). The compositions of all the grains are clustered into the monazite-(Ce) field (Fig. 10c) as marked by the quite stable $\mathrm{P}_{2} \mathrm{O}_{5}$, and REE oxides contents (Table 3) from $L R E E(C e)$-rich zones to Th-Si-rich overgrowths. A slight increase in $\mathrm{SiO}_{2}$ and $\mathrm{ThO}_{2}$ is consistent with the increase in huttonite end-member (from $4.02 \%$ to $5.39 \%$, Fig. 10d). The proportion of brabantite (from $2.77 \%$ to $3.37 \%$ ) remains quite stable (Fig. 10d, Table 3). Plotted in a $\mathrm{Th}+\mathrm{U}+\mathrm{Si}$ vs $\mathrm{REE}+\mathrm{Y}+\mathrm{P}$ diagram, the three investigated zones cluster and spread along a narrow range of the huttonite substitution curve (Fig. 10d).

\section{FIGURE 10}

Monazite-bearing PGD also comprise sub-euhedral zircon grains (up to 1-1.5 mm, Fig. $8 b)$ that may represent up to ca. $1 \%$ of the whole assemblage, mainly in fine grained to intermediate facies. Late-magmatic Th-U( \pm REE) silicates (Fig. $8 \mathrm{c})$ are present as interstitial few micrometers wide bands in the vicinity of or as filling fractures of monazite crystals. Finally, sericite is expressed as an alteration product of feldspar (K-feldspar and plagioclase, Fig. 8d).

\subsection{Petrography of the allanite-bearing PGD (metaplutonic complexes-hosted)}

All allanite-bearing PGD are dominated by a quartz+K-feldspar+plagioclase \pm biotite (Figs. 11a-c) assemblage with a grain size ranging from millimeter to several centimeters 
382 (over $10 \mathrm{~cm}$ in some pegmatitic facies, outcrop 13-AE-2149). This assemblage is completed

383 with zircon and allanite, and rare apatite (some grains are present in the pegmatitic facies of 384 the 13-AE-2149 outcrop). The abundance of accessory minerals is not correlated with the 385 grain size. All facies display a magmatic texture and lack evidence for solid-state deformation 386 (Figs. 11a-c).

\section{FIGURE 11}

The textural characteristics of allanite from metaplutonic complexes-hosted PGD depend on the host granite. Allanite crystals were investigated in the 13-TC-5072 and the 13FS-1202 samples and in both cases are sub-euhedral and sub-millimetric to several 391 millimeters wide (Figs. 6b-d, g, 11b-c).

Allanite grains from the 13-TC-5072 PGD show an oscillatory zoned core, further designated as 'Aln 1 ', corroded and crosscut by an overgrowth of a second generation of intermediate composition allanite, further designated as 'Aln ' (Fig. 11b), that forms the subeuhedral shape of allanite phenocrysts. It is surrounded by an alteration rim (Fig. 11b). These three zones cluster as typical allanite compositions plotted in the REE vs Al diagram (Fig. 12a) of Petrík et al. (1995) and display quite similar compositions, except for the decrease in $\mathrm{FeO}$ (from 11.11 to $9.76 \mathrm{wt}$ \%) content from the $\mathrm{Aln}_{1}$ cores to the alteration rims (Table 4).

Allanite grains from the 13-FS-1202 PGD display internal patchy zoning between 'LREE(Ce)-rich' and 'Fe-Ca-LREE(Ce)-rich' zones (Fig. 11d). They are surrounded by an in the REE vs Al diagram (Fig. 12b) of Petrík et al. (1995). The Fe-Ca-LREE(Ce)-rich zone

403 displays the most allanite-like composition, whereas the alteration rim is marked by a shift 404 towards the epidote composition (Fig. 12b) associated with an increase in $\mathrm{SiO}_{2}$ and a decrease in LREE (Table 4). 
Allanite-bearing PGD also contain sub-euhedral zircon grains (up to 1-1.5 mm, Figs.

408

409

410

411

412

\section{Whole-rock geochemistry of the monazite- and allanite-bearing PGD}

\subsection{Geochemistry of the monazite-bearing PGD (paragneisses-hosted)}

Three of the four monazite-bearing PGD (samples 13-AM-07, 13-AM-10 and 13-TC5008) display typical granitic composition with a $\mathrm{SiO}_{2}$ content of 71.03 wt.\%, 70.80 wt.\% and 70.79 wt.\% respectively (Table 2), and a strong peraluminous character (Fig. 13a) as marked by their (i) ASI (Aluminum Saturation Index, ASI $=\mathrm{Al} /(\mathrm{Ca}-1.67 \mathrm{x} \mathrm{P}+\mathrm{Na}+\mathrm{K})$ Frost et al., 2001; Shand, 1943), (ii) A/CNK (A/CNK = Al/(Na + K + Ca/2), Shand, 1943), and (iii) A/NK $(\mathrm{A} / \mathrm{NK}=\mathrm{Al} /(\mathrm{Na}+\mathrm{K})$, Shand, 1943) above $1.19,1.27$ and 1.55 respectively (Table 2$)$. In contrast, one monazite-bearing PGD (13-AM-13) does not display a typical granitic composition as its $\mathrm{SiO}_{2}$ content is down to $60.24 \mathrm{wt} \%$ (Table 2). This low content is associated with the highest $\mathrm{Al}_{2} \mathrm{O}_{3}, \mathrm{CaO}$ and $\mathrm{Na}_{2} \mathrm{O}$ contents of 18.58 wt.\%, 3.10 wt.\% and 4.02 wt.\% respectively, and a low $\mathrm{K}_{2} \mathrm{O}$ content of $4.36 \mathrm{wt} . \%$ leading to the highest ASI ratio of the monazite-bearing serie at 1.36 (Table 2) that corresponds to a strongly peraluminous signature (Fig. 13a).

All the monazite-bearing samples display high LREE content ranging from 1418 to 7048 ppm (Table 2). Their REE patterns are strongly fractionated in LREE over HREE (Fig. 13b), as evidenced by the $\mathrm{La}_{\mathrm{N}} / \mathrm{Yb}_{\mathrm{N}}$ ratios ranging from 784 to 938 (Table 2), and more or less 
430

431

432

433

434

435

436

437

438

439

440

441

443

444

445

446

developed Eu negative anomaly (Fig. 13b), which intensity increases with the $\Sigma$ REE content, as marked by decreasing $\mathrm{Eu} / \mathrm{Eu}^{*}$ from 0.72 down to 0.14 (Table 2). The $\Sigma$ REE content is also associated with (i) increasing $\mathrm{U}$ and Th contents (up to 19.10 and $1300 \mathrm{ppm}$ respectively, Fig. 13c, Table 2) and $\mathrm{Nb} / \mathrm{Ta}$ ratio (up to 56 with $\mathrm{Nb}$ ranging from 5.60 to $21 \mathrm{ppm}$ and Ta ranging from 0.10 to 0.40 ppm, Fig. 13e, Table 2), (ii) increasing $\mathrm{Na}_{2} \mathrm{O}, \mathrm{CaO}$ and $\mathrm{P}_{2} \mathrm{O}_{5}$ contents (up to 4.02, 3.10, 0.40 wt.\% respectively, Figs. $13 \mathrm{~d}$ and f, Table 2), and (iii) decreasing $\mathrm{K}_{2} \mathrm{O}$ content (down to 4.36 wt.\%, Fig. 13d, Table 2). The $\Sigma$ REE content of monazite-bearing PGD is not linked to the $\mathrm{Fe}_{2} \mathrm{O}_{3}$ (total) nor $\mathrm{MgO}$ contents (Fig. 13g, Table 2). The $\mathrm{Zr} / \mathrm{Hf}$ ratios are quite stable (ranging from 36 to 44, Fig. 13e, Table 2) with $\mathrm{Zr}$ ranging from 195 to $1480 \mathrm{ppm}$ and Hf ranging from 4.40 to 41.50 ppm (Fig. 13e, Table 2).

\section{FIGURE 13}

\subsection{Geochemistry of the allanite-bearing PGD (metaplutonic complexes-hosted)}

Two of the three allanite-bearing PGD (samples 13-TC-5072 and 13-FS-1202) have typical granitic composition with a $\mathrm{SiO}_{2}$ content of 70.27 wt.\% and 70.85 wt.\% respectively (Table 2), and a strong peraluminous character (Fig. 13a) as marked by their ASI, A/CNK, and A/NK over 1.18, 1.24 and 1.64 respectively (Table 2). In contrast, one of the PGD (sample 13-AE-2149) does not display a typical granitic composition as $\mathrm{its} \mathrm{SiO}_{2}$ content is down to 55.84 wt.\% (Table 2). This low content is associated with the highest $\mathrm{Al}_{2} \mathrm{O}_{3}, \mathrm{CaO}$, $\mathrm{Na}_{2} \mathrm{O}$ contents of 15.05 wt.\%, 5.54 wt.\%, 4.28 wt.\% respectively, and a low $\mathrm{K}_{2} \mathrm{O}$ content of 1.93 wt. $\%$, leading to the lowest ASI and A/CNK ratio of the allanite-bearing serie at 1.08 and 0.87 (Table 2) that corresponds to a weakly peraluminous signature (Fig. 13a).

All the allanite-bearing samples display high $\Sigma$ REE content ranging from 2393 to 9242 ppm (Table 2). The REE patterns of the 13-TC-5072 and 13-FS-1202 samples are strongly fractionated in LREE over HREE (Fig. 13b), as evidenced by the $\mathrm{La}_{\mathrm{N}} / \mathrm{Yb}_{\mathrm{N}}$ ratios 
454

455

456

457

458

459

460

461

462

463

464

465

466

467

468

469

470

471

472

473

474

475

476

ranging from 261 to 619 (Table 2). The REE pattern of the low-SiO 2 PGD (13-AE-2149 sample) is more enriched in HREE and displays a less fractionated pattern, as marked by its lower $\mathrm{La}_{\mathrm{N}} / \mathrm{Yb}_{\mathrm{N}}$ ratio of 28 (Table 2). The intensity of the negative Eu anomaly increases with the $\Sigma$ REE content as shown by decreasing Eu/Eu* from 0.36 down to 0.12 (Table 2). The $\Sigma$ REE content is also associated with (i) increasing $\mathrm{U}$ and Th contents (up to 30.30 and 766 ppm respectively, Fig. 13c, Table 2), (ii) increasing $\mathrm{Na}_{2} \mathrm{O}, \mathrm{CaO}, \mathrm{Fe}_{2} \mathrm{O}_{3}$ (total) and $\mathrm{MgO}$ contents (up to $4.28,5.54,12.42$ and 0.85 wt.\% respectively, Figs. $13 \mathrm{~d}$ and g, Table 2), and (iii) decreasing $\mathrm{K}_{2} \mathrm{O}$ content (down to 1.33 wt.\%, Fig. 13d, Table 2) and $\mathrm{Nb} / \mathrm{Ta}$ ratio (down to 41 with $\mathrm{Nb}$ ranging from 7.50 to $132 \mathrm{ppm}$ and Ta ranging 0.11 to $3.20 \mathrm{ppm}$, Fig. 13e, Table 2).

The $\Sigma$ REE content of allanite-bearing granite dykes is not linked to the $\mathrm{P}_{2} \mathrm{O}_{5}$ content (Fig. 13f, Table 2), nor to the $\mathrm{Zr} / \mathrm{Hf}$ ratios that remain quite stable (ranging from 35 to 39, Fig. 13e, Table 2) with $\mathrm{Zr}$ ranging from 290 to $6340 \mathrm{ppm}$ and $\mathrm{Hf}$ ranging from 7.40 to $171 \mathrm{ppm}$ (Fig. 13e, Table 2).

\section{U-Pb dating of magmatic monazite}

Monazite grains from the paragneiss-hosted 13-AM-13 PGD have been investigated through 25 analyses performed directly on thin sections on 7 different grains. Plotted on a concordia diagram, data define a discordia yielding an upper intercept of $1003.9 \pm 4.7 \mathrm{Ma}$ $(\mathrm{MSWD}=0.43)$ if the lower intercept is anchored to $0 \pm 0 \mathrm{Ma}$ (Fig. 14a, Table 5). Eleven of these 25 analyses are concordant and define a concordia age (as of Ludwig, 1998) of 996.7 $\pm 5.3 \mathrm{Ma}(\mathrm{MSWD}=0.98$, Fig. 14b). Even though the monazite grains from this sample are zoned (Figs. 9a-c, 10a-b), these data do not show any signs of inherited cores with distinctly older ages nor isotopic heterogeneity within a grain as all the data spread on the same discordia and point to a single upper intercept date (Fig. 14a). 
The monazite grains from the paragneisses-hosted 13-TC-5008 PGD have been

478 investigated through 22 analyses performed on 9 different grains. Plotted on a concordia

479 diagram, data plot on the concordia curve, and yield a concordia age of $1005.4 \pm 4.4 \mathrm{Ma}$ $480($ MSWD = 1.01; Fig. 14c, Table 5). As for the 13-AM-13 PGD, these data do not point to the 481 presence of inherited cores with an older age nor heterogeneity within a grain as all the data 482 plot on the concordia curve (Fig. 14c). This is consistent with the lack of chemical zoning on 483 the studied monazite grains (Figs. 9d-f, 10c-d).

FIGURE 14

\section{Discussion}

\subsection{LREE-rich PGD from the Lac Okapéo region in the frame of the Grenvillian}

\section{Orogeny}

The Grenville Province hosts numerous granitic pegmatites (e.g. Ayres and Černý, 1982; Černý, 1990; Ercit, 2005; Ford, 1982; Fowler and Doig, 1983; Lentz, 1996, 1991; Lumbers, 1979; Masson and Gordon, 1981), mainly in the Central Gneiss Belt, in the Central

Metasedimentary Belt, in the Central Granulite Terrain and in the Eastern Grenville (Fig. 1b).

They are discordant and intrusive in brittle zones within competent units, show magmatic and undeformed texture, and geochronological constraints evidence for their late-Grenvillian

494 Orogeny timing of emplacement (Ford, 1982; Fowler and Doig, 1983; Lentz, 1996, 1991, Lumbers, 1979, 1964). These granitic pegmatites are assumed to be either derived (i) from partial melting of paragneiss and/or orthogneiss, consistent with the presence of migmatites and the lack of coeval intrusive granitic plutons (e.g. Ayres and Černý, 1982; Lentz, 1996,

498 1991; Lumbers, 1964; Masson and Gordon, 1981), or (ii) from the differentiation of a melt 499 segregated from a granite at the end of fractional crystallization (Ayres and Černý, 1982; 500 Masson and Gordon, 1981). 
The main features of the LREE-rich PGD from the Lac Okaopéo region obtained in

502 this study have been summarized in Table 6. They are discordant to the foliation of their host

503

504

505

506

507

508

509 rocks and present magmatic textures with no macroscopic nor microscopic evidence for solidstate deformation (Figs. 5-7, 8a, d, 11a-c). All of these PGD, to the noticeable exception of one (13-AE-2149 PGD), are steep-dipping dykes with limited diffuse contacts and no interconnection with leucosome (Figs. 5-7) suggesting they are intrusive into the Paleoproterozoic to Mesoproterozoic Plus-Value paragneisses and Bardoux and Castoréum metaplutonic suites, in a late- to post-tectonic regime, as other REE-rich Grenvillian granitic pegmatites (Ercit, 2005; Lentz, 1996, 1991).

The 13-AE-2149 PGD is a shallow-dipping dyke connected to a network of concordant/discordant veins to the foliation of its host layered mangerite (Figs. 5b, 7e-f) suggesting a distinct and shallower source, and/or a different stress regime. The diffuse contact at its lower contact (Fig. 7g) emphasizes a different petrogenetic process which might have involved syn-crystallization fluid expulsion.

Formation of an orogenic plateau between ca. 1080-1050 Ma has been proposed to be related to ductile lateral flow of the orogenic root beneath the ABT at the base of the Orogenic Lid (Fig. 1b, Rivers, 2008). Late-Ottawan gravitational collapse is inferred to have started in the central Grenville Province by ca. 1065 Ma (Rivers and Schwerdtner, 2015; Soucy La Roche et al., 2015) and to have been completed by ca. 1020 Ma in the western part of the Grenville Province, as evidenced by the reworking of the ABT as an extensional shear zone (Ketchum et al., 1998; Rivers, 2008; Rivers et al., 2012). In the central Grenville, normal shear-sense indicators in a 1015 Ma granite (Indares et al., 2000) in the MIZ and the intrusion of mafic to intermediate magmatic rocks, such as the ca. 1015 Ma Okaopéo Plutonic Suite (Fig. 3) that crosscuts the Ottawan metamorphic fabrics, have been attributed to a phase of crustal extension compatible with this model (e.g. Augland et al., 2015; Indares et al., 2000). 
526 Following the poor tectonic record from ca. 1020 to 1005-1000 Ma, the Rigolet orogenic 527 phase at ca. 1005-980 Ma, marked by the deformation and metamorphism of the 528 Parautochthonous Belt structurally below the ABT, is interpreted to represent a short-lived 529 crustal thickening event (e.g. Dunning and Indares, 2010; Jordan et al., 2006; Lasalle et al., 530 2013). U-Pb dating on magmatic monazite grains from two PGD of the Lac Okaopéo region

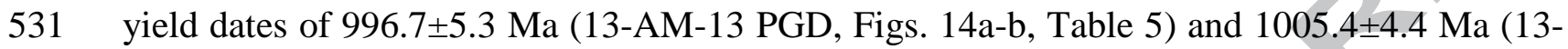
532 TC-5008 PGD, Fig. 14c, Table 5) (see section 7 for details) that are comparable within uncertainty. According to the lack of corrosion of the monazite grains, their oscillatory zoning with no recrystallized domains or their unzoned character, these ca. 1005-1000 Ma concordant dates are interpreted as reflecting their igneous crystallization ages (Crowley et al., 2008) and are therefore attributed to post-Ottawan peak of metamorphism corresponding to the initiation of the Rigolet orogenic phase. These emplacement ages are consistent (i) with the discordant contacts of the dykes to the foliation of their hosts (Figs. 5, 6b, 7c, e-f) and (ii) with the magmatic textures with no evidence for a solid-state deformation nor interconnection with leucosomes (Figs. 6-7, 8a, d, 11a-c). These features suggest a post-tectonic and 541 metamorphic intrusion of the PGD relative to the paragneisses and the metaplutonic 542 complexes of the Allochthonous Belt they intrude and which were affected by the Ottawan 543 orogenic phase (Augland et al., 2015; Moukhsil et al., 2014). This timing of emplacement is 544 similar to the late- to post-Grenvillian Orogeny age of pegmatitic bodies in the western 545 Grenville Province (Fowler and Doig, 1983; Lentz, 1996, 1991, Lumbers, 1979, 1964).

\subsection{Potential sources of the LREE-rich PGD from the Lac Okaopéo region}

In granitic pegmatite fields reported in the literature, e.g. in Cap de Creus 548 (northeastern Spain, Alfonso and Melgarejo, 2008; Druguet et al., 2014; Van Lichtervelde et 549 al., 2016) or in Gatumba (central Rwanda, Hulsbosch et al., 2014; Melcher et al., 2015), the 550 closest bodies from the sources (usually a granite) (i) are the least evolved, and (ii) contain 
biotite but no muscovite nor rare-element minerals (i.e. $\mathrm{Li}, \mathrm{B}, \mathrm{Be}, \mathrm{Rb}, \mathrm{Sn}, \mathrm{Nb}-\mathrm{Ta}$... e.g.

552 Hulsbosch et al., 2014; London, 2016, 2008) or REE mineralization (e.g. Ercit, 2005). In the

553

554

555

556 case of the PGD from the Lac Okaopéo region, the ubiquitous presence of biotite in all the investigated dykes with no muscovite nor other rare elements minerals than monazite or allanite and zircon suggests that they do not represent the last melts that differentiated from the source.

The intrusive contacts of the PGD (Figs. 5, 6b, 7c) and the lack of textural continuity between the PGD and the leucosomes of the host rocks (except for the 13-AE-2149 dyke), are pointing to an origin from a deeper-seated source. This interpretation is corroborated by their emplacement age during the early Rigolet orogenic phase (ca. 1.0 Ga) in host rocks that have recorded deformation and metamorphism during the Ottawan orogenic phase. Furthermore, their pronounced peraluminous signatures (Fig. 13a) are not compatible with a magma derived from the fractionation of the late-Ottawan mafic to intermediate Plutonic Suites of the Lac Okaopéo region, nor of the undated metaluminous volcanic arc granite Céline Plutonic Suite (Augland et al., 2015; Moukhsil et al., 2009, 2013a, 2014).

Jannin et al. (In press) documented that partial melting at a lower structural level than our study area was initiated at least from ca. $1002 \mathrm{Ma}$ at high-pressure in the presence of garnet with pegmatite emplacement taking place between 993 down to possibly 961 Ma. These results confirm that the Parautochthonous Belt experienced the Rigolet crustal thickening phase under granulite facies metamorphism (up to ca. $15 \mathrm{kbar}$ and $850^{\circ} \mathrm{C}$ between ca. 1005-980 Ma, Jordan et al., 2006), i.e. conditions that are favorable for the partial melting of the Parautochthonous Belt and coeval with the emplacement of the PGD. Nb/Ta ratios of the PGD from the Lac Okaopéo region are very high (ranging from 34 to 58, Fig. 13e, Table 2) and are associated with low (except for the 13-AE-2149 dyke) $\mathrm{Nb}$ and $\mathrm{Ta}$ contents (up to 21 and 0.40 respectively, Table 2). Such low values are consistent with the lack of Nb-Ta- 
576 bearing minerals in the PGD, and associated with high $\mathrm{Nb} / \mathrm{Ta}$ are consistent with high-

577 temperature partial melting resulting in a total consumption of biotite from the protolith and

578 the formation of Ti-oxides in the residue that are preferential hosts for $\mathrm{Nb}$ and $\mathrm{Ta}$ and 579 preferentially fractionate the latter (Stepanov et al., 2014). Phase equilibria modeling of 580 metapelite such as those of the Knob Lake Group indicates that a common partial-melting 581 reaction in high-pressure granulite is $\mathrm{Bt}+\mathrm{Pl} \pm \mathrm{Ky}=\mathrm{Liq}+\mathrm{Grt}+\mathrm{Kfs}+\mathrm{Qtz}+\mathrm{Rt}$ (Gervais and 582 Crowley, 2017). In addition to producing leucosome with zircon depleted in HREE because of 583 their sequestration in garnet, such as those in leucosome of the Parautochthonous Belt (Jannin 584 et al., In press), the growth of peritectic rutile associated with this reaction should produce 585 melt with the $\mathrm{Nb}$-Ta features observed in the investigated PGD. the metaluminous signature of the western Grenvillian REE-rich granitic pegmatites reported by Lentz (1996) (Fig. 13a, Table 2) and is compatible with their derivation by partial melting of a metasedimentary unit (e.g. Chappell and White, 2001; Cuney, 2014; White and Chappell, 1977). The high $\mathrm{La}_{\mathrm{N}} / \mathrm{Yb}_{\mathrm{N}}$ ranging from 784 to 938 (monazite-bearing PGD) and from 261 to 619 (13-TC-5072 and 13-FS-1202 allanite-bearing PGD) suggest that these dykes represent melts segregated from a molten crustal component enriched in a HREE-bearing phase, most probably garnet as it is very common in paragneisses especially in those from the Knob Lake

594 Group of the Gagnon Terrane (Bea, 1996; Hönig et al., 2014; Jordan et al., 2006). These 595 features are consistent with the lack of evidence for coeval kilometric scale granitic intrusive 596 body at this stage of the Grenvillian Orogeny and with the results of the great majority of studies dealing with Grenvillian REE-rich granitic pegmatites (e.g. Ercit, 2005; Lentz, 1996, 1991). In addition, it brings evidence that REE-rich granitic pegmatites do not necessarily derive from the fractionation of a granitic intrusive body and that they may be metamorphic in 600 origin as it is proposed by default, especially in the Grenville Province, because of the lack of 
601 an exposed coeval granitic intrusive body (Ercit, 2005). Even though the timing of 602 emplacement and field relationships of the dykes are in favor of a source belonging to the 603 Parautochthonous Belt, whether the molten paragneisses that led to the formation of these 604 dykes belong to the deep Allochthonous (Plus-Value Complex, Figs. 2-3, Moukhsil et al., $6052014,2012)$ or to the Parautochthonous Belt (Knob Lake Group of the Gagnon Terrane, Fig. 606 2, e.g. Rivers, 2008) remains an open question.

The 13-AE-2149 allanite-bearing PGD displays quite different features when

608 compared to other PGD such as (i) a shallow-dipping and diffuse contact (Figs. 5b, 7g), (ii) higher $\mathrm{Nb}$ and $\mathrm{Ta}$ contents of 132 and $3.20 \mathrm{ppm}$ respectively (Table 2), (iii) a weakly peraluminous character (ASI of 1.08, Fig. 13a, Table 2), and (iv) a much lower $\mathrm{La}_{\mathrm{N}} / \mathrm{Yb}_{\mathrm{N}}$ of 28 (Fig. 13b, Table 2). These features suggest its possible derivation by differentiation of a lateOttawan garnet/rutile-poor source (Bea, 1996; Hönig et al., 2014; Stepanov et al., 2014) such as the ca. 1015 Ma Okaopéo Plutonic Suite (high-alkalic mangerite \pm gabbro \pm syenite) and Sabot Mangerite (Augland et al., 2015; Moukhsil et al., 2014), combined with latecrystallization fluid release and/or an interaction with its pre-Grenvillian host metamangerite during its intrusion.

\subsection{Unusual petrogeochemical characteristics of the LREE-rich PGD from the Lac}

\section{Okapéo region}

Previous studies have shown that Grenvillian granitic pegmatites are dominated by quartz $+\mathrm{K}$-feldspar+plagioclase \pm a ferromagnesian phase, completed with a variety of other major and minor phases (e.g. pyroxene, amphibole, biotite, titanite, magnetite, sulfides, allanite, zircon, garnet, monazite, pyrochlore-group minerals and U-Th phases, Ercit, 2005; Fowler and Doig, 1983). Grenvillian granitic pegmatites commonly host REE together with other metals such as U-Th, Nb-Ta, Y, Ti, Zr, Be, Mo, P, Pb, F, with no REE-only mineralization described in these occurrences. The mineralogical assemblage of the PGD 
626 from the Lac Okaopéo region is dominated by quartz+K-feldspar+plagioclase+biotite, as 627 proposed by Ercit (2005), Ford (1982) and Lentz (1996, 1991), and is completed with zircon 628 and monazite or allanite (Figs. 8-12, Tables 3 and 4). No complementary rare-element 629 minerals have been recognized in the PGD of the Lac Okaopéo region, except for the late but 630 micrometric Th-U( \pm REE) silicates (Fig. 8c) and the Ca \pm REE silicates or carbonates (Fig. 631 11e-f) identified in the monazite- and allanite-bearing PGD, respectively, and that represent a 632 negligible part of the whole rock. The accessory phases assemblages, even if not uncommon 633 in worldwide abyssal class pegmatitic bodies (Ercit, 2005), is less diverse than for the rest of 634 the LREE-enriched Grenvillian PGD (Ford, 1982; Lentz, 1996, 1991). Accordingly, the PGD 635 from the Lac Okaopéo region represent the first evidence of magmatic REE-only 636 mineralization in this region.

Monazite and allanite crystals from the PGD investigated in this study are monazite(Ce) and allanite-(Ce) and generally display a core to rim zoning (Figs. 9, 10a, c, 11b, d, Tables 3-4). Monazite crystals from the two investigated PGD present a dominant substitution expressed by the huttonite end-member that is consistent with the concurrent evolution of Th and REE contents (13-AM-13 and 13-TC-5008, Figs. 10b and d, 13c, e.g. Spear and Pyle, 2002). Monazite from the 13-TC-5008 PGD are rather homogeneous (Figs. 9d-f, 10c-d) whereas oscillatory zoned monazite from the 13-AM-13 PGD are characterized by a gradient 644 trending towards monazite-(La) from $\operatorname{LREE}(\mathrm{Ce})$-rich cores to Th-Si-rich rims (Figs. 9a-c, 645 10a-b, Table 3). This suggests an evolution of the melt composition during crystallization 646 from LREE-rich towards Th-Si-rich most probably related to the crystallization of zircon, the 647 only LREE-poor/Th-Si-bearing phase present in the dykes (e.g. Bea, 1996; Hanchar et al., 648 2001). Its crystallization would generate a LREE-rich/Th-Si-poor residual melt, allowing the 649 preferential incorporation of LREE into the monazite lattice and a relatively LREE650 impoverished/Th-Si-enriched residual melt after zircon growth is completed. In contrast, 
651 allanite crystals from the 13-TC-5072 and the 13-FS-1202 PGD display distinct textures.

652 Those from the former show oscillatory zoned cores $\left(A \ln _{1}\right)$ corroded by overgrowths $\left(A \ln _{2}\right.$,

653 Fig. 11b) with stable compositions (Fig. 12a, Table 4). This is most probably related to a new 654 magmatic pulse and not to a significant change in the melt composition. Allanite phenocrysts 655 from the latter however show inner patchy and not oscillatory zoning suggesting a random 656 organization between $\operatorname{LREE}(\mathrm{Ce})$-rich and Fe-Ca-LREE(Ce)-rich zones (Fig. 11d, Table 4).

657 This points to more complex petrogenetic processes than successive growths associated with 658 distinct magmatic pulses. However, a compositional change is recorded in the Fe-poor and in 659 the $\mathrm{Si}$-rich/LREE-poor alteration rims that are expressed on every allanite phenocrysts from 660 the 13-TC-5072 (Fig. 11b) and the 13-FS-1202 (Figs. 11d-e) PGD, respectively (Table 4). 661 According to the lack of corrosion of previous zones associated with no changes in the 662 euhedral shape of the grains, its association with the late-sericitization of feldspar (Fig. 11a, c) 663 and formation of late-Ca \pm REE carbonates or silicates veinlets (Fig. 11e-f), this alteration is

664 most likely related to magmatic-hydrothermal transition processes. In summary, monazite 665 crystals would record the fractionation of zircon during the course of melt crystallization of 666 paragneisses-hosted PGD marked by syn-zircon growth LREE-rich/Th-Si-poor monazite 667 cores and post-zircon growth LREE-poor/Th-Si-rich zones. In contrast, allanite phenocrysts 668 do not allow to discuss magmatic fractionation but offer insights on the magmatic669 hydrothermal transition associated with the formation of allanite alteration rims coeval with 670 late veinlets of carbonates or silicates and most probably with feldspar sericitization.

The empirical relation of monazite in paragneisses-hosted PGD and allanite in 672 metaplutonic-hosted PGD might reflect either (i) an initial geochemical difference between 673 the two granitic series, and/or (ii) interactions of the melt with different rocks during ascent 674 and/or at emplacement level. On the one hand, the former hypothesis is strengthened by (i) the 675 positive correlation between the $\mathrm{P}_{2} \mathrm{O}_{5}, \mathrm{CaO}$ and the $\Sigma \mathrm{REE}$ contents (Fig. 13f) in monazite- 
bearing PGD, unlike in allanite-bearing, and (ii) the positive correlation between the $\mathrm{Fe}_{2} \mathrm{O}_{3}$

677

678

679

680

681

682

683

684

685

686

687

688

689

690

691

692

693

694

(total), $\mathrm{MgO}$ and the $\mathrm{REE}$ contents in allanite-bearing PGD (Fig. 13g). On the other hand, the hypothesis of an interaction between melts and surrounding rocks is supported by the empirical relationship (i) between monazite-bearing PGD and wide outcropping areas of metasediments ( 3 over 4 PGD hosted in the Plus-Value Complex), and (ii) between allanitebearing PGD and metaplutonic complexes (2 over 3 PGD hosted in the Bardoux and Castoréum Plutonic Suites) (Figs. 3, 6-7). These suggest that the crystallization of monazite and allanite could be related to interactions of the granitic melt (i) with the more sodic metasedimentary host of the Plus-Value complex for the former, and conversely (ii) with the more calcic igneous rocks of the Bardoux and Castoreum suites for the latter. This hypothesis is consistent with the locally diffuse contact of the 13-TC-5008 monazite-bearing PGD (Fig. 6c) and the very diffuse contact at the lower contact of the 13-AE-2149 allanite-bearing PGD (Fig. 7g). Such a model has been proposed for granitic pegmatites from the southwestern Grenville Province and is designated as "hybridization" by Lentz (1996, 1991), who evidenced bi-metasomatic exchange processes leading to $\mathrm{Ca}, \mathrm{Fe}, \mathrm{Mg} \pm \mathrm{Ti}$ enrichment in the melts and to the crystallization of titanite and allanite. However, (i) the lack of macroscopic mineralogical reaction zone at the contact of most of the dykes with their host rocks, and (ii) the close geographical association of the 13-TC-5008 monazite-bearing and the 13-AE-2149 allanite-bearing PGD (Fig. 3), make the hypotheses of a control of the mineralization by deep interaction between the magma and rocks of distinct chemical composition unlikely. In addition, both monazite- and allanite-bearing samples display a similar positive correlation between the $\mathrm{Na}_{2} \mathrm{O}$, the $\mathrm{CaO}$ and the $\Sigma$ REE contents (Fig. 13d) suggesting that the hypothesis of an initial geochemical difference between the two granitic series is most likely. Therefore we propose that the control of the mineralization either as monazite or allanite observed in the PGD from the Lac Okaopéo may not only be correlated with the activities of $\mathrm{Na}$ and $\mathrm{Ca}$ as 
701

702

703

704

705

706

707

708

709

710

711

712

713

714

715

716

717

718

719

720

721

722

723

724

725

proposed in the models of Berger et al. (2009) and Budzyń et al. (2011) but by the initial CaO and $\mathrm{P}_{2} \mathrm{O}_{5}$ contents, and the $\mathrm{Fe}_{2} \mathrm{O}_{3}$ (total) and $\mathrm{MgO}$, respectively. Exception is the 13-AE-2149 dyke emplaced in an intermediate host metamangerite with a diffuse lower contact, and that displays a weakly peraluminous character (ASI of 1.08, Fig. 13a, Table 2) that is intermediate between the other PGD investigated in this study and those reported by Lentz (1996). This lower peraluminous signature may reflect an interaction of the dyke with its host during its emplacement, as proposed by Lentz (1996) for western Grenvillian granitic pegmatites.

The weak to strong peraluminous character associated with $\mathrm{P}_{2} \mathrm{O}_{5}$ contents of $0.02-0.40$ wt.\% (Fig. 13f, Table 2) of the PGD from the Lac Okaopéo region correspond to the peraluminous intermediate phosphorous serie defined by Linnen and Cuney (2005). It contrast with the metaluminous Grenvillian LREE-enriched granitic pegmatites of Lentz (1996) (Fig. 13a) and with REE-enriched granitic pegmatites reported elsewhere that are ascribed to alkaline intrusive (Dill, 2010, 2015; Ercit, 2005; London, 2016). Allanite is a major LREE carrier in granitoids with ASI below 1.2 (Bea, 1996) and in LREE-enriched granitic pegmatites from the abyssal class, usually ascribed to metaluminous to subaluminous compositions (Ercit, 2005; Ford, 1982; Lentz, 1996, 1991), i.e. not in strongly peraluminous melt. In the PGD from the Lac Okaopéo region, allanite is hosted in three metaplutonic hosted PGD, two of them displaying ASI ranging from 1.18 to 1.35 (13-TC-5072 and 13-FS-1202 PGD respectively, Table 2) that are not compatible with the formation of allanite. In contrast, the presence of monazite in paragneisses-hosted PGD with ASI ranging from 1.19 to 1.36 (Table 2) is consistent with its expression as a major and widespread LREE-carrier in a variety of granitoids especially in peraluminous granite and abyssal granitic pegmatites (Bea, 1996; Ercit, 2005; Linnen and Cuney, 2005; Montel, 1993; Rapp and Watson, 1986), but its sole presence as LREE-bearing phase in PGD is shown for the first time in the Grenville Province. 
The monazite- and allanite-bearing PGD from the Lac Okaopéo region are generally more concentrated in REE and more fractionated in LREE over HREE than those of the most enriched samples of Lentz (1996), with SREE between 1418 to 7048 ppm (monazite-bearing PGD) and between 2393 to 9242 ppm (13-TC-5072 and 13-FS-1202 allanite-bearing PGD), associated with $\mathrm{La}_{\mathrm{N}} / \mathrm{Yb}_{\mathrm{N}}$ up to 938 (Fig. 13b, Table 2). The $\Sigma$ REE content of PGD from the Lac Okaopéo region increases with (i) decreasing $\mathrm{Eu} / \mathrm{Eu}^{*}$ anomaly from 0.72 down to 0.12 (Fig. 13b, Table 2), and (ii) with increasing $U$ and Th contents (Fig. 13c), Th being much more concentrated than $\mathrm{U}(\mathrm{Th} / \mathrm{U}$ ratio between 25 and 74, Table 2). Both features are consistent with the increasing proportion of REE-bearing phases relative to major minerals that represent sinks for Eu (e.g. Bea, 1996; London, 2008). The U and Th contents increase more rapidly with $\Sigma$ REE in monazite-bearing than in allanite-bearing dykes (Fig. 13c) as marked by the formation of $\mathrm{ThO}_{2}$-rich monazite relative to allanite (Tables 3-4).

The monazite- and allanite-bearing PGD present unusual and some distinct geochemical trends (Fig. 13). The high $\mathrm{Zr} / \mathrm{Hf}$ ratio (Fig. 13e) associated with high contents of $\mathrm{Zr}$ and $\mathrm{Hf}$ (up to 1480 and $41.5 \mathrm{ppm}$ respectively, Table 2) and the very low contents of $\mathrm{Nb}$ and Ta of the PGD (Table 2) is characteristic of alkaline melts (Linnen and Cuney, 2005; Linnen and Keppler, 2002; Zaraisky et al., 2009). The quite stable $\mathrm{Zr} / \mathrm{Hf}$ with increasing $\Sigma$ REE is also a characteristic feature of alkaline melts in which the high zircon solubility prevents the fractionation of $\mathrm{Zr}$ over $\mathrm{Hf}$ associated with zircon growth (Ellison and Hess, 1986; Linnen, 1998; Linnen and Cuney, 2005; Linnen and Keppler, 2002; Zaraisky et al., 2009). The contrasting behavior of the $\mathrm{Nb} / \mathrm{Ta}$ ratio in monazite- and allanite-bearing PGD, with increasing $\mathrm{Nb} / \mathrm{Ta}$ ratio and $\Sigma \mathrm{REE}$ content in monazite-bearing and decreasing $\mathrm{Nb} / \mathrm{Ta}$ ratio with increasing $\Sigma$ REE content in allanite-bearing PGD (Fig. 13e), suggest either distinct (i) magmatic processes, or (ii) fractionation of $\mathrm{Nb}$ over Ta associated with distinct sources or (iii) with the crystallization of monazite over allanite. The former hypothesis is unlikely 
according to the lack of $\mathrm{Nb}$ and Ta minerals in the dykes. Accordingly, the whole-rock geochemistry of the REE-rich PGD from the Lac Okaopéo region display contrasting signatures with (i) major elements characteristics of intermediate phosphorous peraluminous granites (e.g. Linnen and Cuney, 2005), and (ii) trace elements (Zr-Hf-Nb-Ta and the REE) enrichment and fractionation more akin to a peralkaline signature of the melts (e.g. Ellison and Hess, 1986; Linnen, 1998; Linnen and Cuney, 2005; Linnen and Keppler, 2002; Zaraisky et al., 2009).

\subsection{LREE-rich PGD from the Lac Okapéo region in the granitic pegmatite} classification scheme

The PGD from the Lac Okaopéo region display peraluminous signatures (Fig. 13a, Table 1), are LREE enriched (Fig. 13b) and are composed of a quartz+Kfeldspar+plagioclase+biotite (for major minerals, Figs. 8a, d, 11a-c) with either monazite or allanite and ubiquitous zircon (Figs. 8a-c, 11b-f). Mineralized granitic pegmatites displaying a peraluminous signature usually belong to the LCT family (Černý et al., 2012; Černý and Ercit, 2005; Ercit, 2005; London, 2005, 2008; Martin and De Vito, 2005). Even though the seven PGD described in this paper are peraluminous, they do not share any other characteristic of this family since none of them contain any muscovite, nor Li-, Cs- or Ta-minerals, nor tourmaline or beryl and are not enriched in $\mathrm{Rb}, \mathrm{Ga}$ or $\mathrm{Sn}$. In addition, their trace elements geochemistry is more akin to alkaline melts (e.g. Linnen and Cuney, 2005; Linnen and Keppler, 2002). In the classical classification scheme, the NYF family contains pegmatitic bodies derived from alkaline intrusive bodies and are enriched in $\mathrm{Nb}, \mathrm{Y}, \mathrm{F}, \mathrm{Be}, \mathrm{Ti}, \mathrm{Sc}, \mathrm{Zr}$ with LREE concentrations up to 100 to 800 times chondritic and little depletion in HREE (Černý et al., 2012; Černý and Ercit, 2005; Ercit, 2005; London, 2005, 2008). PGD investigated from the Lac Okaopéo region do not contain any minerals hosting the usual rare-metals of the NYF family, show an LREE enrichment from over 1,000 to almost 10,000 times the chondritic 
value (Fig. 13b), a strong depletion of HREE and, for six of them (exception is the 13-AE2149 PGD) are most probably derived by partial melting of a deeper-seated metasedimentary source. Therefore, they are not characteristic of the NYF family neither.

Ercit (2005) reviewed the general characteristics of world-wide REE-enriched granitic pegmatites. These are mainly observed in Colorado, Virginia and Northern Carolina (USA), Kola-Karelia and Pribaikal regions, and Aldan Shield (Russia), southern Japan, AntsirabéKitsamby and Ankazobe districts (Madagascar), and finally in the SW Grenville Province, that represents one of the major districts of such REE occurrences (e.g. Ford, 1982; Lentz, 1996, 1991). Ercit (2005) emphasized that REE-enriched granitic pegmatites do not always fall in fields of the previously described granitic pegmatites families (either LCT or NYF) of Černý (1991). However, in the abyssal class, two main types of REE-enriched granitic pegmatites are common: (i) the LREE-enriched that typically host REE as an allanitemonazite and/or uraninite assemblage, and (ii) the (Y,HREE)-enriched that typically host REE assemblage as more complex rare-element assemblages than the previous one (Ercit, 2005). The PGD from the Lac Okaopéo region display $\Sigma$ LREE contents between 1407 and 7435 ppm hosted in either monazite or allanite (Figs. 6f, 7b-d, g, 8a-c, 9-12) and $\Sigma$ HREE contents between 11 and 485 ppm (Fig. 13b, Table 2) and can therefore be ascribed to the LREE-enriched type of Ercit (2005).

According to previous sections of the discussion, the zoned PGD from the Lac Okaopéo region intruded metamorphosed sedimentary units and metaigneous complexes in a post-tectonic setting relative to the structure and metamorphism of their host rocks with no link, for six of them (except for the 13-AE-2149 PGD), to a plutonic body (see sections 8.1. and 8.2.) and therefore correspond to the class of 'pseudopegmatites' proposed by Dill (2016) in its CMS (Chemical composition - Mineral assemblage - Structural geology) classification scheme. The 13-AE-2149 PGD however could derive by differentiation of a late-Ottawan 
801 plutonic suite and would therefore correspond to the 'pegmatite' class of Dill (2016). In

802 addition, according to the same scheme the monazite-bearing PGD are paragneisses-hosted 803 zoned meter-sized (Zr)-LREE quartz-feldspar-biotite pseudopegmatite (monazite), whereas 804 the 13-TC-5072 and the 13-FS-1202 allanite-bearing PGD are metamonzogranite-hosted 805 zoned decimeter- to meter-sized ( $\mathrm{Zr}$ )-LREE quartz-feldspar-biotite pseudopegmatite (allanite) 806 and quartz metamonzodiorite-hosted zoned decimeter- to meter-sized (Zr)-LREE quartz807 feldspar-biotite pseudopegmatite (allanite), respectively. In the same way and according to the 808 its possible derivation from a plutonic source, the 13-AE-2149 allanite-bearing PGD is a 809 metamangerite-hosted zoned centimeter- to meter-sized ( $\mathrm{Zr}$ )-LREE quartz-feldspar-biotite 810 (pseudo)pegmatite (allanite) according to Dill (2016).

\section{Conclusions}

The seven pegmatitic granite dykes (PGD) from the Lac Okaopéo region described in

813 this paper represent new LREE-only occurrences in the central Grenville Province. They

814 intrude paragneisses from the Plus-Value Complex or felsic to intermediate metaplutonic 815 complexes from the Bardoux and Castoréum Plutonic Suites that are part of the 816 Allochthonous Belt of the Grenville Province. These LREE occurrences are undeformed 817 dykes discordant to the foliation of their host rocks with no evidence for interconnection with 818 leucosomes and are thus considered as post-tectonic relative to the structure and 819 metamorphism of their host rocks that recorded the Ottawan orogenic phase. Their 820 peraluminous signature, high $\mathrm{Nb} / \mathrm{Ta}$ ratio and high fractionation of LREE over HREE suggest 821 their derivation by partial melting of metasedimentary units, either belonging to the base of 822 the Allochthonous or to the Parautochthonous Belt. U-Pb dating of magmatic monazite from 823 two of the LREE occurrences yield concordant igneous ages at 996.7 $\pm 5.3 \mathrm{Ma}$ and 1005.4 \pm 4.4 824 Ma that correspond to an emplacement at the initiation of the Rigolet orogenic phase 825 considered to represent a short-lived phase of renewed crustal thickening as recorded by 
deformation and metamorphism of the Parautochthonous Belt between ca. 1005 and 980 Ma.

Further isotopic and geochronological investigations are needed to constrain their derivation either from the Allochthonous or the Parautochthonous Belt.

Field relationships show that monazite host the LREE-mineralization for PGD hosted by paragneisses of the Plus-Value Complex, and that allanite host the LREE-mineralization for PGD hosted by metagranitoids of the Bardoux and Castoréum Plutonic Suites, in both cases without complementary rare-metals minerals. The geochemistry and rare-metals assemblage do not allow to ascribe these PGD to the classical LCT and NYF family. In addition, even if a peraluminous character is marked by the major elements whole-rock geochemistry, the $\mathrm{Zr} / \mathrm{Hf}$ ratio associated with high $\mathrm{Zr}$ and $\mathrm{Hf}$ contents, the very low contents in $\mathrm{Nb}$ and Ta and the very high contents in LREE are more akin to a peralkaline series.

The peraluminous signature of the mineralized PGD contrasts with the typical metaluminous to subaluminous signature of REE-enriched granitic pegmatites reported elsewhere. This peraluminous composition is consistent with the crystallization of monazite(Ce) but is at odd with the presence of allanite-(Ce). This contribution constitutes the first evidence in the Grenville Province of such a monazite-only mineralization hosted in PGD. Further investigations are required to identify the factors controlling the crystallization of allanite in some of these PGD.

\section{Acknowledgements}

The authors would like to thank the Ministère de l'Energie et des Ressources naturelles (Québec) for providing technical and financial support for the field work and analyses. This contribution constitutes a Ministère de l'Energie et des Ressources naturelles du Québec publication n̊8449-2016-2017-04. The authors are grateful to Sandrine Mathieu (SEM), Lise Salsi (SEM) and Olivier Rouer (EMP) (GeoRessources, Nancy) for technical support in 
850

851

852

853

854

providing analytical data on SEM and EMP, to Alexandre Crépon (GeoRessources, Nancy) for their help during field work and to Aurélien Eglinger (GeoRessources, Nancy) for his help in handling geochronological data. The authors also thank Harald G. Dill and an anonymous reviewer for their detailed review that helped to improve the paper, and Franco Pirajno for editorial handling. This work was funded by the Labex Ressources 21 (supported by the French National Research Agency through the national program "Investissements d'avenir", reference ANR-10-LABX-21-LABEX RESSOURCES 21 and the Region Grand-Est. It benefited from the framework of the DIVEX "Rare earth element" research program.

\section{Appendix A: Detailed mapping of the monazite-bearing pegmatitic granite outcrops}

\section{13-AM-07 monazite-bearing pegmatitic granite dyke (PGD)}

The 13-AM-07 monazite-bearing pegmatitic granite dyke (PGD) and REE occurrence is located in the north of the 22K/10 NTS sheet (Fig. 3) and is exposed as a small (a few square meters in surface) and flat lying outcrop (Fig. A-2a). The detailed map of this outcrop is available in the Fig. A-1. 
866

867

868

869

870

871

872

873

874

875

876

877

878

879

880

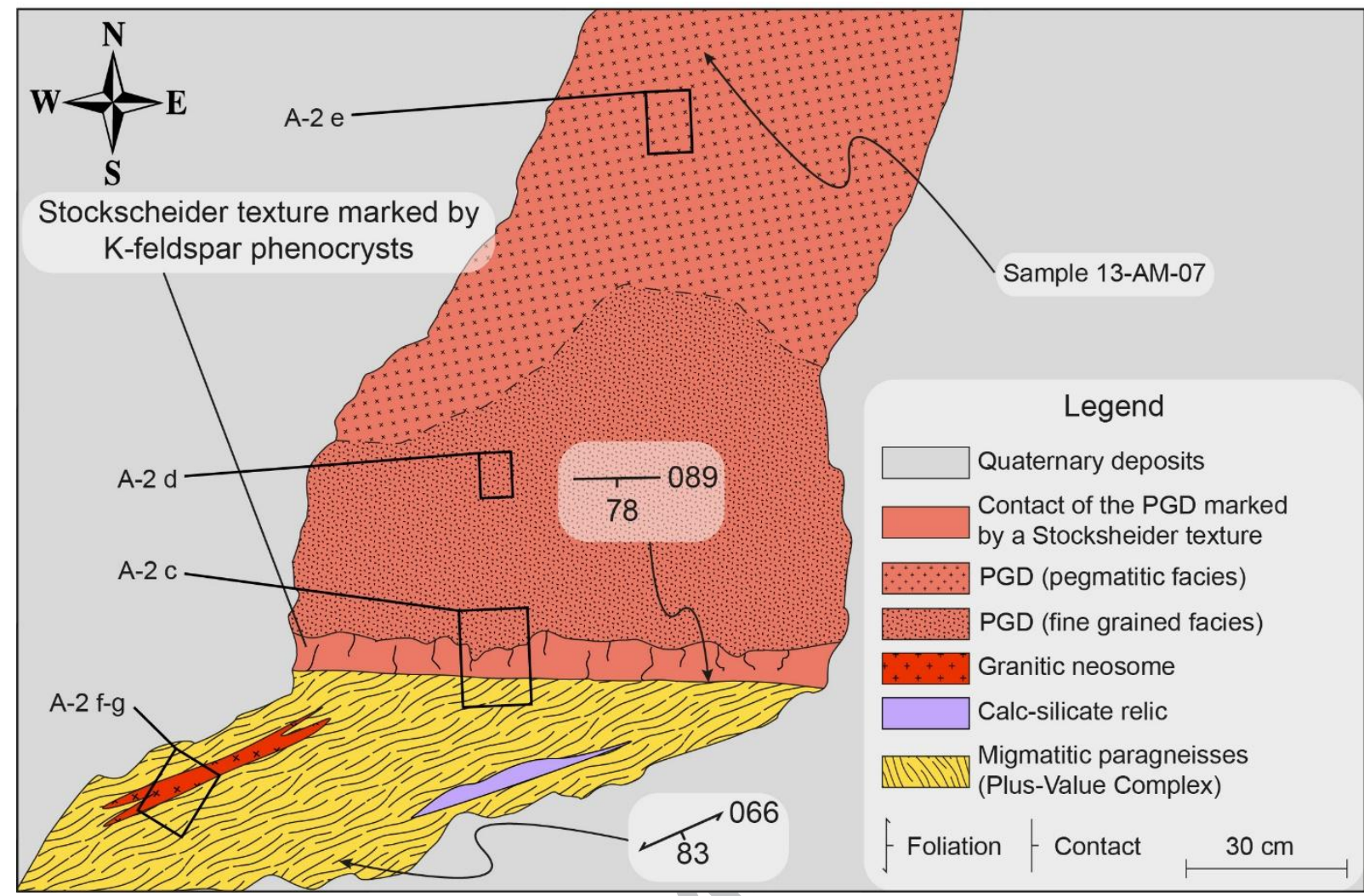

Figure A-1: Detailed map of the 13-AM-07 outcrop made of migmatitic paragneisses from the Plus-Value Complex intruded by a discordant REE-rich pegmatitic granite dyke. Abbreviation: PGD = pegmatitic granite dyke.

The PGD is steep-dipping and discordant to the foliation of the Plus-Value Complex migmatitic paragneisses (Figs. A-2b-c, 5a). The dyke is whitish (Figs. A-2b-e) and is layered parallel to the contact. The discordant contact with the paragneisses is marked by the development of a Stockscheider texture visible in the development of K-feldspar phenocrysts reaching a length of up to $5 \mathrm{~cm}$ (Fig. A-2c). From the contact and towards the core of the dyke, these phenocrysts are in contact with a 20 to $50 \mathrm{~cm}$ wide fine-grained facies (Figs. A-2b and d) grading onto a pegmatitic facies (Figs. A-2b and e) with crystals reaching up to ca. 3 $\mathrm{cm}$ in the center of the dyke.

The host paragneisses from the Plus-Value Complex are migmatitic with granitic \pm garnet-biotite leucosomes that can reach several tens of centimeters in width (Figs. A-2b, f-g). 

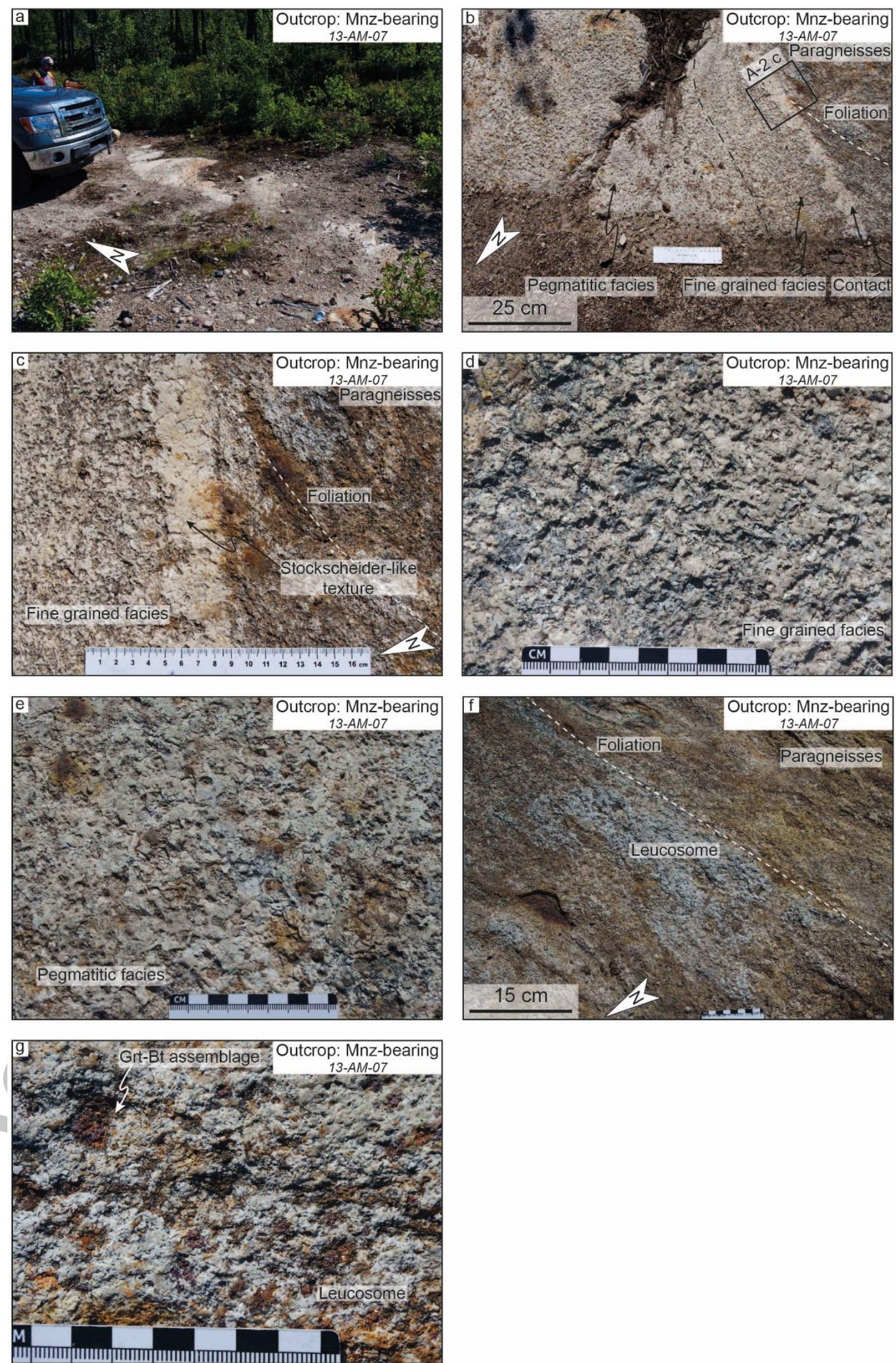

Figure A-2: Photographs of the 13-AM-07 outcrop from the Lac Okaopéo region. a: general view of the 13contact between the pegmatitic granite dyke and the intruded paragneisses marked by the crystallization of 
feldspar from the dyke perpendicular to the contact; $d$ : detailed view of the fine grained facies dominated by feldspar and quartz; e: detailed view of the pegmatitic facies dominated by feldspar and quartz; f: typical facies of the Plus-Value Complex paragneisses showing the importance of leucosomes in this facies; g: mineralogy of the leucosomes from the migmatitic Plus-Value Complex paragneisses. Note the domination of quartz-feldspar in this granitic leucosome, the abundance of the garnet-biotite assemblage expressed as several millimeters crystals and the lack of deformation in these leucosomes. Abbreviations: Bt = biotite; Grt = garnet; Mnz-bearing = monazite-bearing pegmatitic granite dyke.

\section{13-AM-10 monazite-bearing PGD}

The 13-AM-10 monazite-bearing PGD and REE occurrence is located at the south of the 13-AM-07 outcrop, in the north of the 22K/10 NTS sheet (Fig. 3), and is exposed as a steep-dipping outcrop along a gravel road (Fig. A-4a). The detailed map of this outcrop is available in Fig. A-3.

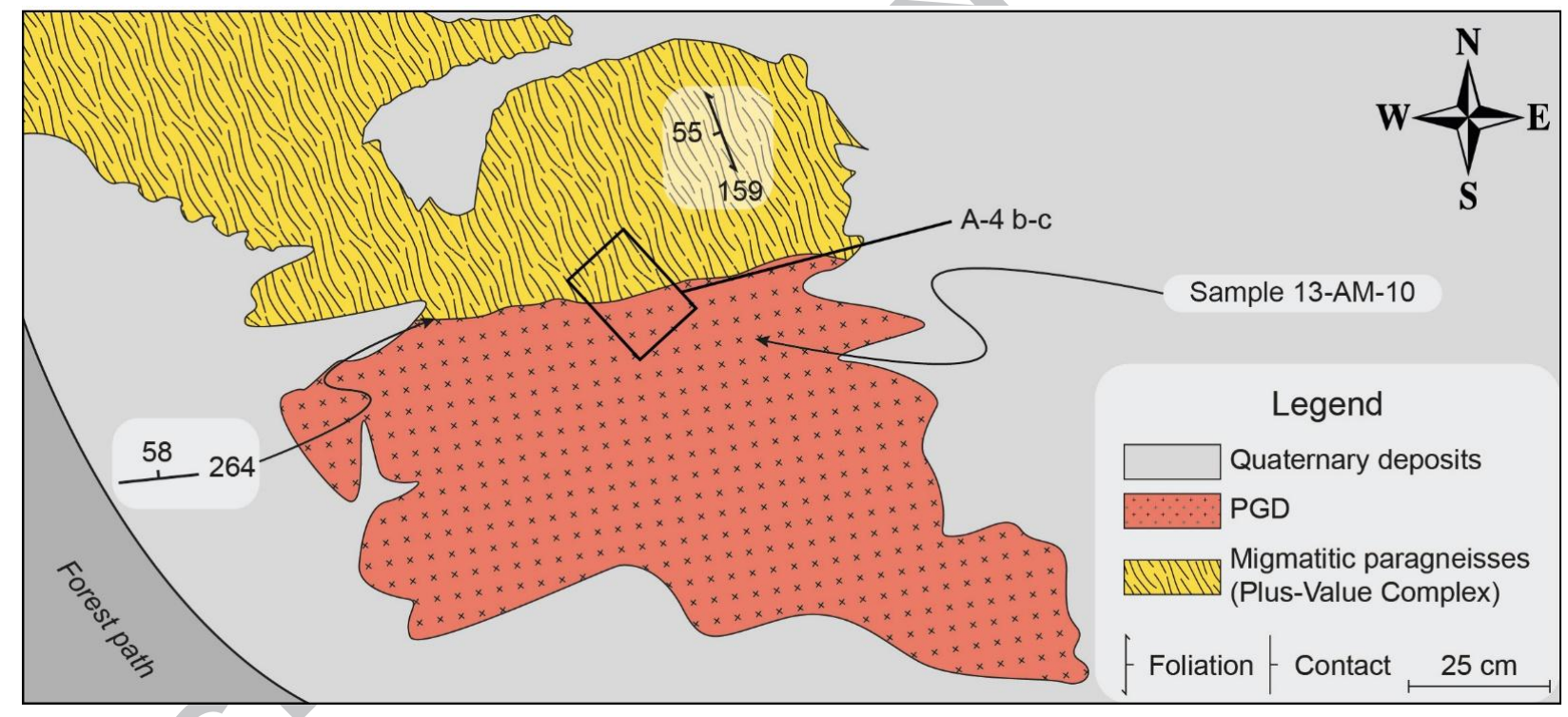

Figure A-3: Detailed map of the 13-AM-10 outcrop made of migmatitic paragneisses from the Plus-Value Complex intruded by a discordant REE-rich pegmatitic granite dyke. Abbreviation: PGD = pegmatitic granite dyke.

The PGD is steep-dipping and discordant to the rusty Plus-Value Complex migmatitic paragneisses (Figs. A-4c, 5a). The contact between the dyke and the host paragneiss is straight but is slightly diffuse (over a few millimeters, Fig. A-4b) and the dyke do not display noticeable facies variations. 

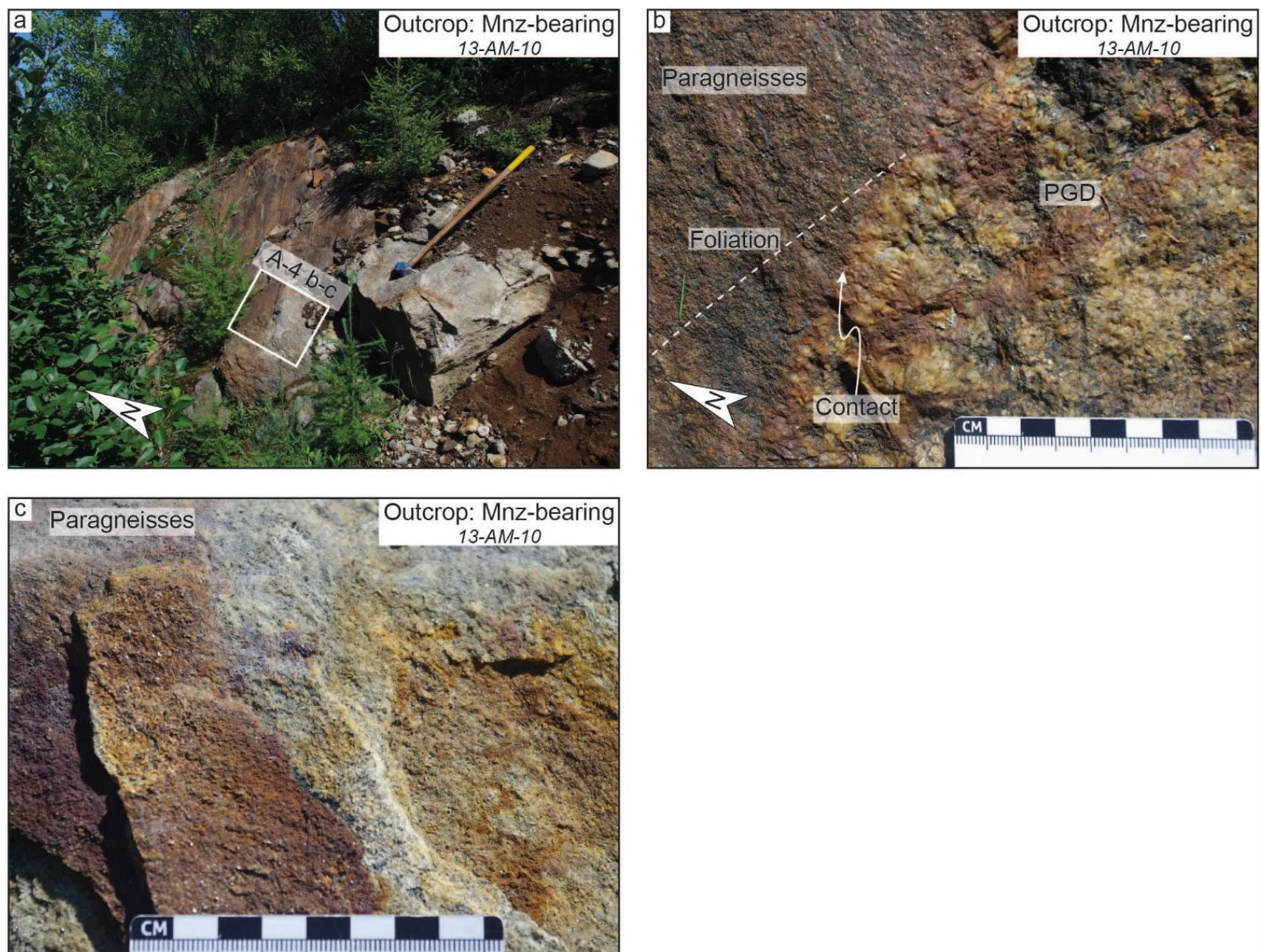

Figure A-4: Photographs of the 13-AM-10 outcrop from the Lac Okaopéo region. a: general view of the 13AM-10 outcrop composed of a pegmatitic granite dyke intruding paragneisses from the Plus-Value Complex. The hammer is ca. $1.2 \mathrm{~m}$ long; $\mathrm{b}$ : detailed view of the relationships between the dyke and the paragneisses. The foliation is not noticeable on this photograph but its general orientation is represented; c: detailed view of the intruded paragneisses. Abbreviation: Mnz-bearing = monazite-bearing pegmatitic granite dyke; PGD = 


\section{11. 13-AM-13 monazite-bearing PGD}

916 The whitish 10 to 20 meters wide 13-AM-13 monazite-bearing PGD and REE

917 occurrence is located to the south of the 13-AM-10 outcrop, in the north of the 22K/10 NTS

918 sheet (Fig. 3), and is exposed as a large flat lying outcrop (Fig. A-6a). The Fig. A-5 proposes

919 the detailed mapping of this outcrop with localization of the samples and of the photographs 920 presented in Fig. A-6. 


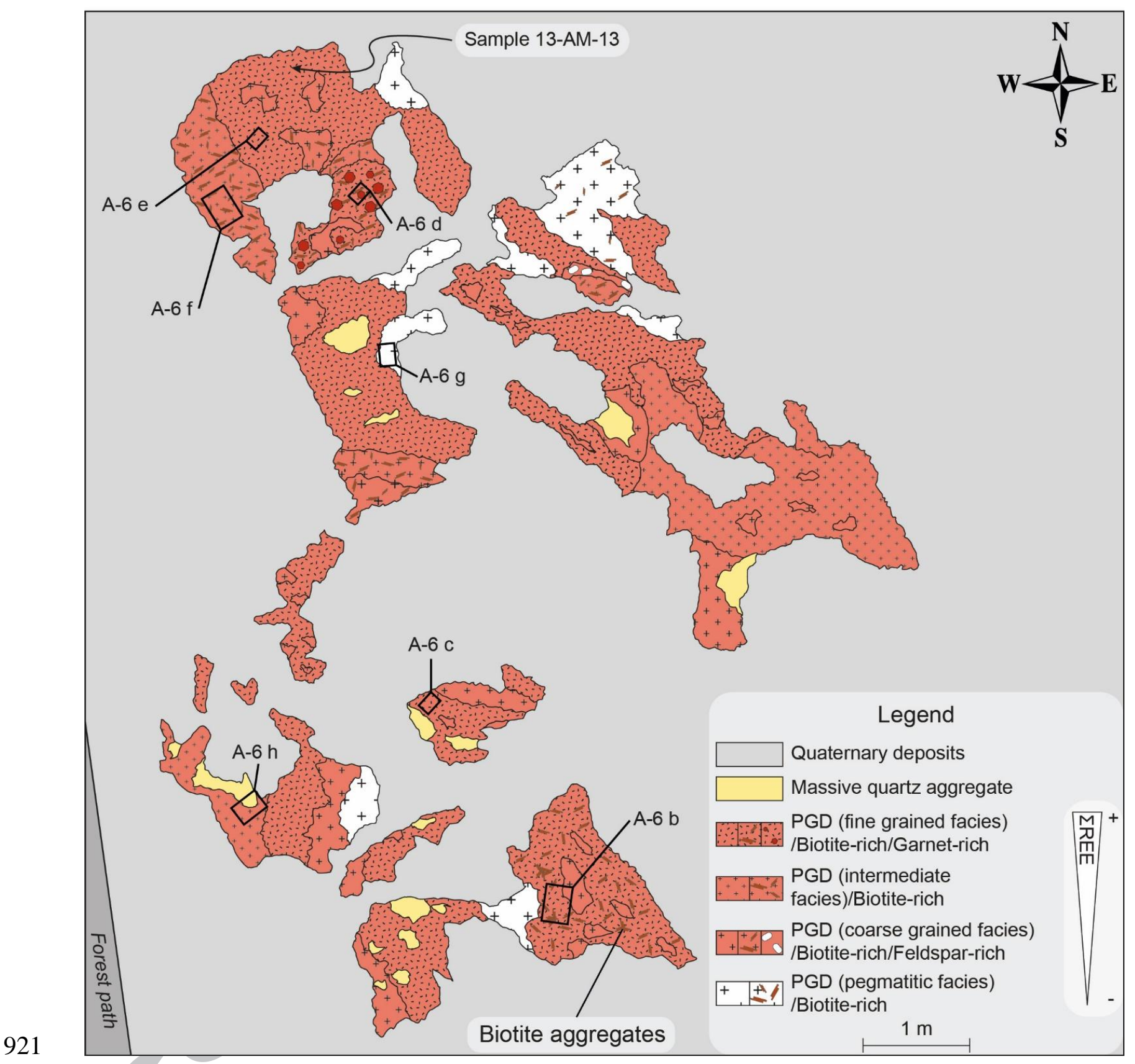

Figure A-5: Detailed map of the 13-AM-13 outcrop made of migmatitic paragneisses from the Plus-Value 922 Figure A-5: Detailed map of the 13-AM-13 outcrop made of migmatitic paragneisses from the Plus-Value
923 Complex intruded by a discordant REE-rich pegmatitic granite dyke. Abbreviation: PGD = pegmatitic granite 924 dyke.

The PGD is steep-dipping and discordant to the foliation of the paragneisses from the

926 Plus-Value Complex (Fig. 5a). The contact between the PGD and the host paragneisses is

927 poorly exposed but the distribution of outcrops suggests that the contact is not straight over several meters. 
930 feldspar-rich facies with minor biotite and garnet (Figs. A-5 and 6b-d). This facies is the main

931 host for the mineralization expressed as sub-euhedral monazite grains (Fig. A-6e). The PGD

932 comprises randomly distributed tens of centimeters to $1 \mathrm{~m}$ large patchy zones characterized by

933 (i) an intermediate quartz and feldspar-rich \pm biotite facies (Figs. A-5, A-6f), (ii) a coarse-

934 grained quartz and feldspar-rich facies with more or less abundant biotite and phenocrysts of 935 feldspar (Fig. A-6b), and (iii) a pegmatitic quartz and feldspar-rich \pm biotite facies (some grains 936 over $5 \mathrm{~cm}$, Fig. A-6g). Locally, up to ca. $20 \mathrm{~cm}$ centimeters wide quartz aggregates are also 937 noticeable but do not seem associated with any of the previous facies (Figs. A-5 and 6h). The 938 transition between two facies is mostly diffuse and difficult to delineate, but it may also be 939 underlined by biotite aggregates (Fig. A-6b). 



Figure A-6: Photographs of the 13-AM-13 outcrop from the Lac Okaopéo region. a: general view of the 13- 
abundance of biotite in the fine grained facies on this photograph is related to the vicinity of the coarse grained facies; c: typical fine grained facies dominated by a quartz+feldspartbiotite assemblage; d: detailed view of a garnet phenocryst in the fine grained facies; e: monazite crystals from the fine grained facies; $f$ : typical intermediate facies composed of a quartz-feldspar-biotite assemblage; g: typical pegmatitic facies essentially composed of a quartz-feldspar-biotite assemblage in which feldspar and biotite crystals can reach over $5 \mathrm{~cm}$; $\mathbf{~}$ : quartz aggregates in the intermediate facies. Abbreviations: $\mathrm{Bt}=$ biotite; Fsp = feldspar; Grt = garnet; $\mathrm{Mnz}$ = monazite; Mnz-bearing = monazite-bearing pegmatitic granite dyke; $\mathrm{Qz}$ = quartz.

\section{13-TC-5008 monazite-bearing PGD}

The 13-TC-5008 monazite-bearing PGD and REE occurrence is located in the north of the 22K/07 NTS sheet (Fig. 3) and is exposed as a large flat lying outcrop (Fig. A-8a). The Fig. A-7 proposes the detailed mapping of this outcrop with localization of the samples and of the photographs presented in Fig. A-8.

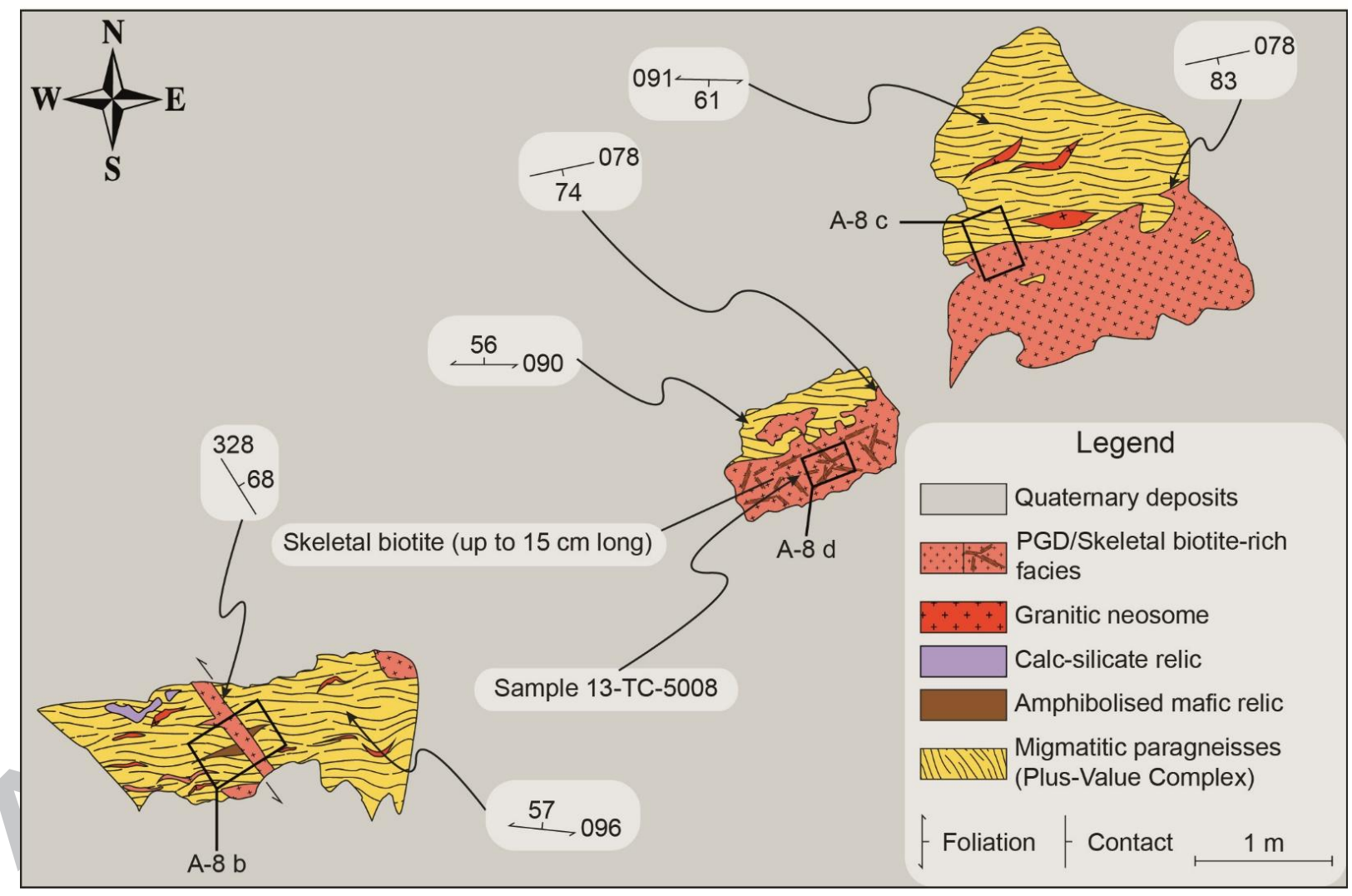

Figure A-7: Detailed map of the 13-TC-5008 outcrop made of migmatitic paragneisses from the Plus-Value Complex intruded by a discordant REE-rich pegmatitic granite dyke. Abbreviation: PGD = pegmatitic granite dyke.

The 13-TC-5008 outcrop displays several showings of a few square meters large area (Figs. A-7, A-8a) made of large or thin (ca. $10 \mathrm{~cm}$ wide, Fig. A-8b) steep-dipping PGD discordant to the foliation of the migmatitic paragneisses of the Plus-Value Complex (Figs. A- 
964 (Figs. A-8b-c). It seems to represent a zone of reactions between the granitic melt and the

965 intruded metasediments as it may be underlined in the PGD by garnet-biotite aggregates (Fig.

966 A-8c).

The few square meters PGD showings and the thin whitish PG dyke do not display

968

969

970

971

any zoning from the contact to their core. However, some patchy zoning made of facies

enriched in skeletal biotite (cluster as arborescent arrangements of up to $15 \mathrm{~cm}$ biotite

crystals, Fig. A-8d) are noticeable and are about a few tens of centimeters wide. The transition

between these patches and the dominant facies is diffuse.
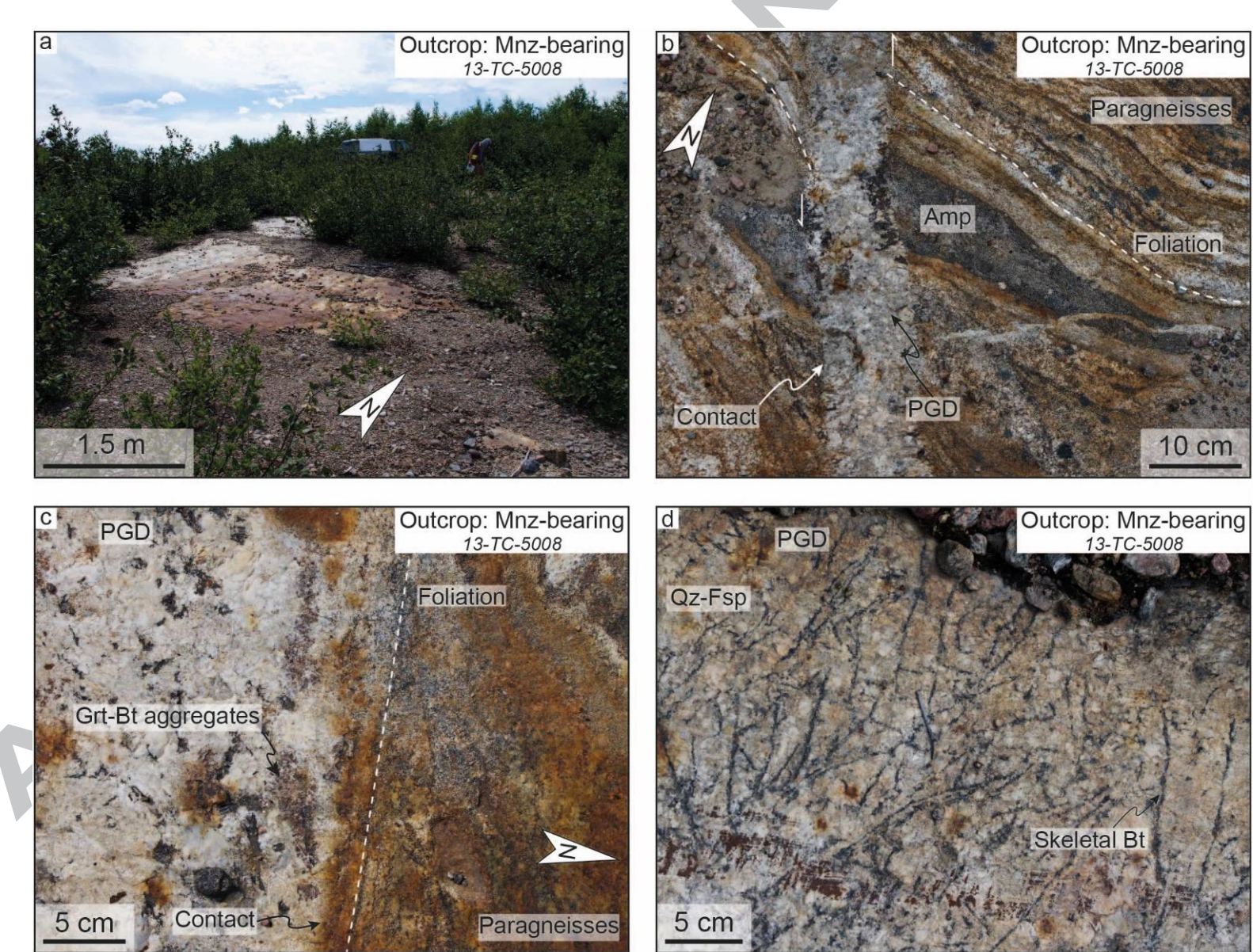

Figure A-8: Photographs of the 13-TC-5008 outcrop from the Lac Okaopéo region. a: general view of the 13-

TC-5008 outcrop composed of a pegmatitic granite intruding paragneisses from the Plus-Value Complex; b: intrusion of a pegmatitic granitic dyke favored by a sinistral shearing that affect both the migmatitic paragneisses from the Plus-Value Complex and the amphibolized mafic relic it contains. The resulting contact is discordant as evidenced by the crosscut foliation of the intruded paragneisses by the dyke; $c$ : locally diffuse contact between the dyke and the intruded paragneisses delineated by garnet-biotite aggregates; $d$ : arborescent textures made by skeletal crystals reaching up to $15 \mathrm{~cm}$ long. Abbreviations: Amp = amphibolized 
983 Appendix B: Detailed mapping of the allanite-bearing pegmatitic granite 984 outcrops

985 13. 13-TC-5072 allanite-bearing pegmatitic granite dyke (PGD)

The 13-TC-5072 allanite-bearing pegmatitic granite dyke (PGD) and REE occurrence

987 is located in the south of the $22 \mathrm{~K} / 10$ NTS sheet (Fig. 3) and is exposed as a large and dome 988 shaped outcrop (Fig. B-2a). The detailed map of this outcrop is available in the Fig. B-1. It 989 consists in numerous straight pinkish (fresh color) PGD (up to 4 m wide, Figs. B-1 and B-2b990 f) intruding a metamonzogranite from the Bardoux Plutonic Suite. 


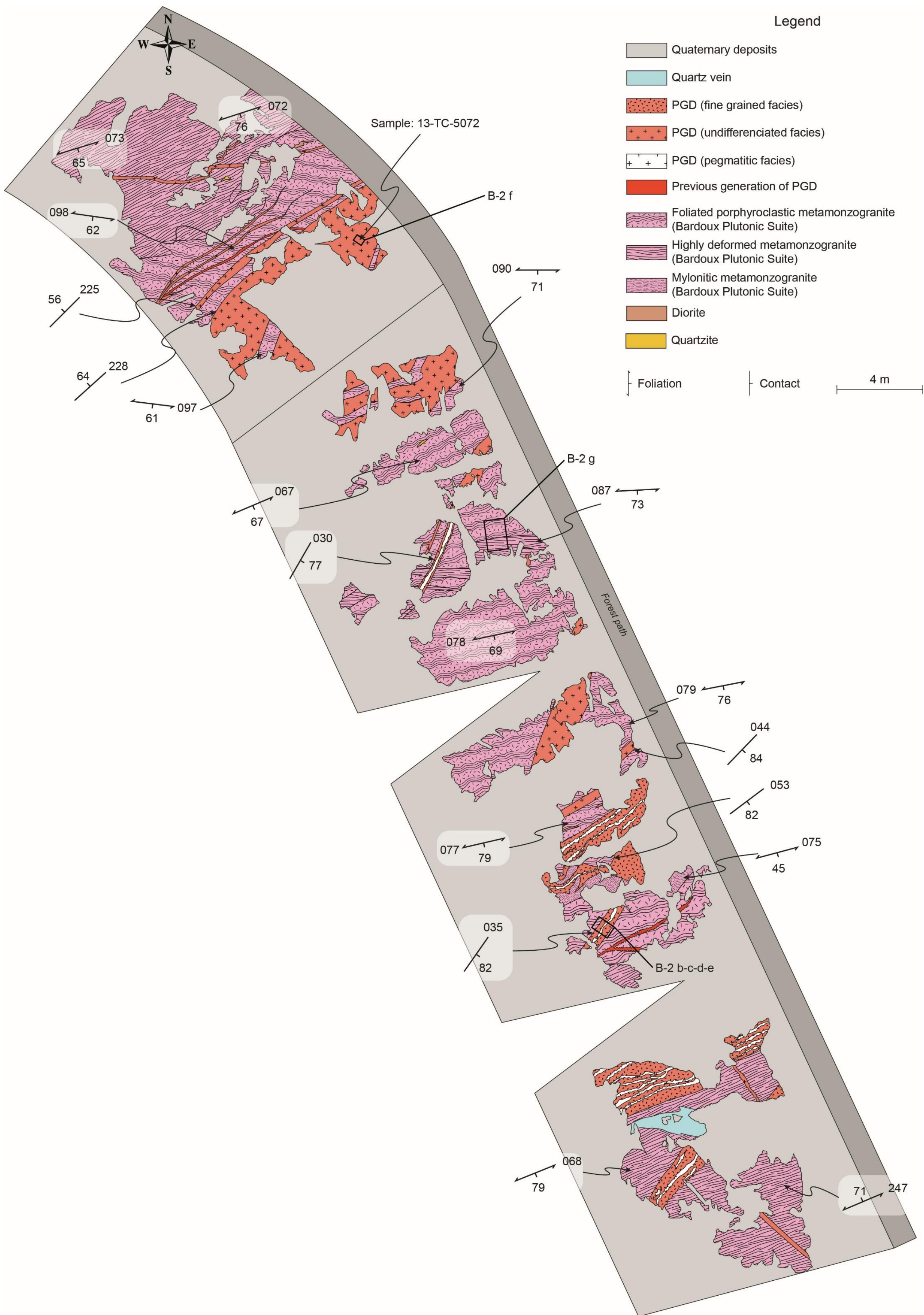


The dykes are steep-dipping and mostly discordant to the fabric of the host metamonzogranite but are locally sub-concordant (Figs. B-2b-c and e, 5b). Several of these dykes may present internal zoning which typically consists in (i) a thin contact (few millimeter to a centimeter wide, zone 1, Figs. B-2b-c), followed by (ii) a ca. 20 to $30 \mathrm{~cm}$ wide fine grained facies (ca. $<1 \mathrm{~mm}$ and $2 \mathrm{~mm}$, zone 2, Figs. B-2b-c), and (iii) by a coarser grain size zone (ca. 1 to $5 \mathrm{~mm}$, zone 3, Figs. B-2b and d). The (iv) core of the dykes (zone 4, Figs. B-2b and d) may vary from a few centimeters to tens of centimeters wide and displays a pegmatitic texture. It is followed by (v) another fine grained facies (zone 5, Figs. B-2b, B-2d-e), which transition is quite diffuse from the later one, that ends at the boundary of the dyke by (vi) the growth of K-feldspar phenocrysts perpendicular to the contact (zone 6, Figs. B-2b and e). The whole contact is not marked by these phenocrysts that also developed in the fine grained facies with no relations with the dyke boundary (Fig. B2e), suggesting that it does not correspond to Stockscheider textures. This kind of internal zoning in the dykes of this outcrop is quite representative as most of them display either this sequence or its repetition, probably related to several magmatic pulses. A few intrusive bodies, mostly wider than the dykes, do not display any evident zoning. Allanite grains (Fig. B-2f) are present in both zoned and unzoned intrusive bodies, and seems mostly associated with fine to medium grained facies.

The intruded metamonzogranite from the Bardoux Plutonic Suite displays various textures related to the degree of deformation it underwent, from a foliated facies with rounded rapakivi K-feldspar porphyroclasts to a mylonitic texture with elongated K-feldspar porphyroclasts (Fig. B-2g). 
Turlin et al. - Unusual LREE-rich, post-tectonic, monazite-or allanite-bearing pegmatitic granites in the central Grenville Province, Québec
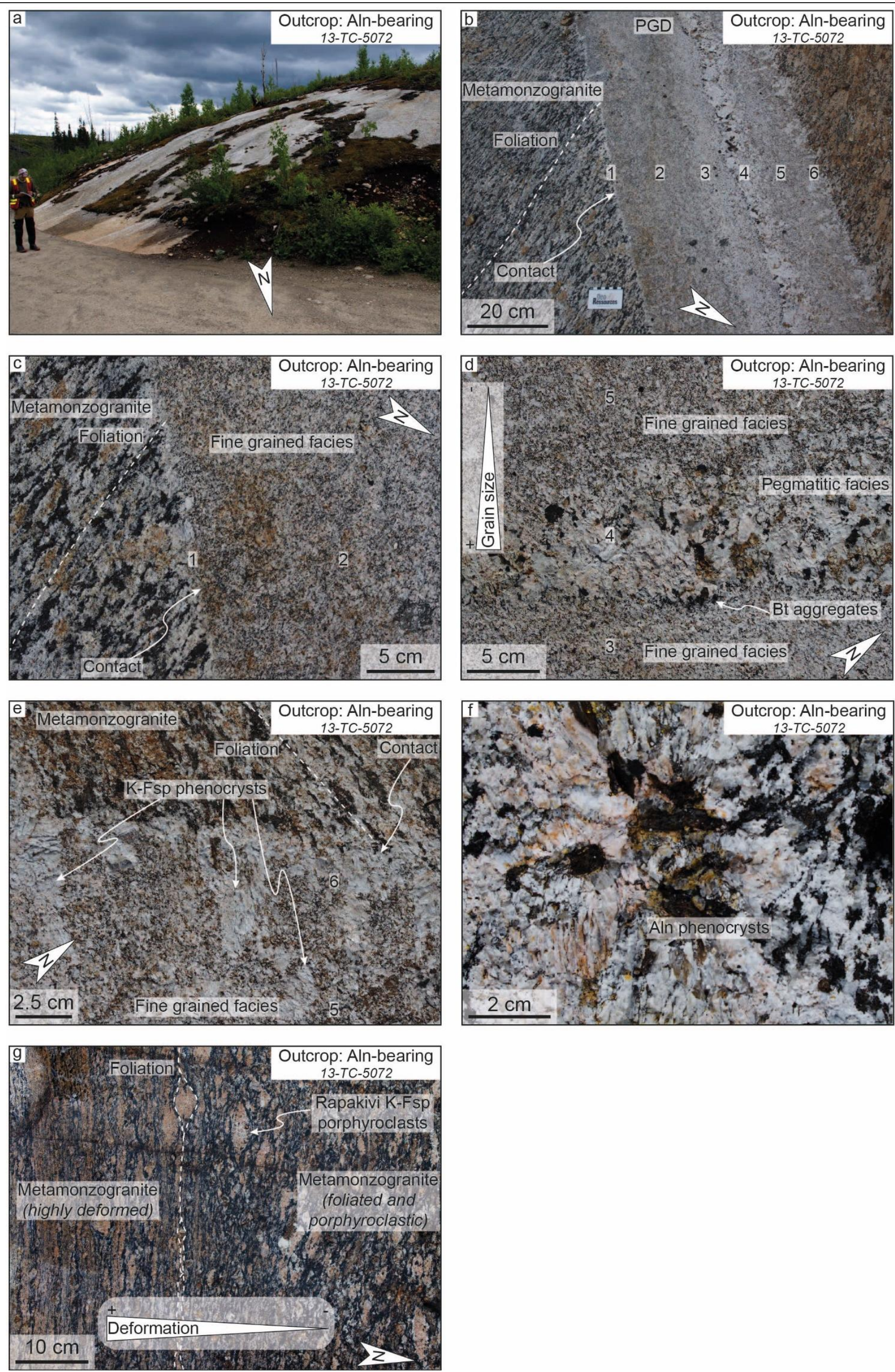
Figure B-2: Photographs of the 13-TC-5072 outcrop from the Lac Okaopéo region. a: general view of the 13-TC-5072 outcrop composed of a pegmatitic granite intruding as a dyke swarm a metamonzogranite from the Bardoux Plutonic Suite; b: typical dyke zonation of the 13-TC-5072 pegmatitic dykes, with a southeastern boundary (1) marked by a thin zone of reaction with the host rock developed over a few millimeters with almost no biotite, followed by a fine grained facies with increasing grain size and proportions of biotite $(2,3)$ up to a pegmatitic core (4). This core is followed by a progressive fine grained facies with decreasing grain size zone (5). The northern contact (6) is marked by the development of K-feldspar phenocrysts perpendicular to the contact. Note that the dyke is discordant to the foliation of the intruded metamonzogranite; c: detailed view of the southern contact presented in figure $b$. Numbers refer to the zones identified in figure b; $d$ : detailed view of the pegmatitic core of the dyke presented in figure $b$. Note the pegmatitic facies is underlined on its southern boundary by biotite aggregates whereas the northern one is opened to a fine grained facies which transition is undulating along the core. Numbers refer to the zones identified in figure b; e: detailed view of the northern contact presented in figure b. Note the diffuse boundary and the crystallization of K-feldspar phenocrysts perpendicular to the contact. Numbers refer to the zones identified in figure b; $f$ : typical allanite phenocrysts in pegmatitic granite dykes intruding the metamonzogranite; g: typical metamonzogranite facies variations from a foliated and porphyroclastic facies where porphyroclasts of rapakivi K-feldspar are wrapped by the foliation (north) to transposed in a highly deformed facies (south). Abbreviations: Aln = allanite; Aln-bearing = allanite-bearing pegmatitic granite dyke; $\mathrm{Bt}=$ biotite; $\mathrm{K}-\mathrm{Fsp}=\mathrm{K}$-feldspar; $\mathrm{PGD}=$ pegmatitic granite dyke. 


\section{13-FS-1202 allanite-bearing PGD}

The 13-FS-1202 allanite-bearing PGD and REE occurrence is located at the south of the 13-TC-5072 PGD, in the south of the 22K/10 NTS sheet (Fig. 3), and is exposed as a large (several tens square meters in surface) and flat lying outcrop (Fig. B-4a). The detailed map of this outcrop is available in the Fig. B-3. It consists in numerous straight pinkish (fresh color) PGD (2-5 m wide, Figs. B-3 and B-4b) intruding a quartz metamonzodiorite from the Castoréum Plutonic Suite. 


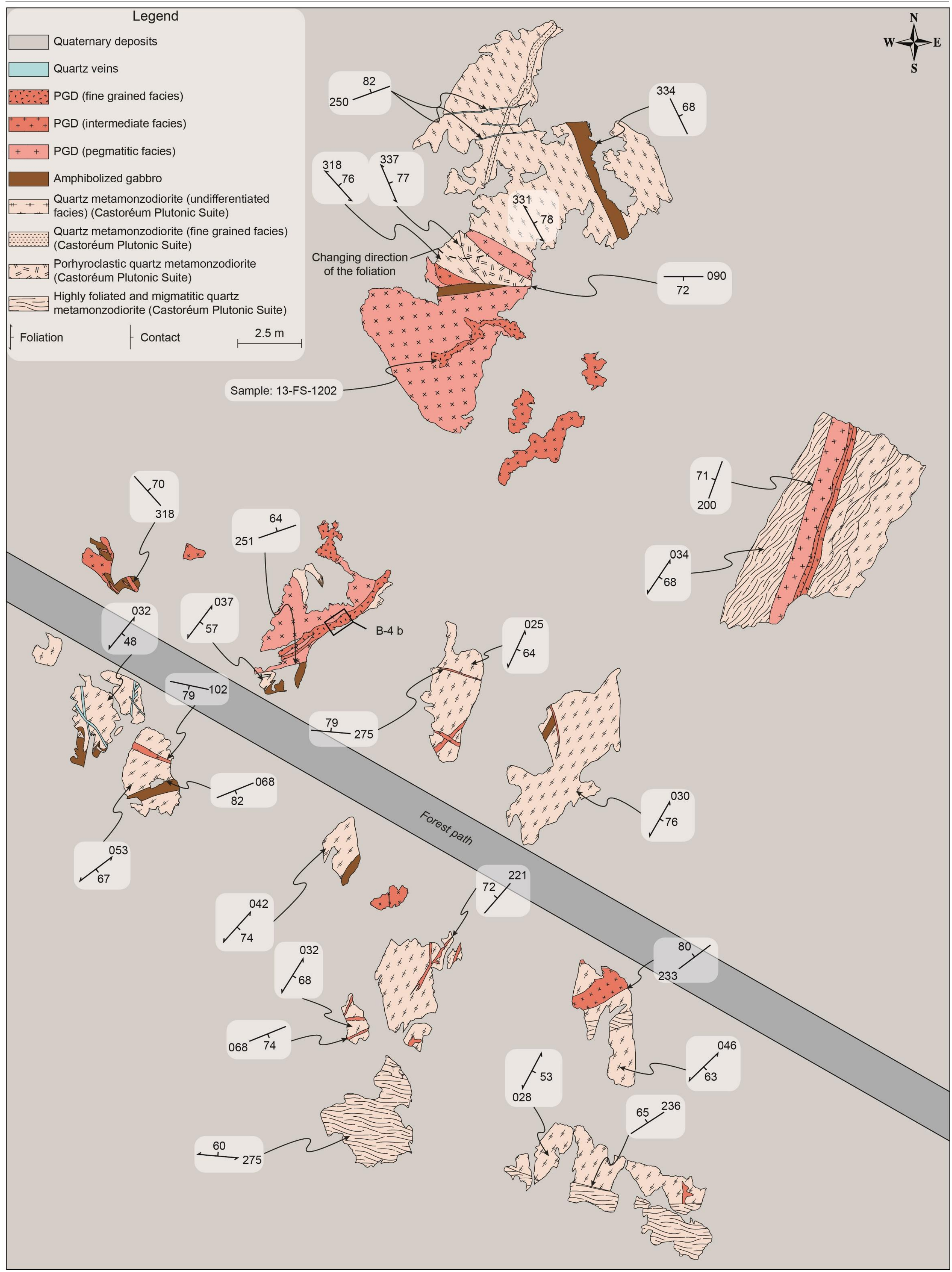




\section{ACCEPTED MANUSCRIPT}

Turlin et al. - Unusual LREE-rich, post-tectonic, monazite- or allanite-bearing pegmatitic granites

in the central Grenville Province, Québec

The dykes are steep-dipping and slightly to strongly discordant to the fabric of the host

2 quartz metamonzodiorite (Fig. 5b). The contacts of the PGD with their hosts are straight or

3 irregular, and are slightly diffuse (over a few millimeters). This dyke is mainly composed of

4 quartz, feldspar and biotite and contains large allanite phenocrysts (>1 cm, Fig. B-4b). The

5 most mineralized zone, i.e. containing the most allanite grains that may reach over $1 \mathrm{~cm}$,

6 corresponds to an intermediate facies which is layered with a pegmatitic $($ over $3 \mathrm{~cm}$ ) barren

7 facies at the contact and a finer-grained $(0.1-3 \mathrm{~cm})$ allanite-rich facies in the center (Fig. B-

4b). The rest of the PGD does not display any sign of organization with random patches

ranging from a medium grained allanite-rich facies to a coarse grained barren facies. Coarse

grained to pegmatitic facies may locally present allanite aggregates.
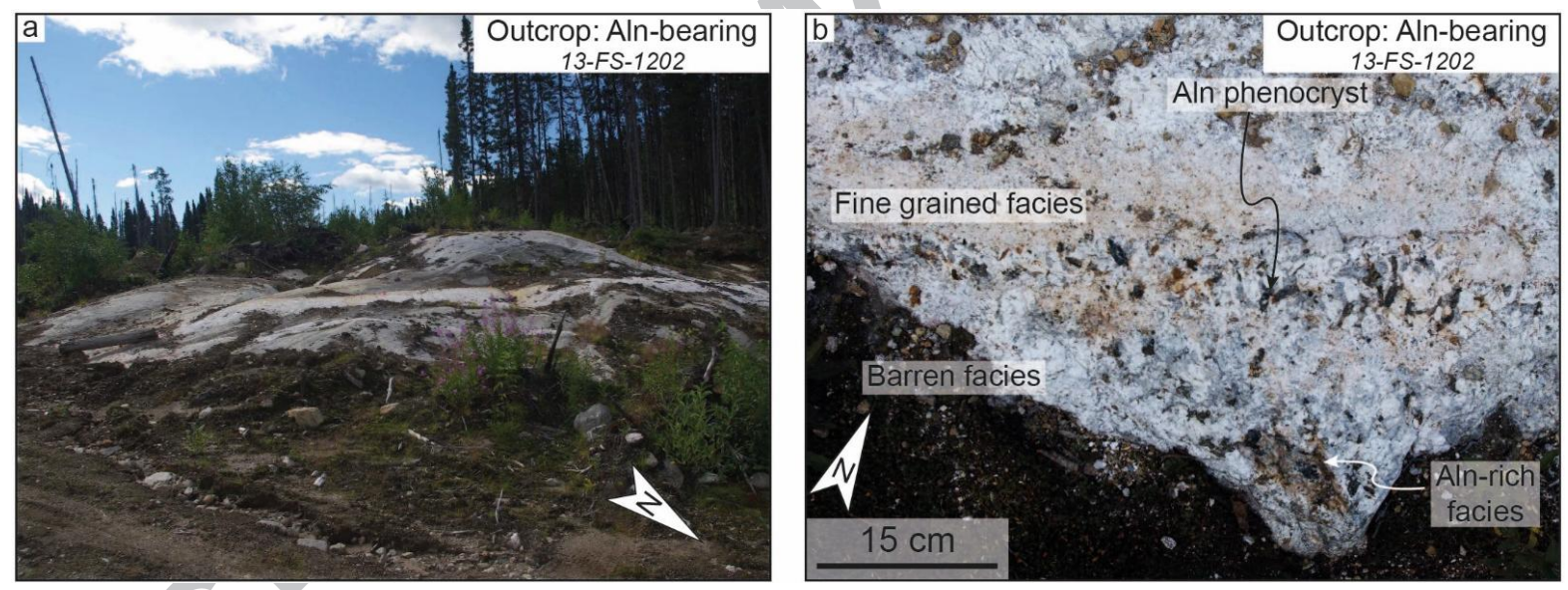

Figure B-4: Photographs of the 13-FS-1202 outcrop from the Lac Okaopéo region. a: general view of the 13-FS1202 outcrop composed of a pegmatitic granite intruding as a dyke swarm a quartz metamonzodiorite from the Castoréum Plutonic Suite; b: detailed view of the typical zoning observed in the pegmatitic granite. Note allanite; Aln-bearing = allanite-bearing pegmatitic granite dyke; $Q z$ = quartz. 


\section{ACCEPTED MANUSCRIPU}

Turlin et al. - Unusual LREE-rich, post-tectonic, monazite- or allanite-bearing pegmatitic
granites
in the central Grenville Province, Québec

\section{13-AE-2149 allanite-bearing PGD}

The 13-AE-2149 allanite-bearing PGD and REE occurrence is located in the north of the 22K/07 NTS sheet (Fig. 3) and is exposed as a large and steep-dipping outcrop. The detailed map of this outcrop is available in the Fig. B-5. It consists in a main straight pinkish PGD (up to ca. $1 \mathrm{~m}$ wide, Figs. B-5 and B-6a) intruding a layered metamangerite from the Castoréum Plutonic Suite.

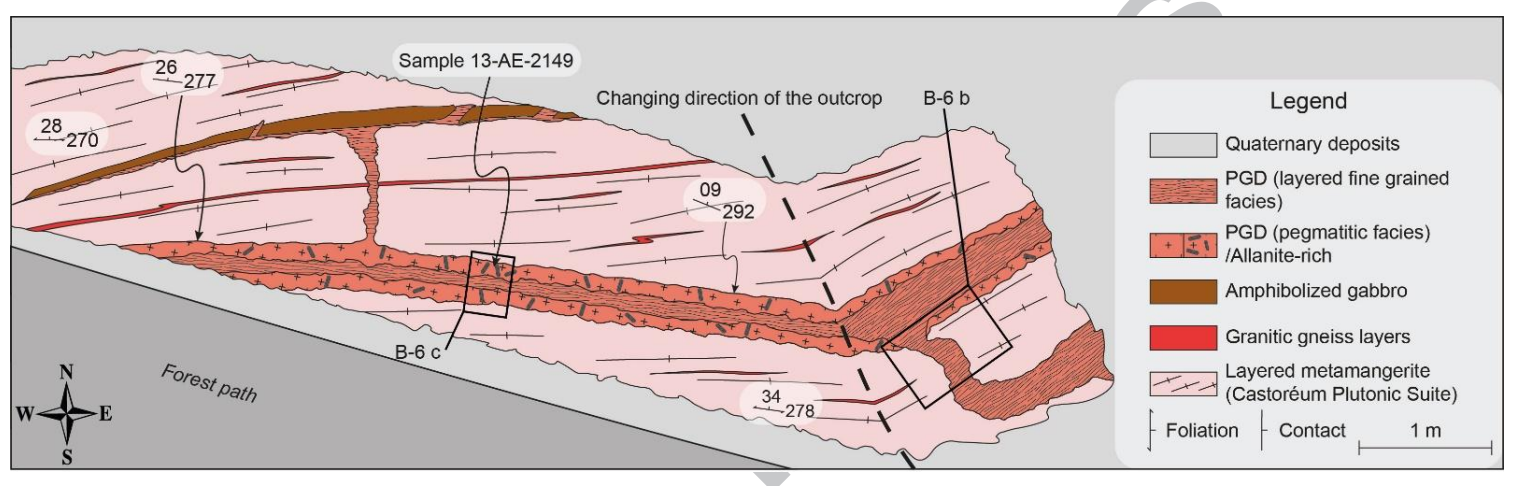

Figure B-5: Detailed map of the 13-AE-2149 outcrop made of a layered metamangerite from the Castoréum Plutonic Suite intruded by a discordant REE-rich pegmatitic granite dyke. Abbreviation: PGD = pegmatitic granite dyke.

This PGD is connected to a network of texturally continuous veins concordant and discordant to the foliation of the host layered metamangerite from the Castoréum Plutonic Suite (Fig. B-6b). The main dyke is shallow-dipping (Fig. 5b) and the contact between the PGD and the metamangerite is slightly discordant to locally sub-concordant and may be very diffuse (Figs. B-6c, 5b).

The upper contact of the dyke is marked by a ca. $20 \mathrm{~cm}$ wide pegmatitic facies with a grain size over $10 \mathrm{~cm}$. A few large allanite phenocrysts are disseminated across this contact, and may reach over $10 \mathrm{~cm}$ (Fig. B-6c). The core of the dyke is composed of a layered fine grained facies composed of alternating (i) quartz-K-feldspar-rich lenses, and (ii) quartzplagioclase-rich lenses that are generally not longer than $30 \mathrm{~cm}$ (Fig. B-6c). The lower contact of the dyke is similarly marked by a pegmatitic facies up to ca. $45 \mathrm{~cm}$ in width (Fig. B-6c). 


\section{ACCEPTED MANUSCRIPT}

Turlin et al. - Unusual LREE-rich, post-tectonic, monazite- or allanite-bearing pegmatitic granites

in the central Grenville Province, Québec

Allanite phenocrysts are up to ca. $10 \mathrm{~cm}$, with a long axis mainly perpendicular to the walls of the dyke. The lower contact of the dyke with the layered metamangerite is more diffuse than at the upper contact and might reflect melt/crystal segregation (Fig. B-6c).

A few meters away from the contacts with granitic veins, the host layered metamangerite displays a homogeneous texture and structure while close to the contacts, the metamangerite grades into a migmatitic gneiss dominated by K-feldspar and clinopyroxene.
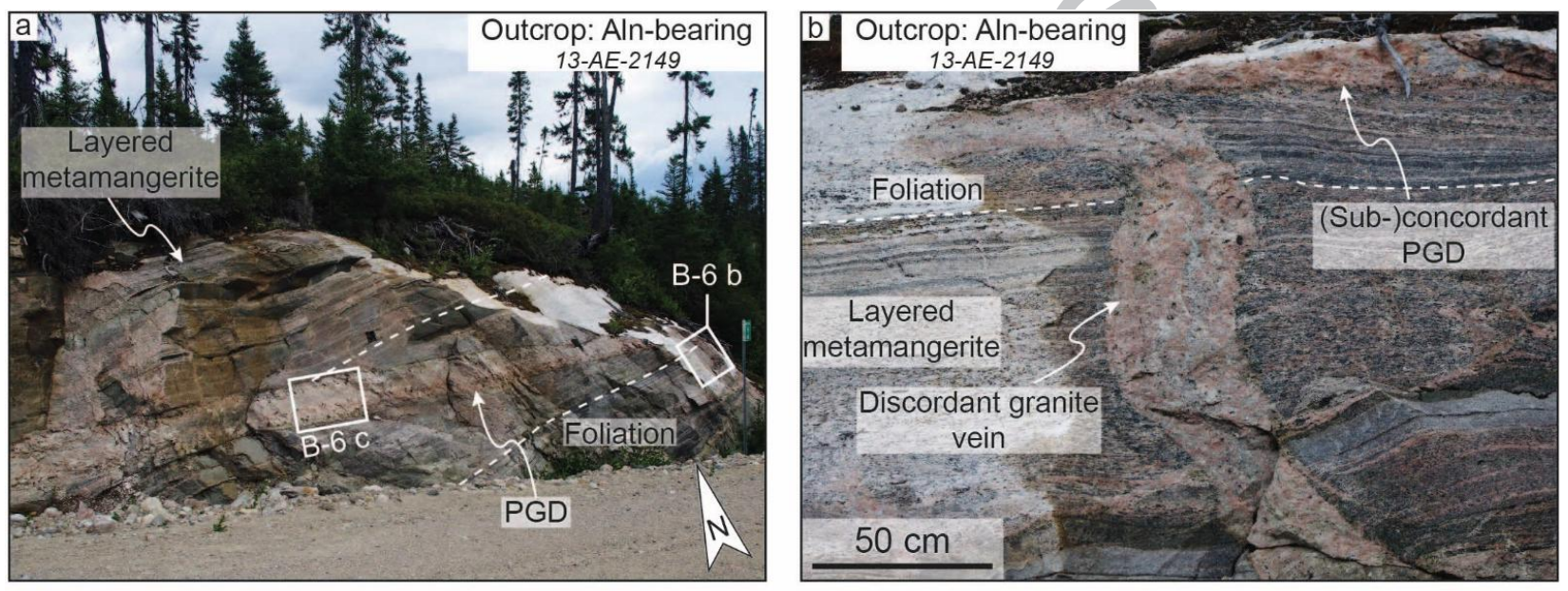

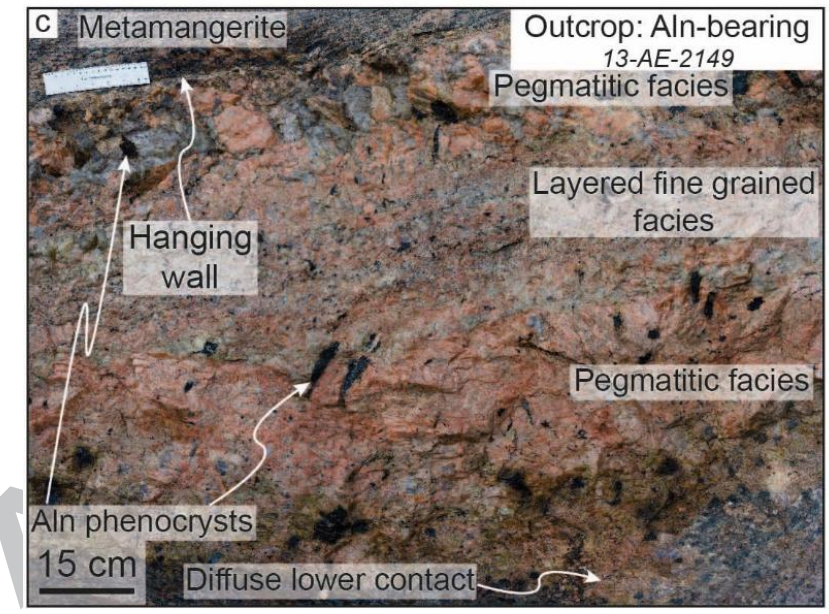

Figure B-6: Photographs of the 13-AE-2149 outcrop from the Lac Okaopéo region. a: general view of the 13AE-2149 outcrop composed of a pegmatitic granite dyke intruding a layered metamangerite from the Castoréum Plutonic Suite; b: detailed view of one of the pegmatitic granite vein discordant to the foliation of its host rock and its connection with the main pegmatitic granite dyke expressed on this outcrop, here with a sub-concordant contact with the layered metamangerite; c: detailed view of the whole dyke zonation from its upper to its lower contact, both marked by a pegmatitic facies with large allanite phenocrysts, through a layered fine grained facies. Abbreviation: Aln = allanite; Aln-bearing = allanite-bearing pegmatitic granite dyke; $P G D=$ pegmatitic granite dyke. 
Turlin et al. - Unusual LREE-rich, post-tectonic, monazite- or allanite-bearing pegmatitic granites

in the central Grenville Province, Québec

\section{References}

Alfonso, P., Melgarejo, J.C., 2008. Fluid Evolution in the Zoned Rare-Element Pegmatite Field at Cap De Creus, Catalonia, Spain. Can. Mineral. 46, 597-617. doi:10.3749/canmin.46.3.597

Augland, L.E., Moukhsil, A., Solgadi, F., Indares, A., McFarlane, C., 2015. Pinwarian to Grenvillian magmatic evolution in the central Grenville Province: new constraints from ID-TIMS U-Pb ages and coupled Lu-Hf S-MC-ICP-MS data. Can. J. Earth Sci. 52, 701-721. doi:10.1139/cjes-2014-0232

Ayres, L.D., Černý, P., 1982. Metallogeny of granitoid rocks in the Canadian Shield. Can. Mineral. 20, 439-536.

Ballouard, C., Boulvais, P., Poujol, M., Gapais, D., Yamato, P., Tartèse, R., Cuney, M., 2015. Tectonic record, magmatic history and hydrothermal alteration in the Hercynian Guérande leucogranite, Armorican Massif, France. Lithos 220-223, 1-22. doi:10.1016/j.lithos.2015.01.027

Bea, F., 1996. Residence of REE, Y, Th and U in Granites and Crustal Protoliths; Implications for the Chemistry of Crustal Melts. J. Petrol. 37, 521-552. doi:10.1093/petrology/37.3.521

Berger, A., Rosenberg, C., Schaltegger, U., 2009. Stability and isotopic dating of monazite and allanite in partially molten rocks: examples from the Central Alps. Swiss J. Geosci. 102, 15-29. doi:10.1007/s00015-009-1310-8

Bergeron, A., 1980. Petrographie et geochimie du complexe igne alcalin de crevier et de son encaissant metasomatise (Unpublished MSc thesis). Université du Québec à Chicoutimi, Chicoutimi. 
Turlin et al. - Unusual LREE-rich, post-tectonic, monazite- or allanite-bearing pegmatitic granites

in the central Grenville Province, Québec

Budzyń, B., Harlov, D.E., Williams, M.L., Jercinovic, M.J., 2011. Experimental determination of stability relations between monazite, fluorapatite, allanite, and REEepidote as a function of pressure, temperature, and fluid composition. Am. Mineral. 96, 1547-1567. doi:10.2138/am.2011.3741

Carr, S.D., Easton, R.M., Jamieson, R.A., Culshaw, N.G., 2000. Geologic transect across the Grenville orogen of Ontario and New York. Can. J. Earth Sci. 37, 193-216. doi:10.1139/e99-074

Černý, P., 1991. Rare-element Granitic Pegmatites. Part I: Anatomy and Internal Evolution of Pegmatitic Deposits. Geosci. Can. 18, 49-67.

Černý, P., 1990. Distribution, affiliation and derivation of rare-element granitic pegmatites in the Canadian Shield. Geol. Rundsch. 79, 183-226. doi:10.1007/BF01830621

Černý, P., Ercit, T.S., 2005. The classification of granitic pegmatites revisited. Can. Mineral. 43, Part 6, 2005-2026.

Černý, P., London, D., Novák, M., 2012. Granitic Pegmatites as Reflections of Their Sources. Elements 8, 289-294. doi:10.2113/gselements.8.4.289

Chappell, B.W., White, A.J.R., 2001. Two contrasting granite types: 25 years later. Aust. J. Earth Sci. 48.

Crowley, J.L., Brown, R.L., Gervais, F., Gibson, H.D., 2008. Assessing Inheritance of Zircon and Monazite in Granitic Rocks from the Monashee Complex, Canadian Cordillera. J. Petrol. 49, 1915-1929. doi:10.1093/petrology/egn047

Cuney, M., 2014. Felsic magmatism and uranium deposits. B. Soc. Geol. Fr. 185, 75-92. doi:10.2113/gssgfbull.185.2.75 
Turlin et al. - Unusual LREE-rich, post-tectonic, monazite- or allanite-bearing pegmatitic granites

in the central Grenville Province, Québec

David, J., 2006. Géochronologie d'échantillons provenant de Géologie Québec, année 20052006 - Rapport final. Ministère de l'Energie et des Ressources Naturelles, Québec GM 63236, $12 \mathrm{p}$.

David, J., Moukhsil, A., Clark, T., Hébert, C., Nantel, S., Dion, C., Sappin, A.-A., 2009. Datations U-Pb effectuées dans les provinces de Grenville et de Churchill en 20062007. Ministère des Ressources naturelles et de la Faune, Québec, RP2009-03, 32 p.

Dill, H.G., 2016. The CMS classification scheme (Chemical composition-Mineral assemblage-Structural geology) - linking geology to mineralogy of pegmatitic and aplitic rocks. N. Jb. Miner. Abh. (J. Min. Geochem.) 193, 231-263.

Dill, H.G., 2015. Pegmatites and aplites: Their genetic and applied ore geology. Ore Geol. Rev. 69, 417-561. doi:10.1016/j.oregeorev.2015.02.022

Dill, H.G., 2010. The "chessboard" classification scheme of mineral deposits: Mineralogy and geology from aluminum to zirconium. Earth Sci. Rev. 100, 1-420. doi:10.1016/j.earscirev.2009.10.011

Druguet, E., Castro, A., Chichorro, M., Pereira, M.F., Fernández, C., 2014. Zircon geochronology of intrusive rocks from Cap de Creus, Eastern Pyrenees. Geol. Mag. 151, 1095-1114. doi:10.1017/S0016756814000041

Dunning, G., Indares, A., 2010. New insights on the 1.7-1.0 Ga crustal evolution of the central Grenville Province from the Manicouagan - Baie Comeau transect. Precambrian Res. 180, 204-226. doi:10.1016/j.precamres.2010.04.005

Ellison, A.J., Hess, P.C., 1986. Solution behavior of +4 cations in high silica melts: petrologic and geochemical implications. Contr. Mineral. Petrol. 94, 343-351. doi:10.1007/BF00371443 
Turlin et al. - Unusual LREE-rich, post-tectonic, monazite- or allanite-bearing pegmatitic granites

in the central Grenville Province, Québec

122

126

Ercit, T.S., 2005. REE-enriched granitic pegmatites. Short Course Notes - Geological Association of Canada 17, 175-199.

Ford, K.L., 1982. Uraniferous pegmatites of the Sharbot Lake area, Ontario, Uranium in Granites. Geological Survey Canada, Paper 81-23.

Fowler, A.D., Doig, R., 1983. The significance of europium anomalies in the REE spectra of granites and pegmatites, Mont Laurier, Quebec. Geochim. Cosmochim. Ac. 47, 11311137. doi:10.1016/0016-7037(83)90243-0

Frost, B.R., Barnes, C.G., Collins, W.J., Arculus, R.J., Ellis, D.J., Frost, C.D., 2001. A geochemical classification for granitic rocks. J. Petrol. 42, 2033-2048.

Gasquet, D., Bertrand, J.-M., Paquette, J.-L., Lehmann, J., Ratzov, G., Guedes, R.D.A., Tiepolo, M., Boullier, A.-M., Scaillet, S., Nomade, S., 2010. Miocene to Messinian deformation and hydrothermal activity in a pre-Alpine basement massif of the French western Alps: new U-Th-Pb and argon ages from the Lauzière massif. B. Soc. Geol. Fr. 181, 227-241. doi:10.2113/gssgfbull.181.3.227

Gauthier, M., Chartrand, F., 2005. Metallogeny of the Grenville Province revisited. Can. J. Earth Sci. 42, 1719-1734. doi:10.1139/E05-051

Gauthier, M., Chartrand, F., Cayer, A., David, J., 2004. The Kwyjibo Cu-REE-U-Au-Mo-F Property, Quebec: A Mesoproterozoic Polymetallic Iron Oxide Deposit in the Northeastern Grenville Province. Econ. Geol. 99, 1177-1196. doi:10.2113/gsecongeo.99.6.1177

Gervais, F., Crowley, J.L., 2017. Prograde and near-peak zircon growth in a migmatitic pelitic schist of the southeastern Canadian Cordillera. Lithos 282-283, 65-81. doi:10.1016/j.lithos.2017.02.016 
Turlin et al. - Unusual LREE-rich, post-tectonic, monazite- or allanite-bearing pegmatitic granites

in the central Grenville Province, Québec

145

146

147

148

150

151

152

153

154

155

156

157

158

160

161

162

163

164

165

166

167

Gobeil, A., Hébert, C., Clark, T., Beaumier, M., Perreault, S., 2002. Géologie de la région du lac De la Blache (22K/03 et 22K/04). Ministère des Ressources Naturelles, Québec, RG 2002-01, 53 p.

Goodenough, K.M., Schilling, J., Jonsson, E., Kalvig, P., Charles, N., Tuduri, J., Deady, E.A., Sadeghi, M., Schiellerup, H., Müller, A., Bertrand, G., Arvanitidis, N., Eliopoulos, D.G., Shaw, R.A., Thrane, K., Keulen, N., 2016. Europe's rare earth element resource potential: An overview of REE metallogenetic provinces and their geodynamic setting. Ore Geol. Rev. 72, Part 1, 838-856. doi:10.1016/j.oregeorev.2015.09.019

Gower, C.F., Krogh, T.E., 2002. A U-Pb geochronological review of the Proterozoic history of the eastern Grenville Province. Can. J. Earth Sci. 39, 795-829. doi: 10.1139/E01090

Groulier, P.-A., 2013. Étude des minéralisations en Nb-Ta du complexe igné alcalin de Crevier (Québec) (Rapport de Master), Université de Lorraine, 77 p.

Hanchar, J.M., Finch, R.J., Hoskin, P.W.O., Watson, E.B., Cherniak, D.J., Mariano, A.N., 2001. Rare earth elements in synthetic zircon: Part 1. Synthesis, and rare earth element and phosphorus doping. Am. Mineral. 86, 667-680. doi:10.2138/am-2001-5-607

Hoffman, P.F., 1989. Precambrian geology and tectonic history of North America The geology of North America. Geol. Soc. Am. : Boulder, CO, United States, United States, pp. 447-512.

Hönig, S., Čopjaková, R., Škoda, R., Novák, M., Dolejš, D., Leichmann, J., Galiová, M.V., 2014. Garnet as a major carrier of the $\mathrm{Y}$ and REE in the granitic rocks: An example from the layered anorogenic granite in the Brno Batholith, Czech Republic. Am. Mineral. 99, 1922-1941. doi:10.2138/am-2014-4728 
Turlin et al. - Unusual LREE-rich, post-tectonic, monazite- or allanite-bearing pegmatitic granites in the central Grenville Province, Québec

Hulsbosch, N., Hertogen, J., Dewaele, S., André, L., Muchez, P., 2014. Alkali metal and rare earth element evolution of rock-forming minerals from the Gatumba area pegmatites (Rwanda): Quantitative assessment of crystal-melt fractionation in the regional zonation of pegmatite groups. Geochim. Cosmochim. Ac. 132, 349-374. doi:10.1016/j.gca.2014.02.006

Hynes, A., Indares, A., Rivers, T., Gobeil, A., 2000. Lithoprobe line 55: integration of out-ofplane seismic results with surface structure, metamorphism, and geochronology, and the tectonic evolution of the eastern Grenville Province. Can. J. Earth Sci. 37, 341358. doi:10.1139/e99-076

Indares, A., Dunning, G., 2004. Crustal architecture above the high-pressure belt of the Grenville Province in the Manicouagan area: new structural, petrologic and $\mathrm{U}-\mathrm{Pb}$ age constraints. Precambrian Res. 130, 199-228. doi:10.1016/j.precamres.2003.11.005

Indares, A., Dunning, G., 2001. Partial Melting of High-P-T Metapelites from the Tshenukutish Terrane (Grenville Province): Petrography and U-Pb Geochronology. J. Petrol. 42, 1547-1565. doi:10.1093/petrology/42.8.1547

Indares, A., Dunning, G., Cox, R., 2000. Tectono-thermal evolution of deep crust in a Mesoproterozoic continental collision setting: the Manicouagan example. Can. J. Earth Sci. 37, 325-340. doi:10.1139/e99-069

Indares, A., Dunning, G., Cox, R., Gale, D., Connelly, J., 1998. High-pressure, hightemperature rocks from the base of thick continental crust: Geology and age constraints from the Manicouagan Imbricate Zone, eastern Grenville Province. Tectonics 17, 426-440. doi:10.1029/98TC00373 
Turlin et al. - Unusual LREE-rich, post-tectonic, monazite- or allanite-bearing pegmatitic granites

in the central Grenville Province, Québec

190

191

192

194

195

196

198

199

201

202

203

204

205

206

207

208

209

210

Jannin, S., Gervais, F., Moukhsil, A., Crowley, J.L., Augland, L.E., In press. Datation U/Pb des déformations inverses et normales dans la Province de Grenville central (Manicouagan, Québec): évidence d'un chenal orogénique dans le Parautochtone, in: Géologie et Ressources Minérales de La Partie Centrale de La Province de Grenville; Abdelali Moukhsil Coordonnateur, Ministère de l'Énergie et Des Ressources Naturelles, Québec.

Jordan, S.L., Indares, A., Dunning, G., 2006. Partial melting of metapelites in the Gagnon terrane below the high-pressure belt in the Manicouagan area (Grenville Province): pressure-temperature $(\mathrm{P}-\mathrm{T})$ and $\mathrm{U}-\mathrm{Pb}$ age constraints and implications. Can. J. Earth Sci. 43, 1309-1329. doi:10.1139/E06-038

Ketchum, J.W.F., Heaman, L.M., Krogh, T.E., Culshaw, N.G., Jamieson, R.A., 1998. Timing and thermal influence of late orogenic extension in the lower crust: a U-Pb geochronological study from the southwest Grenville orogen, Canada. Precambrian Res. 89, 25-45. doi:10.1016/S0301-9268(97)00079-X

Ketchum, J.W.F., Jamieson, R.A., Heaman, L.M., Culshaw, N.G., Krogh, T.E., 1994. 1.45 Ga granulites in the southwestern Grenville province: Geologic setting, P-T conditions, and U-Pb geochronology. Geology 22, 215-218. doi:10.1130/00917613(1994)022<0215:GGITSG $>2.3 . C O ; 2$

Krogh, T.E., 1994. Precise U-Pb ages for Grenvillian and pre-Grenvillian thrusting of Proterozoic and Archean metamorphic assemblages in the Grenville Front tectonic zone, Canada. Tectonics 13, 963-982. doi:10.1029/94TC00801

Lasalle, S., Dunning, G., Indares, A., 2014. In situ LA-ICP-MS dating of monazite from aluminous gneisses: insights on the tectono-metamorphic history of a granulite-facies 
Turlin et al. - Unusual LREE-rich, post-tectonic, monazite- or allanite-bearing pegmatitic granites

in the central Grenville Province, Québec

domain in the central Grenville Province. Can. J. Earth Sci. 51, 558-572. doi:10.1139/cjes-2013-0170

Lasalle, S., Fisher, C.M., Indares, A., Dunning, G., 2013. Contrasting types of Grenvillian granulite facies aluminous gneisses: Insights on protoliths and metamorphic events from zircon morphologies and ages. Precambrian Res. 228, 117-130. doi:10.1016/j.precamres.2013.01.014

Lasalle, S., Indares, A., 2014. Anatectic record and contrasting P-T paths of aluminous gneisses from the central Grenville Province. J. Metamorph. Geol. 32, 627-646. doi:10.1111/jmg.12083

Lentz, D., 1996. U, Mo, and REE mineralization in late-tectonic granitic pegmatites, southwestern Grenville Province, Canada. Ore Geol. Rev. 11, 197-227. doi:10.1016/0169-1368(95)00034-8

Lentz, D.R., 1991. Petrogenesis of uranium-, thorium-, molybdenum-, and rare earth elementbearing pegmatites, skarns, and veins in the central metasedimentary belt of the Grenville Province, Ontario and Quebec. (Unpublished Ph.D. thesis). University of Ottawa (Canada), $491 \mathrm{p}$.

Linnen, R.L., 1998. The solubility of Nb-Ta-Zr-Hf-W in granitic melts with $\mathrm{Li}$ and $\mathrm{Li}+\mathrm{F}$; constraints for mineralization in rare metal granites and pegmatites. Econ. Geol. 93, 1013-1025. doi:10.2113/gsecongeo.93.7.1013

Linnen, R.L., Cuney, M., 2005. Granite-related rare-element deposits and experimental constraints on Ta-Nb-W-Sn-Zr-Hf mineralization. Short Course Notes - Geological Association of Canada 17, 45-68. 
Turlin et al. - Unusual LREE-rich, post-tectonic, monazite- or allanite-bearing pegmatitic granites

in the central Grenville Province, Québec

Linnen, R.L., Keppler, H., 2002. Melt composition control of $\mathrm{Zr} / \mathrm{Hf}$ fractionation in magmatic processes. Geochim. Cosmochim. Ac. 66, 3293-3301. doi:10.1016/S00167037(02)00924-9

London, D., 2016. Rare-Element Granitic Pegmatites. Rev. Econ. Geol. 18, 165-193.

London, D., 2008. Pegmatites, Can. Mineral. Spec. Publ. 10, 368 p.

London, D., 2005. Granitic pegmatites: an assessment of current concepts and directions for the future. Lithos 80, 281-303. doi:10.1016/j.lithos.2004.02.009

Ludwig, K.R., 2001. Isoplot/Ex Version 2.49. A Geochronological Toolkit for Microsoft Excel. Berkeley Geochronology Center, Special Publication vol. 1a, pp. 1-55.

Ludwig, K.R., 1998. On the Treatment of Concordant Uranium-Lead Ages. Geochim. Cosmochim. Ac. 62, 665-676. doi:10.1016/S0016-7037(98)00059-3

Lumbers, S.B., 1979. The Grenville Province of Ontario, in: 5th Ann. Meeting Int. Union Geol. Sci, Subcomm. Precamb. Stratigraphy. pp. 1-35.

Lumbers, S.B., 1964. Preliminary report on the relationship of mineral deposits to intrusive rocks and metamorphism in part of the Grenville Province of southeastern Ontario. Ont. Dep. Mines Rep. No. PR1964-4.

Martin, R.F., De Vito, C., 2005. The Patterns of Enrichment in Felsic Pegmatites Ultimately Depend on Tectonic Setting. Can. Mineral. 43, 2027-2048. doi:10.2113/gscanmin.43.6.2027

Masson, S.L., Gordon, J.B., 1981. Radioactive mineral deposits of the Pembroke-Renfrew area. Ont. Geol. Surv. Mineral Deposits Circ., No. 23. 
Turlin et al. - Unusual LREE-rich, post-tectonic, monazite- or allanite-bearing pegmatitic granites

in the central Grenville Province, Québec

McDonough, W.F., Sun, S. -s., 1995. The composition of the Earth. Chem. Geol. 120, 223253. doi:10.1016/0009-2541(94)00140-4

Melcher, F., Graupner, T., Gäbler, H.-E., Sitnikova, M., Henjes-Kunst, F., Oberthür, T., Gerdes, A., Dewaele, S., 2015. Tantalum-(niobium-tin) mineralisation in African pegmatites and rare metal granites: Constraints from $\mathrm{Ta}-\mathrm{Nb}$ oxide mineralogy, geochemistry and U-Pb geochronology. Ore Geol. Rev. 64, 667-719. doi:10.1016/j.oregeorev.2013.09.003

Montel, J.-M., 1993. A model for monazite/melt equilibrium and application to the generation of granitic magmas. Chem. Geol. 110, 127-146. doi:10.1016/0009-2541(93)90250-M

Moukhsil, A., Lacoste, P., Gobeil, A., David, J., 2009. Synthèse géologique de la région de Baie-Comeau. Ministère des Ressources naturelles et de la Faune, Québec, RG 2009$03,30 \mathrm{p}$.

Moukhsil, A., Lacoste, P., Simard, M., Perreault, S., 2007. Géologie de la région septentrionale de Baie-Comeau (22F07, 22F08, 22F09, 22F15 et 22F16). Ministère des Ressources naturelles et de la Faune, Québec, RP 2007-04, 16 p.

Moukhsil, A., Solgadi, F., Belkacim, S., Elbasbas, A., Augland, L.E., 2014. Géologie de la région du lac Okaopéo, Côte-Nord. Ministère de 1'Energie et des Ressources Naturelles, Québec, RG 2014-03, 34 p.

Moukhsil, A., Solgadi, F., Clark, T., Blouin, S., Indares, A., Davis, D.W., 2013a. Géologie du nord-ouest de la région du barrage Daniel-Johnson (Manic 5), Côte-Nord. Ministère des Ressources Naturelles, Québec, RG 2013-01, 46 p. 
Turlin et al. - Unusual LREE-rich, post-tectonic, monazite- or allanite-bearing pegmatitic granites

in the central Grenville Province, Québec

Moukhsil, A., Solgadi, F., Indares, A., Belkacim, S., 2013b. Géologie de la région septentrionale du réservoir aux Outardes 4, Côte-Nord. Ministère des Ressources Naturelles, Québec, RG 2013-03, 33 p.

Moukhsil, A., Solgadi, F., Lacoste, P., Gagnon, M., David, J., 2012. Géologie de la région du lac du Milieu (SNRC 22O03, 22O04, 22O06, 22J13 et 22J14). Ministère des Ressources Naturelles et de la Faune, Québec, RG 2012-01, 33 p.

Paquette, J.L., Tiepolo, M., 2007. High resolution $(5 \mu \mathrm{m}) \mathrm{U}-\mathrm{Th}-\mathrm{Pb}$ isotope dating of monazite with excimer laser ablation (ELA)-ICPMS. Chem. Geol. 240, 222-237. doi:10.1016/j.chemgeo.2007.02.014

Perreault, S., Lafrance, B., 2015. Kwyjibo, a REE-enriched iron oxides-copper-gold (IOCG) deposit, Grenville Province, Québec. Symposium on critical and strategic materials. British Columbia Geological Survey Paper 3, 139-145.

Petrík, I., Broska, I., Lipka, J., Siman, P., 1995. Granitoid Allanite-(Ce) Substitution Relations, Redox Conditions and REE Distributions (on an Example of I-Type Granitoids, Western Carpathians, Slovakia). Geol. Carpath. 46, 79-94.

Rapp, R.P., Watson, E.B., 1986. Monazite solubility and dissolution kinetics: implications for the thorium and light rare earth chemistry of felsic magmas. Contr. Mineral. Petrol. 94, 304-316. doi:10.1007/BF00371439

Rivers, T., 2012. Upper-crustal orogenic lid and mid-crustal core complexes: signature of a collapsed orogenic plateau in the hinterland of the Grenville Province. Can. J. Earth Sci. 49, 1-42. doi:10.1139/e11-014 
Turlin et al. - Unusual LREE-rich, post-tectonic, monazite- or allanite-bearing pegmatitic granites

in the central Grenville Province, Québec

Rivers, T., 2009. The Grenville Province as a large hot long-duration collisional orogen insights from the spatial and thermal evolution of its orogenic fronts. Geol. Soc., Lond., Spec. Publ. 327, 405-444. doi:10.1144/SP327.17

Rivers, T., 2008. Assembly and preservation of lower, mid, and upper orogenic crust in the Grenville Province-Implications for the evolution of large hot long-duration orogens. Precambrian Res. 167, 237-259. doi:10.1016/j.precamres.2008.08.005

Rivers, T., 1997. Lithotectonic elements of the Grenville Province: review and tectonic implications. Precambrian Res. 86, 117-154. doi:10.1016/S0301-9268(97)00038-7

Rivers, T., 1980. Revised stratigraphic nomenclature for Aphebian and other rock units, southern Labrador Trough, Grenville Province. Can. J. Earth Sci. 17, 668-670. doi:10.1139/e80-062

Rivers, T., Culshaw, N., Hynes, A., Indares, A., Jamieson, R., Martignole, J., 2012. The Grenville Orogen - A Post-LITHOPROBE Perspective, in: Tectonic Styles in Canada: The LITHOPROBE Perspective, Geological Association of Canada, Special Paper 49. J.A. Percival, F.A. Cook, and R.M. Clowes, pp. 97-236.

Rivers, T., Ketchum, J., Indares, A., Hynes, A., 2002. The High Pressure belt in the Grenville Province: architecture, timing, and exhumation. Can. J. Earth Sci. 39, 867-893. doi: 10.1139/E02-025.

Rivers, T., Martignole, J., Gower, C.F., Davidson, A., 1989. New tectonic divisions of the Grenville Province, Southeast Canadian Shield. Tectonics 8, 63-84. doi:10.1029/TC008i001p00063 
Turlin et al. - Unusual LREE-rich, post-tectonic, monazite- or allanite-bearing pegmatitic granites

in the central Grenville Province, Québec

Rivers, T., Schwerdtner, W., 2015. Post-peak Evolution of the Muskoka Domain, Western Grenville Province: Ductile Detachment Zone in a Crustal-scale Metamorphic Core Complex. Geosci. Can. 42, 403-436. doi:10.12789/geocanj.2015.42.080

Sangster, A.L., Gauthier, M., Gower, C.F., 1992. Metallogeny of structural zones, Grenville Province, northeastern North America. Precambrian Res. 58, 401-426. doi:10.1016/0301-9268(92)90127-A

Saucier, G., Noreau, C., Casgrain, P., Côté, P., Larochelle, E., Bilodeau, M., Hayden, A., Poirier, E., Garon, M., Bertrand, V., Kissiova, M., Malloux, M., Rouger, M., Camus, Y., Gagnon, G., 2013. NI-43-101 report-feasibility study for the Kipawa project Temiscamingue area, Québec, Canada. Matamec Explorations Inc., Montréal.

Shand, S.J., 1943. The Eruptive Rocks, 2nd edition. ed. New York: John Wiley, 444 p.

Soucy La Roche, R., Gervais, F., Tremblay, A., Crowley, J.L., Ruffet, G., 2015. Tectonometamorphic history of the eastern Taureau shear zone, Mauricie area, Québec: Implications for the exhumation of the mid-crust in the Grenville Province. Precambrian Res. 257, 22-46. doi:10.1016/j.precamres.2014.11.012

Spear, F.S., Pyle, J.M., 2002. Apatite, Monazite, and Xenotime in Metamorphic Rocks. Rev. Mineral. Geochem. 48, 293-335. doi:10.2138/rmg.2002.48.7

Stepanov, A., Mavrogenes, J.A., Meffre, S., Davidson, P., 2014. The key role of mica during igneous concentration of tantalum. Contrib. Mineral. Petrol. 167, 1009-1016. doi:10.1007/s00410-014-1009-3

Tucker, R.D., Gower, C.F., 1994. A U-Pb geochronological framework for the Pinware Terrane, Grenville Province, Southeast Labrador. J. Geol. 102, 67-78. 
Turlin et al. - Unusual LREE-rich, post-tectonic, monazite- or allanite-bearing pegmatitic granites in the central Grenville Province, Québec

Van Achterbergh, E., Ryan, C.G., Jackson, S.E., Griffin, W.L., 2001. Data reduction software for LA-ICP-MS: appendix. Laser-Ablation-ICPMS in the earth sciences-principles and applications. Mineralogical Association of Canada (short course series) 29, $239-$ 243.

van Breemen, O., Currie, K. 1., 2004. Geology and U-Pb geochronology of the Kipawa Syenite Complex — a thrust related alkaline pluton — and adjacent rocks in the Grenville Province of western Quebec. Can. J. Earth Sci. 41, 431-455.

van Gool, J.A.M., Rivers, T., Calon, T., 2008. Grenville Front zone, Gagnon terrane, southwestern Labrador: Configuration of a midcrustal foreland fold-thrust belt. Tectonics 27, TC1004. doi:10.1029/2006TC002095

Van Lichtervelde, M., Grand'Homme, A., Saint-Blanquat, M. de, Olivier, P., Gerdes, A., Paquette, J.-L., Melgarejo, J.C., Druguet, E., Alfonso, P., 2016. U-Pb geochronology on zircon and columbite-group minerals of the Cap de Creus pegmatites, NE Spain. Miner. Petrol., 1-21. doi:10.1007/s00710-016-0455-1

White, A.J.R., Chappell, B.W., 1977. Ultrametamorphism and granitoid genesis. Tectonophysics 43, 7-22. doi:10.1016/0040-1951(77)90003-8

Zaraisky, G.P., Aksyuk, A.M., Devyatova, V.N., Udoratina, O.V., Chevychelov, V.Y., 2009. The $\mathrm{Zr} / \mathrm{Hf}$ ratio as a fractionation indicator of rare-metal granites. Petrol. 17, 25. doi:10.1134/S0869591109010020 
Turlin et al. - Unusual LREE-rich, post-tectonic, monazite- or allanite-bearing pegmatitic granites

in the central Grenville Province, Québec

\section{Figures captions}

362 Figure 1: a: Position of the Grenville orogen in Laurentia. Paleozoic and younger cover 363 omitted (modified from Hoffman, 1989; Rivers, 2008; Rivers et al., 2012). The northern

364 dashed line represents the boundary between Internal and External Paleoproterozoic Laurentia 365 and the southern dashed line represents the Grenville Front (GF). Abbreviations: $1=$ exposed

366 Grenville Province, light grey represents the inferred extension of subsurface allochthonous 367 Grenville Province; 2 = Granite-Rhyolite Igneous Province, ca. 1.50-1.34 Ga and reworked 368 equivalents in the Grenville Province; $3=$ Mid-Continental Rift system; 4 = Paleoproterozoic 369 orogens, ca. 1.9-1.8 Ga, ca. 1.65 Ga and reworked equivalents in the Grenville Province; $5=$ 370 Archean cratons; GF = Grenville Front. b: Simplified tectonic map of the Grenville Province 371 (modified after Rivers, 2008; Rivers et al., 2012). Letters in circle represent the localization of 372 the main Grenvillian granitic pegmatites field as reviewed in Ayres and Černý (1982) and 373 Černý (1990): A = Central Gneiss Belt; B = Central Metasedimentary Belt; $\mathrm{C}=$ Central

374 Granulite Terrain; $\mathrm{D}=$ eastern part of the Grenville Province. Abbreviations: ABT = 375 Allochthon Boundary Thrust; $\mathrm{Cn}=$ Canyon domain; $\mathrm{G}=$ Gagnon Terrane; GF = Grenville 376 Front; HJ = Hart-Jaune terrane; $\mathrm{L}=$ Lelukuau terrane; $\mathrm{Ts}=$ Tshenukutish terrane.

377 Figure 2: Geological map of the central Grenville (Quebec) showing the position of the 378 studied Lac Okaopéo region (NTS sheets 22K/01, 22K/02, 22K/07, 22K/08, 22K/09, 22K/10, modified after Moukhsil et al., 2014). Abbreviations: ABT = Allochthon Boundary Thrust;

380 MIZ = Manicouagan Imbricate Zone.

381 Figure 3: Simplified geological map of the studied Lac Okaopéo region (modified after 382 Moukhsil et al., 2014) showing the geology of the environment of the REE occurrences 383 identified in 2013 by Moukhsil et al. (2014). Stars and diamonds represent monazite-bearing 384 and allanite-bearing pegmatitic granite outcrops respectively. Coordinates of the REE 
Turlin et al. - Unusual LREE-rich, post-tectonic, monazite- or allanite-bearing pegmatitic granites

in the central Grenville Province, Québec

occurrences are proposed in Table $1 .{ }^{1}$ : Augland et al. (2015); ${ }^{2}$ : Gobeil et al. (2002); ${ }^{3}$ : David (2006); ${ }^{4}$ : Dunning and Indares (2010); ${ }^{5}$ : David et al. (2009); ${ }^{6}$ : Moukhsil et al. (2013a); ${ }^{7}$ : Moukhsil et al. (2012); ${ }^{8}$ : Lasalle et al. (2013). Abbreviation: PGD = pegmatitic granite dyke.

Figure 4: Example of detailed map for the 13-AM-13 monazite-bearing pegmatitic granite outcrop from the Lac Okaopéo region showing the relationships between the different identified facies of the pegmatitic granite and the sampling areas. The detailed map for the six other outcrops are proposed in appendices A and B. Abbreviations: $\mathrm{PGD}=$ pegmatitic granite dyke.

Figure 5: Structural measurements of the investigated pegmatitic granite dykes from the Lac Okaopéo region and of the foliation of their host rocks. a: structural measurements from the outcrops of paragneisses-hosted monazite-bearing pegmatitic granite dykes; b: structural measurements from the outcrops of metaplutonic complexes-hosted allanite-bearing pegmatitic granite dykes. Stars and diamonds represent monazite-bearing and allanite-bearing pegmatitic granite outcrops respectively. Note that a larger number of measurements are reported for outcrops of metaplutonic complexes-hosted pegmatitic granite dykes on which allanite-bearing dykes are expressed as dyke swarms. In addition, the concordant/discordant veins connected to the main dyke of the 13-AE-2149 outcrop form a network of undulating veins that do not allow clear 3D observations. Therefore, these veins have not been measured. Abbreviations: Aln-bearing PGD = allanite-bearing pegmatitic granite; Mnz-bearing PGD = monazite-bearing pegmatitic granite.

Figure 6: Representative photographs of the monazite-bearing pegmatitic granite outcrops from the Lac Okaopéo region (from the outcrops 13-AM-07, -13 and 13-TC-5008). a: general view of the 13-AM-13 outcrop composed of a pegmatitic granite intruding paragneisses from the Plus-Value Complex; b: detailed view of Stockscheider-like contact between the 13-AM- 
Turlin et al. - Unusual LREE-rich, post-tectonic, monazite- or allanite-bearing pegmatitic granites

in the central Grenville Province, Québec

07 pegmatitic granite dyke and the intruded paragneisses marked by the crystallization of

410 feldspar from the dyke perpendicular to the contact; c: locally diffuse contact between the 13-

411 TC-5008 pegmatitic granite dyke and the intruded paragneisses delineated by garnet-biotite

412 aggregates; d: typical transition between the fine and coarse grained facies of the 13-AM-13

413 pegmatitic granite dyke underlined by biotite aggregates. Note that the abundance of biotite in

414 the fine grained facies on this photograph is related to the vicinity of the coarse grained facies;

415 e: detailed view of a garnet phenocryst in the fine grained facies; f: monazite crystals from the

416 fine grained facies; g: typical pegmatitic facies essentially composed of a

417 quartz+feldspar+biotite assemblage in which feldspar and biotite crystals can reach over 5

$418 \mathrm{~cm}$; h: arborescent textures made by skeletal crystals reaching up to $15 \mathrm{~cm}$ long in the 13-TC-

4195008 pegmatitic granite dyke. Abbreviations: $\mathrm{Bt}=$ biotite; $\mathrm{Grt}=$ garnet; Fsp = feldspar; $\mathrm{Mnz}$

420 = monazite; Mnz-bearing $=$ monazite-bearing pegmatitic granite PGD $=$ pegmatitic granite

421 dyke; Qz = quartz.

422 Figure 7: Representative photographs of the allanite-bearing pegmatitic granite outcrops from 423 the Lac Okaopéo region (from the outcrops 13-TC-5072, 13-FS-1202 and 13-AE-2149). a: 424 general view of the dome-shaped 13-TC-5072 outcrop composed of a pegmatitic granite 425 intruding as a dyke swarm a metamonzogranite from the Bardoux Plutonic Suite; b: detailed 426 view of the typical zoning observed in the 13-FS-1202 pegmatitic granite. Note that the 427 allanite phenocrysts are associated with a coarse grained facies; c: typical dyke zonation of 428 the 13-TC-5072 pegmatitic dykes, with a southeastern boundary (1) marked by a thin zone of 429 reaction with the host rock developed over a few millimeters with almost no biotite, followed 430 by a fine grained facies with increasing grain size and proportions of biotite $(2,3)$ up to a 431 pegmatitic core (4). This core is followed by a progressive fine grained facies with decreasing 432 grain size zone (5). The northern contact (6) is marked by the development of K-feldspar 433 phenocrysts perpendicular to the contact. Note that these phenocrysts are locally disconnected 
Turlin et al. - Unusual LREE-rich, post-tectonic, monazite- or allanite-bearing pegmatitic granites

in the central Grenville Province, Québec

to the contact that contrast with a Stockscheider-like texture as represented in Fig. 6b, and that dyke is discordant to the foliation of the intruded metamonzogranite; d: typical allanite phenocrysts in pegmatitic granite dykes intruding the metamonzogranite; e: general view of the 13-AE-2149 outcrop composed of a pegmatitic granite dyke intruding a layered metamangerite from the Castoréum Plutonic Suite; f: detailed view of one of the pegmatitic granite vein from the 13-AE-2149 outcrop discordant to the foliation of its host rock and its connection with the main pegmatitic granite dyke expressed on this outcrop, here with a subconcordant contact with the layered metamangerite; g: detailed view of the whole 13-AE2149 shallow-dipping dyke zonation from its hanging wall to its lower contact, both marked by a pegmatitic facies with large allanite crystals, through a layered fine grained facies making the core of the core of the dyke and that also carries disseminated and smaller allanite grains. Abbreviations: Aln = allanite; Aln-bearing = allanite-bearing pegmatitic granite $\mathrm{Bt}=$ biotite; K-Fsp = K-feldspar; PGD = pegmatitic granite dyke.

Figure 8: Typical petrography of monazite-bearing pegmatitic granite dykes from the Lac Okaopéo region. a: major phases composing the monazite-bearing granite (polarized and analysed light); b: syn- to late-zircon growth monazite crystal (SEM); c: late-magmatic crystallization of Th-U \pm REE silicates filling fractures of monazite crystals (SEM); d: latesericite affecting plagioclase (polarized and analysed light). Abbreviations: $\mathrm{Bt}=$ biotite; $\mathrm{Mc}=$ microcline; $\mathrm{Mnz}=$ monazite; Mnz-PGD = monazite-bearing pegmatitic granite dyke; $\mathrm{Pl}=$ plagioclase; $\mathrm{Qz}=$ quartz; Ser $=$ sericite; Silic. $=$ silicates; $\mathrm{Zrc}=$ zircon.

Figure 9: Chemical mapping of monazite grains from the 13-AM-13 and 13-TC-5008 monazite-bearing pegmatitic granite dykes from the Lac Okaopéo region. Numbers in figures a and $\mathrm{d}$ refer to the $\mathrm{U}-\mathrm{Pb}$ dating analyses conducted using LA-ICP-MS, and reported in Table 5. a to c: BSE image with spot positions of LA-ICP-MS U-Pb dating and Ce and Th X-ray 
Turlin et al. - Unusual LREE-rich, post-tectonic, monazite- or allanite-bearing pegmatitic granites

in the central Grenville Province, Québec

maps of a representative oscillatory zoned monazite grain from the 13-AM-13 monazitebearing pegmatitic granite; $\mathrm{d}$ to f: BSE image with spot positions of LA-ICP-MS U-Pb dating and $\mathrm{Ce}$ and $\mathrm{Th} \mathrm{X}$-ray maps of a representative rather homogeneous and weakly zoned monazite grain from the 13-TC-5008 monazite-bearing pegmatitic granite. Abbreviations: $\mathrm{Mnz}=$ monazite Mnz-PGD = monazite-bearing pegmatitic granite dyke.

Figure 10: Chemical compositions of the different zones identified in monazite grains from the 13-AM-13 and 13-TC-5008 pegmatitic granite samples from the Lac Okaopéo region. a: ternary plot of the monazite compositions from the 13-AM-13 monazite-bearing pegmatitic granite. For the three identified zones, the monazite grains are dominated by monazite-(Ce) compositions, but evolve towards monazite-(La) compositions with increasing Th and $\mathrm{Si}$ proportion over LREE and $\mathrm{P} ; \mathrm{b}$ : $\mathrm{Th}+\mathrm{U}+\mathrm{Si}$ ys $\mathrm{REE}+\mathrm{Y}+\mathrm{P}$ diagram with compositional trends of huttonite and brabantite end-members for monazite grains from the 13-AM-13 pegmatitic granite. The huttonite substitution tends to be dominant with increasing Th and Si proportion over LREE and P; c: ternary plot of the monazite compositions from the 13-TC-5008 monazite-bearing pegmatitic granite. For the three identified zones, the monazite grains are clustered into the monazite-(Ce) composition field with no significant changes with increasing $\mathrm{Ti}$ and $\mathrm{Si}$ proportion over LREE and $\mathrm{P}$; $\mathrm{d}$ : $\mathrm{Th}+\mathrm{U}+\mathrm{Si}$ vs $\mathrm{REE}+\mathrm{Y}+\mathrm{P}$ diagram with compositional trends of huttonite and brabantite end-members for monazite grains from the 13-TC-5008 pegmatitic granite. Note these grains are mainly characterized by the huttonite end-member with no significant changes with increasing Ti and Si proportion over LREE and P. Abbreviations: $\mathrm{Mnz}=$ monazite; $\mathrm{PGD}=$ pegmatitic granite dyke .

Figure 11: Typical petrography of allanite-bearing pegmatitic granite dykes from the Lac Okaopéo region. a: major phases composing the allanite-bearing granite dykes (polarized and analysed light); b: allanite crystal displaying an $\mathrm{Aln}_{1}$ oscillatory zoned core corroded by an 
Turlin et al. - Unusual LREE-rich, post-tectonic, monazite- or allanite-bearing pegmatitic granites

in the central Grenville Province, Québec

$\mathrm{Aln} \mathrm{n}_{2}$ overgrowth of similar composition (Table 4) and altered by a rim associated with fluids circulation probably related to the magmatic-hydrothermal transition (polarized and analysed light); c: allanite grains display rims probably associated with the late-sericitization of feldspar. Note the syn- to late-zircon growth crystallization of the allanite phenocrysts (polarized and analysed light); d: typical millimetric allanite phenocryst from the 13-FS-1202 pegmatitic granite showing LREE-rich and Fe-Ca-LREE(Ce)-rich zones (Table 4) surrounded by an alteration rim probably associated with fluids circulation probably related to the magmatic-hydrothermal transition; e: veinlets of Ca+REE carbonates on the boundary or filling fractures of allanite crystals most probably associated with fluids circulation at the magmatic-hydrothermal transition (SEM); f: veinlets of Ca+REE silicates on the boundary or filling fractures of allanite crystals most probably associated with fluids circulation at the magmatic-hydrothermal transition (SEM). Abbreviations: Aln = allanite; Aln-PGD = allanitebearing pegmatitic granite dyke; $\mathrm{Bt}=$ biotite; Carb. = carbonates; $\mathrm{Mc}=$ microcline; $\mathrm{Pl}=$ plagioclase; $\mathrm{Qz}=$ quartz; Ser = sericite; Silic. $=$ silicates; $\mathrm{Zrc}=$ zircon .

Figure 12: Chemical compositions of the different zones identified in allanite grains from the 13-TC-5072 and 13-FS-1202 pegmatitic granite samples from the Lac Okaopéo region. a: REE vs Al composition of allanite grains from the 13-TC-5072 allanite-bearing pegmatitic granite obtained on EMP (Petrík et al., 1995). Note the clustering of compositions of the different zones close to the allanite pole; b: REE vs Al composition of allanite grains from the 13-FS-1202 allanite-bearing pegmatitic granite obtained on EMP (Petrík et al., 1995). Note the alteration trend that lead to more 'epidote like' compositions. Abbreviation: Aln = allanite; PGD = pegmatitic granite dyke.

Figure 13: Whole rock geochemistry of the REE-richest facies of the investigated pegmatitic granite dykes from the Lac Okaopéo region, compared to data of REE-rich granitic 
Turlin et al. - Unusual LREE-rich, post-tectonic, monazite- or allanite-bearing pegmatitic granites

in the central Grenville Province, Québec

pegmatites samples from Lentz (1996). a: peraluminous, metaluminous and peralkaline fields showing the peraluminous character of the pegmatitic granite samples; b: chondrite normalized REE patterns of the pegmatitic granite samples. Note that six of them display a similar tendency of strong fractionation of LREE over HREE that contrast with lower fractionation of the 13-AE-2149 dyke. The $\Sigma$ REE increases with decreasing Eu/Eu* (normalization after McDonough and Sun, 1995); c: U+Th (ppm) vs LREE (ppm) diagram showing the close relationship between an increase in REE and an increase in $\mathrm{U}$ and $\mathrm{Th}$ for all the investigated pegmatitic granite samples; $\mathrm{d}: \mathrm{Na}_{2} \mathrm{O}(w t . \%)$ vs $\mathrm{CaO}$ (wt.\%) diagram that evidence a coeval increase of $\mathrm{Na}_{2} \mathrm{O}, \mathrm{CaO}$ and the REE associated with a decrease in $\mathrm{K}_{2} \mathrm{O}$ for all the investigated pegmatitic granite samples; e: $\mathrm{Nb} / \mathrm{Ta}$ vs $\mathrm{Zr} / \mathrm{Hf}$ diagram showing a contradictory behavior of $\mathrm{Nb}$ and $\mathrm{Ta}$ between the monazite-bearing and the allanite-bearing samples, as $\mathrm{Nb} / \mathrm{Ta}$ increases with the $\Sigma \mathrm{REE}$ in the former and decreases with the $\Sigma \mathrm{REE}$ in the latter. Note that the $\mathrm{Zr} / \mathrm{Hf}$ ratio remain quite stable for both series; f: $\mathrm{CaO}$ (wt.\%) vs $\mathrm{P}_{2} \mathrm{O}_{5}$ (wt.\%) diagram showing that the formation of monazite (Mnz-bearing pegmatitic granite samples) is associated with increasing $\mathrm{CaO}$ and $\mathrm{P}_{2} \mathrm{O}_{5}$ contents. Note that the Aln-bearing pegmatitic granite samples do not display a similar pattern; g: $\mathrm{Fe}_{2} \mathrm{O}_{3}$ (total) (wt.\%) vs $\mathrm{MgO}$ (wt.\%) diagram showing that the formation of allanite (Aln-bearing pegmatitic granite samples) is associated with increasing $\mathrm{Fe}_{2} \mathrm{O}_{3}$ and $\mathrm{MgO}$ contents. Note that the Mnz-bearing pegmatitic granite samples do not display a similar pattern. Abbreviation: PGD = pegmatitic granite dyke.

Figure 14: U-Pb ages of monazite grains from the 13-AM-13 and 13-TC-5008 pegmatitic granite dykes from the Lac Okaopéo region. a: Concordia plots for the monazite grains from the 13-AM-13 pegmatitic granite ( $\mathrm{n}=25$, data-point error ellipses are $2 \sigma)$; b: Concordia plots for the over $98 \%$ of concordance analyses from the 13 -AM-13 pegmatitic granite $(\mathrm{n}=11$, 
Turlin et al. - Unusual LREE-rich, post-tectonic, monazite- or allanite-bearing pegmatitic granites

in the central Grenville Province, Québec

530 data-point error ellipses are $2 \sigma$ ); c: Concordia plots for the monazite grains from the 13-TC-

5315008 granite $(n=22$, data-point error ellipses are $2 \sigma)$.

532 
Turlin et al. - Unusual LREE-rich, post-tectonic, monazite- or allanite-bearing pegmatitic granites

in the central Grenville Province, Québec

534 Table 1: Location, present coordinates and results presented in this study of the REE

535 occurrences from the Lac Okaopéo region, first ordered by type of occurrence then from north

536 to south. Abbreviation: Aln-bearing = allanite-bearing pegmatitic granite dyke; Mnz-bearing

537 = monazite-bearing pegmatitic granite dyke; NTS = National Topographic System.

\begin{tabular}{|c|c|c|c|c|c|c|c|c|c|c|c|}
\hline \multirow[t]{2}{*}{$\begin{array}{l}\text { Type of } \\
\text { REE } \\
\text { occurren } \\
\text { ce }\end{array}$} & $\begin{array}{l}\text { Outcr } \\
\text { op n }\end{array}$ & $\begin{array}{l}\text { NTS } \\
\text { sheet }\end{array}$ & $\begin{array}{l}\text { UT } \\
\text { M } \\
\text { zone } \\
1\end{array}$ & $\begin{array}{l}\text { Eastin } \\
\mathrm{g}^{1}\end{array}$ & $\begin{array}{l}\text { Northin } \\
\mathrm{g}^{1}\end{array}$ & $\begin{array}{l}\text { Localizati } \\
\text { on (see } \\
\text { Fig. 3) }\end{array}$ & & & $\begin{array}{l}\text { Results } \\
\text { presented } \\
\text { in this } \\
\text { study }\end{array}$ & & \\
\hline & & & & & & & $\begin{array}{l}\text { Detail } \\
\text { ed } \\
\text { map }\end{array}$ & $\begin{array}{l}\text { Structur } \\
\text { al } \\
\text { measure } \\
\mathrm{s}^{2}\end{array}$ & $\begin{array}{l}\text { Whole- } \\
\text { rock } \\
\text { geochemist } \\
\text { ry }^{3}\end{array}$ & $\begin{array}{l}\text { Accessory } \\
\text { mineral } \\
\text { compositi } \\
\text { on }\end{array}$ & $\begin{array}{l}\text { Dating } \\
\text { (U-Pb } \\
\text { monazit } \\
\text { e) }\end{array}$ \\
\hline \multirow[t]{4}{*}{$\begin{array}{l}\text { Mnz- } \\
\text { bearing }\end{array}$} & $\begin{array}{l}\text { 13- } \\
\text { AM-07 }\end{array}$ & $\begin{array}{l}22 \mathrm{~K} 1 \\
0\end{array}$ & U19 & $\begin{array}{l}51019 \\
9\end{array}$ & 5620952 & $\begin{array}{l}\text { North of } \\
\text { the } \\
22 \mathrm{~K} / 10 \\
\text { NTS sheet }\end{array}$ & $\begin{array}{l}\text { Fig. A- } \\
1\end{array}$ & Fig. 5a & Table 2 & - & - \\
\hline & $\begin{array}{l}13- \\
\text { AM-10 }\end{array}$ & $\begin{array}{l}22 \mathrm{~K} 1 \\
0\end{array}$ & U19 & $\begin{array}{l}51123 \\
6\end{array}$ & 5618292 & $\begin{array}{l}\text { North of } \\
\text { the } \\
22 \mathrm{~K} / 10 \\
\text { NTS sheet }\end{array}$ & $\begin{array}{l}\text { Fig. A- } \\
3\end{array}$ & Fig. 5a & Table 2 & - & - \\
\hline & $\begin{array}{l}13- \\
\text { AM-13 }\end{array}$ & $\begin{array}{l}22 \mathrm{~K} 1 \\
0\end{array}$ & U19 & $\begin{array}{l}51205 \\
2\end{array}$ & 5614036 & $\begin{array}{l}\text { North of } \\
\text { the } \\
22 \mathrm{~K} / 10 \\
\text { NTS sheet }\end{array}$ & $\begin{array}{l}\text { Figs. 4, } \\
\text { A-5 }\end{array}$ & Fig. 5a & Table 2 & $\begin{array}{l}\text { Table } 3 \text { - } \\
\text { Figs. 10a, } \\
\text { b }\end{array}$ & $\begin{array}{l}\text { Table } 5 \\
\text { - Figs. } \\
14 a-b\end{array}$ \\
\hline & $\begin{array}{l}13- \\
\text { TC- } \\
5008\end{array}$ & $22 \mathrm{~K} 0$ & U19 & $\begin{array}{l}50461 \\
4\end{array}$ & 5585041 & $\begin{array}{l}\text { North of } \\
\text { the } \\
22 \mathrm{~K} / 07 \\
\text { NTS sheet }\end{array}$ & $\begin{array}{l}\text { Fig. A- } \\
7\end{array}$ & Fig. 5a & Table 2 & $\begin{array}{l}\text { Table } 3 \text { - } \\
\text { Figs. 10c, } \\
\text { d }\end{array}$ & $\begin{array}{l}\text { Table } 5 \\
- \text { Fig. } \\
14 \mathrm{c}\end{array}$ \\
\hline \multirow[t]{3}{*}{$\begin{array}{l}\text { Aln- } \\
\text { bearing }\end{array}$} & $\begin{array}{l}13- \\
\text { TC- } \\
5072\end{array}$ & $\begin{array}{l}22 \mathrm{~K} 1 \\
0\end{array}$ & U19 & $\begin{array}{l}51066 \\
8\end{array}$ & 5603384 & $\begin{array}{l}\text { South of } \\
\text { the } \\
22 \mathrm{~K} / 10 \\
\text { NTS sheet }\end{array}$ & $\begin{array}{l}\text { Fig. B- } \\
1\end{array}$ & Fig. 5b & Table 2 & $\begin{array}{l}\text { Table } 4 \text { - } \\
\text { Figs. 12a }\end{array}$ & - \\
\hline & $\begin{array}{l}\text { 13-FS- } \\
1202\end{array}$ & $\begin{array}{l}22 \mathrm{~K} 1 \\
0\end{array}$ & U19 & $\begin{array}{l}51016 \\
2\end{array}$ & 5601234 & $\begin{array}{l}\text { South of } \\
\text { the } \\
22 \mathrm{~K} / 10 \\
\text { NTS sheet }\end{array}$ & $\begin{array}{l}\text { Fig. B- } \\
3\end{array}$ & Fig. 5b & Table 2 & $\begin{array}{l}\text { Table } 4 \text { - } \\
\text { Figs. } 12 \mathrm{~b}\end{array}$ & - \\
\hline & $\begin{array}{l}13- \\
\text { AE- } \\
2149\end{array}$ & $\begin{array}{l}22 \mathrm{~K} 0 \\
7\end{array}$ & U19 & $\begin{array}{l}50338 \\
9\end{array}$ & 5589641 & $\begin{array}{l}\text { North of } \\
\text { the } \\
22 \mathrm{~K} / 07 \\
\text { NTS sheet }\end{array}$ & $\begin{array}{l}\text { Fig. B- } \\
5\end{array}$ & Fig. 5b & $\begin{array}{l}\text { Moukhsil et } \\
\text { al. (2014) }\end{array}$ & - & - \\
\hline
\end{tabular}

${ }^{1}$ Coordinates are reported as Universal Transverse Mercator (UTM).

$540{ }^{2}$ All the structural measurements (foliation of the host rocks and dykes) are available in 541 Appendix C.

$542{ }^{3}$ Geochemical data are represented in Fig. 13. 


\section{ACGEPTED M/ANUSCRIPT}

Turlin et al. - Unusual LREE-rich, post-tectonic, monazite- or allanite-bearing pegmatitic granites

in the central Grenville Province, Québec

545 Table 2: Whole rock geochemistry of the REE-richest facies of the pegmatitic granite dykes

546 from the Lac Okaopéo region, first ordered by type of occurrence then from north to south.

547 Data for the 13-AE-2149 pegmatitic granite is from (Moukhsil et al., 2014). Abbreviations:

$548 \mathrm{~A} / \mathrm{CNK}=\mathrm{Al} /(\mathrm{Na}+\mathrm{K}+\mathrm{Ca} / 2)(\mathrm{Shand}, 1943) ;$ Allanite-bearing $=$ allanite-bearing pegmatitic

549 granite dyke; $\mathrm{A} / \mathrm{NK}=\mathrm{Al} /(\mathrm{Na}+\mathrm{K})(\mathrm{Shand}, 1943) ; \mathrm{ASI}=$ Aluminum Saturation Index given

550 by the expression $\mathrm{ASI}=\mathrm{Al} /(\mathrm{Ca}-1.67 \times \mathrm{P}+\mathrm{Na}+\mathrm{K})$ (Frost et al., 2001; Shand, 1943);

551 Monazite-bearing = monazite-bearing pegmatitic granite dyke.

\begin{tabular}{|c|c|c|c|c|c|c|c|}
\hline $\begin{array}{l}\text { Type of REE } \\
\text { occurrence }\end{array}$ & Monazite-bearing & $\begin{array}{l}\text { Allanite- } \\
\text { bearing }\end{array}$ & & & & & \\
\hline Sample & 13-AM-07 & $\begin{array}{l}\text { 13-AM- } \\
10\end{array}$ & AM-13 & $\begin{array}{l}\text { 13-TC- } \\
5008\end{array}$ & $\begin{array}{l}\text { 13-TC- } \\
5072\end{array}$ & $\begin{array}{l}\text { 13-FS- } \\
1202\end{array}$ & $\begin{array}{l}\text { 13-AE- } \\
2149\end{array}$ \\
\hline $\mathrm{SiO}_{2}(w t . \%)$ & 71.03 & 70.80 & 60.24 & 70.79 & 70.27 & 70.85 & 55.84 \\
\hline $\mathrm{TiO}_{2}$ & 0.24 & 0.50 & 0.89 & 0.69 & 0.34 & 0.43 & 0.63 \\
\hline $\mathbf{A l}_{2} \mathbf{O}_{3}$ & 15.93 & 13.85 & 18.58 & 12.90 & 14.18 & 14.83 & 15.05 \\
\hline $\mathrm{Fe}_{2} \mathrm{O}_{3 \text { (total) }}$ & 1.23 & 1.80 & 4.60 & 3.67 & 2.38 & 3.48 & 12.42 \\
\hline MnO & 0.01 & 0.01 & 0.03 & 0.02 & 0.02 & 0.05 & 0.22 \\
\hline MgO & 0.36 & 0.48 & 1.16 & 0.71 & 0.30 & 0.52 & 0.85 \\
\hline $\mathrm{CaO}$ & 2.29 & 0.87 & 3.10 & 0.88 & 1.38 & 2.99 & 5.54 \\
\hline $\mathrm{Na}_{2} \mathrm{O}$ & 3.53 & 2.26 & 4.02 & 1.99 & 2.74 & 4.14 & 4.28 \\
\hline $\mathbf{K}_{2} \mathbf{O}$ & 4.32 & 6.68 & 4.36 & 6.25 & 5.90 & 1.33 & 1.93 \\
\hline $\mathrm{P}_{2} \mathrm{O}_{5}$ & 0.29 & 0.09 & 0.40 & 0.10 & 0.15 & 0.02 & 0.22 \\
\hline $\mathrm{Cr}_{2} \mathrm{O}_{3}$ & $<0.01$ & $<0.01$ & $<0.01$ & $<0.01$ & $<0.01$ & $<0.01$ & $<0.01$ \\
\hline LOI & 0.63 & 0.92 & 0.82 & 0.60 & 0.73 & 1.01 & 0.83 \\
\hline Total & 99.87 & 98.26 & 98.19 & 98.58 & 98.39 & 99.64 & 97.80 \\
\hline ASI & 1.30 & 1.19 & 1.36 & 1.20 & 1.18 & 1.35 & 1.08 \\
\hline A/CNK & 1.28 & 1.30 & 1.27 & 1.29 & 1.24 & 1.30 & 0.87 \\
\hline A/NK & 2.03 & 1.55 & 2.22 & 1.57 & 1.64 & 2.71 & 2.42 \\
\hline $\mathrm{Sr}(p p m)$ & 448.00 & 342.00 & 550.00 & 213.00 & 164.00 & 275.00 & 147.00 \\
\hline $\mathbf{B a}$ & 1191.00 & 2424.00 & 899.00 & 1662.00 & 661.00 & 147.00 & 181.00 \\
\hline $\mathbf{N b}$ & 5.60 & 8.40 & 21.00 & 15.70 & 7.50 & 17.30 & 132.00 \\
\hline $\mathbf{V}$ & 16.00 & 23.00 & 27.00 & 27.00 & 7.00 & 15.00 & 38.00 \\
\hline Co & 2.00 & 2.00 & 6.00 & 5.00 & 2.00 & 3.00 & 6.00 \\
\hline Ga & 39.00 & 22.00 & 60.00 & 26.00 & 29.00 & 53.00 & 79.00 \\
\hline Ge & 4.70 & 2.10 & 6.90 & 2.40 & 2.90 & 7.40 & 9.70 \\
\hline In & $<0.1$ & $<0.1$ & $<0.1$ & $<0.1$ & $<0.1$ & $<0.1$ & 0.20 \\
\hline Sn & $<1$ & $<1$ & $<1$ & $<1$ & $<1$ & 2.00 & 4.00 \\
\hline Cs & 0.50 & 0.70 & 1.50 & 0.70 & 0.30 & 1.00 & 0.70 \\
\hline $\mathbf{P b}$ & 35.00 & 29.00 & 34.00 & 22.00 & 31.00 & 17.00 & 41.00 \\
\hline Be & 2.00 & $<1$ & 3.00 & $<1$ & $<1$ & 4.00 & 9.00 \\
\hline Hf & 23.40 & 4.40 & 41.50 & 9.00 & 7.40 & 50.80 & 171.00 \\
\hline Ta & 0.10 & 0.25 & 0.40 & 0.35 & 0.11 & 0.30 & 3.20 \\
\hline $\mathbf{W}$ & 0.90 & 0.80 & 1.10 & 0.80 & 1.40 & 0.80 & 3.00 \\
\hline
\end{tabular}


Turlin et al. - Unusual LREE-rich, post-tectonic, monazite- or allanite-bearing pegmatitic granites

in the central Grenville Province, Québec

\begin{tabular}{|c|c|c|c|c|c|c|c|}
\hline TI & 0.97 & 1.08 & 1.40 & 1.10 & 0.97 & 0.75 & 0.34 \\
\hline $\mathbf{B i}$ & $<0.1$ & $<0.1$ & $<0.1$ & $<0.1$ & $<0.1$ & $<0.1$ & $<0.1$ \\
\hline Th & 561.00 & 102.00 & 1300.00 & 123.00 & 70.50 & 392.00 & 766.00 \\
\hline $\mathbf{U}$ & 11.00 & 2.02 & 19.10 & 1.66 & 1.11 & 6.88 & 30.30 \\
\hline $\mathbf{R b}$ & 98.00 & 141.00 & 214.00 & 172.00 & 122.00 & 58.00 & 42.00 \\
\hline $\mathbf{Y}$ & 29.50 & 5.90 & 52.90 & 10.00 & 15.80 & 83.50 & 544.00 \\
\hline $\mathbf{Z r}$ & 860.00 & 195.00 & 1480.00 & 388.00 & 290.00 & 1760.00 & 6340.00 \\
\hline $\mathrm{Nb} / \mathrm{Ta}$ & 56 & 34 & 53 & 45 & 68 & 58 & 41 \\
\hline Zr/Hf & 37 & 44 & 36 & 43 & 39 & 35 & 37 \\
\hline$T h / U$ & 51 & 50 & 68 & 74 & 64 & 57 & 25 \\
\hline La & 1560.00 & 433.00 & 1800.00 & 538.00 & 674.00 & 1870.00 & 2150.00 \\
\hline $\mathrm{Ce}$ & 2720.00 & 690.00 & 3370.00 & 884.00 & 1160.00 & 3580.00 & 4130.00 \\
\hline Pr & 271.00 & 64.10 & 370.00 & 92.20 & 120.00 & 406.00 & 470.00 \\
\hline Nd & 843.00 & 202.00 & 1250.00 & 300.00 & 377.00 & 1400.00 & 1710.00 \\
\hline Sm & 84.60 & 17.50 & 159.00 & 30.40 & 37.70 & 179.00 & 297.00 \\
\hline Eu & 3.47 & 2.37 & 4.74 & 2.40 & 2.62 & 4.71 & 9.39 \\
\hline Gd & 28.60 & 5.70 & 65.20 & 11.80 & 13.00 & 73.30 & 180.00 \\
\hline Tb & 2.07 & 0.41 & 5.03 & 0.78 & 1.09 & 6.81 & 24.90 \\
\hline Dy & 8.41 & 1.55 & 16.30 & 2.99 & 4.33 & 25.70 & 123.00 \\
\hline Ho & 1.12 & 0.22 & 1.93 & 0.43 & 0.67 & 3.58 & 21.80 \\
\hline Er & 2.42 & 0.52 & 3.81 & 0.91 & 1.51 & 7.73 & 59.00 \\
\hline Tm & 0.23 & 0.06 & 0.35 & 0.09 & 0.17 & 0.90 & 8.34 \\
\hline $\mathbf{Y b}$ & 1.13 & 0.35 & 1.56 & 0.43 & 0.74 & 4.87 & 51.80 \\
\hline $\mathbf{L u}$ & 0.17 & 0.05 & 0.22 & 0.06 & 0.10 & 0.72 & 7.22 \\
\hline ¿LREE & 5479 & 1407 & 6949 & 1845 & 2369 & 7435 & 8757 \\
\hline इHREE & 47 & 11 & 99 & 19 & 24 & 128 & 485 \\
\hline इREE & 5526 & 1418 & 7048 & 1864 & 2393 & 7563 & 9242 \\
\hline $\mathbf{L a}_{\mathbb{N}} / \mathbf{Y b}_{\mathbf{N}}{ }^{1}$ & 938 & 840 & 784 & 850 & 619 & 261 & 28 \\
\hline $\mathbf{E u} / \mathbf{E} \mathbf{u}^{* 1}$ & 0.22 & 0.72 & 0.14 & 0.39 & 0.36 & 0.13 & 0.12 \\
\hline Cd & $<0.5$ & $<0.5$ & $<0.5$ & $<0.5$ & $<0.5$ & $<0.5$ & $<0.5$ \\
\hline $\mathbf{C u}$ & 5.00 & 3.00 & 20.00 & 2.00 & 2.00 & 6.00 & 16.00 \\
\hline $\mathbf{A g}$ & $<0.3$ & $<0.3$ & $<0.3$ & $<0.3$ & $<0.3$ & 3.60 & - \\
\hline $\mathbf{N i}$ & $<1$ & $<1$ & 3.00 & 2.00 & $<1$ & $<1$ & 3.00 \\
\hline Mo & 2.00 & $<1$ & 4.00 & 1.00 & 5.00 & $<1$ & 6.00 \\
\hline$\overline{Z n}$ & 27.00 & 32.00 & 110.00 & 103.00 & 46.00 & 56.00 & 288.00 \\
\hline $\mathbf{S}$ & 300.00 & 300.00 & 1100.00 & 100.00 & $<100$ & 300.00 & 600.00 \\
\hline$\overline{\mathbf{A u}}$ & $<2$ & $<2$ & $<2$ & $<2$ & $<2$ & $<2$ & $<2$ \\
\hline
\end{tabular}


Turlin et al. - Unusual LREE-rich, post-tectonic, monazite- or allanite-bearing pegmatitic granites

in the central Grenville Province, Québec

\begin{tabular}{|l|l|l|l|l|l|l|l|}
\hline As & $<0.5$ & $<0.5$ & $<0.5$ & $<0.5$ & 3.30 & $<0.5$ & $<0.5$ \\
\hline $\mathbf{B r}$ & $<0.5$ & $<0.5$ & $<0.5$ & $<0.5$ & $<0.5$ & $<0.5$ & $<0.5$ \\
\hline $\mathbf{C r}$ & 58.00 & 47.00 & 70.00 & 49.00 & 59.00 & 75.00 & 48.00 \\
\hline $\mathbf{I r}$ & $<5$ & $<5$ & $<5$ & $<5$ & $<5$ & $<5$ & $<5$ \\
\hline $\mathbf{S c}$ & 1.10 & 1.70 & 3.50 & 1.70 & 2.60 & 6.70 & 31.90 \\
\hline $\mathbf{S b}$ & $<0.1$ & $<0.1$ & $<0.1$ & $<0.1$ & $<0.1$ & $<0.1$ & $<0.1$ \\
\hline Se & $<3$ & $<3$ & $<3$ & $<3$ & $<3$ & $<3$ & $<3$ \\
\hline
\end{tabular}

${ }^{1}$ Normalization after McDonough and Sun (1995). 
Turlin et al. - Unusual LREE-rich, post-tectonic, monazite- or allanite-bearing pegmatitic granites

in the central Grenville Province, Québec

554 Table 3: Analyses of monazite grains from the 13-AM-13 and the 13-TC-5008 pegmatitic

555 granite dykes from the Lac Okaopéo region. Data were obtained using EMP and were

556 performed on LREE-rich, intermediate and Th-Si-rich zones of monazite grains. They are

557 reported with confidence interval of $95 \%$ in brackets $(n=$ number of analyses). Abbreviations:

558 Brab. = brabantite; Hutt. = huttonite; Mnz. = monazite; Xen. = xenotime

\begin{tabular}{|c|c|c|c|c|c|c|c|}
\hline \multirow{2}{*}{$\begin{array}{l}\text { Sample } \\
\text { Zonation type }\end{array}$} & & \multicolumn{3}{|c|}{ 13-AM-13 } & \multicolumn{3}{|c|}{$13-T C-5008$} \\
\hline & & LREE(Ce)-rich & Intermediate & Th-Si-rich & LREE(Ce)-rich & nediate & Th-Si-rich \\
\hline \multirow[t]{27}{*}{ Oxides/wt.\% } & $\mathrm{P}_{2} \mathrm{O}_{5}$ & 29.07 & 27.59 & 25.63 & 28.99 & 28.87 & 28.43 \\
\hline & & $(0.22)$ & $(0.33)$ & $(0.40)$ & $(0.17)$ & $(0.10)$ & $(0.20)$ \\
\hline & $\mathrm{SiO}_{2}$ & 0.99 & 1.92 & 3.14 & 1.03 & 1.09 & 1.38 \\
\hline & & $(0.12)$ & $(0.19)$ & $(0.24)$ & (0.11) & $(0.05)$ & $(0.14)$ \\
\hline & $\mathrm{CaO}$ & 0.89 & 0.93 & 0.89 & 0.31 & 0.31 & 0.37 \\
\hline & & $(0.15)$ & $(0.11)$ & $(0.12)$ & $(0.03)$ & $(0.02)$ & $(0.03)$ \\
\hline & $\mathrm{Y}_{2} \mathrm{O}_{3}$ & 0.26 & 0.17 & 0.10 & 0.09 & 0.07 & 0.08 \\
\hline & & $(0.06)$ & $(0.03)$ & $(0.02)$ & (0.04) & $(0.02)$ & $(0.05)$ \\
\hline & $\mathrm{La}_{2} \mathrm{O}_{3}$ & 15.59 & 14.48 & 14.04 & 17.98 & 18.07 & 17.91 \\
\hline & & $(0.38)$ & $(0.16)$ & $(0.17)$ & $(0.18)$ & $(0.12)$ & $(0.25)$ \\
\hline & $\mathrm{Ce}_{2} \mathrm{O}_{3}$ & & 28.57 & 26.69 & 31.88 & 31.77 & 31.07 \\
\hline & & $(0.50)$ & $(0.32)$ & $(0.34)$ & $(0.25)$ & $(0.15)$ & $(0.29)$ \\
\hline & $\mathrm{Pr}_{2} \mathrm{O}_{3}$ & 3.47 & 3.30 & 3.04 & 3.39 & 3.37 & 3.30 \\
\hline & & $(0.04)$ & $(0.04)$ & $(0.05)$ & $(0.05)$ & $(0.04)$ & $(0.05)$ \\
\hline & $\mathrm{Nd}_{2}$ & 10.83 & 10.52 & 9.43 & 10.62 & 10.53 & 10.28 \\
\hline & & $(0.09)$ & $(0.16)$ & $(0.17)$ & (0.16) & $(0.11)$ & $(0.22)$ \\
\hline & $\mathrm{Sm}_{2} \mathrm{O}_{3}$ & 1.40 & 1.34 & 1.07 & 1.10 & 1.09 & 1.05 \\
\hline & & $(0.08)$ & $(0.06)$ & $(0.05)$ & $(0.05)$ & $(0.03)$ & $(0.06)$ \\
\hline & $\mathrm{Gd}_{2} \mathrm{O}_{3}$ & 0.67 & 0.63 & 0.47 & 0.44 & 0.45 & 0.43 \\
\hline & & $(0.06)$ & $(0.03)$ & $(0.03)$ & (0.04) & $(0.02)$ & $(0.05)$ \\
\hline & $\mathrm{PbO}$ & 0.57 & 0.44 & 0.95 & 0.02 & 0.01 & 0.07 \\
\hline & & $(0.22)$ & $(0.18)$ & $(0.20)$ & (0.03) & $(0.02)$ & $(0.13)$ \\
\hline & $\mathrm{ThO}_{2}$ & 7.06 & 11.07 & 15.93 & 4.57 & 4.85 & 6.19 \\
\hline & & $(0.46)$ & $(0.68)$ & $(0.80)$ & $(0.48)$ & $(0.24)$ & $(0.52)$ \\
\hline & $\mathrm{UO}_{2}$ & 0.10 & 0.11 & 0.10 & 0.05 & 0.05 & 0.07 \\
\hline & & $(0.01)$ & $(0.01)$ & $(0.01)$ & $(0.01)$ & $(0.01)$ & $(0.02)$ \\
\hline & Total & 101.34 & 101.07 & 101.49 & 100.48 & 100.52 & 100.63 \\
\hline
\end{tabular}


Turlin et al. - Unusual LREE-rich, post-tectonic, monazite- or allanite-bearing pegmatitic granites

in the central Grenville Province, Québec

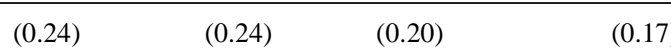

$(0.12)$

$(0.15)$

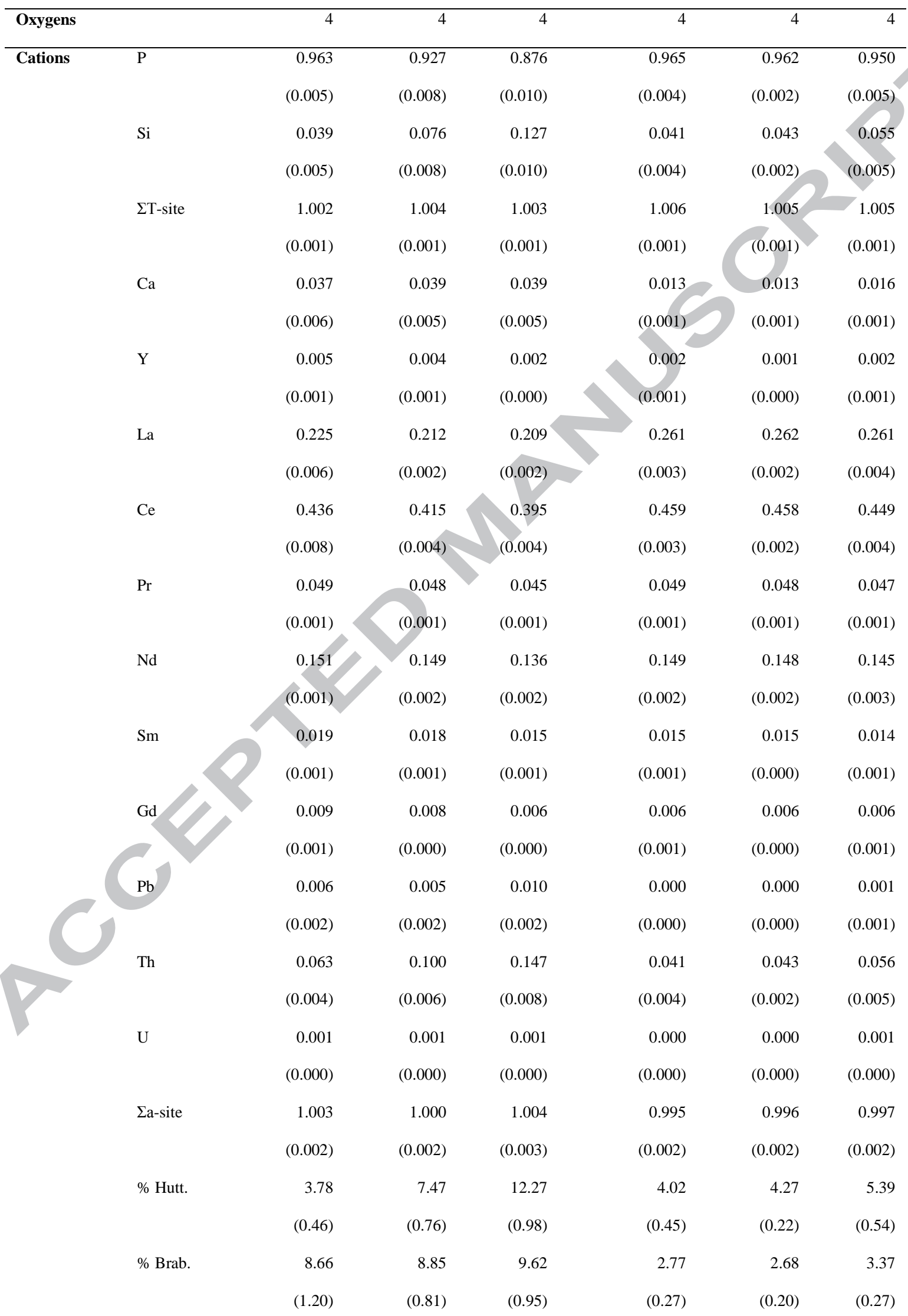


Turlin et al. - Unusual LREE-rich, post-tectonic, monazite- or allanite-bearing pegmatitic granites

in the central Grenville Province, Québec

$\begin{array}{lrrrrrr}\text { \% Mnz. } & 87.56 & 83.68 & 78.11 & 93.21 & 93.05 & 91.24 \\ + \text { Xen. } & (0.92) & (0.85) & (0.96) & (0.48) & (0.27) & (0.53) \\ \mathrm{n} & 20 & 23 & 29 & 17 & 27 & 22\end{array}$

559

560 
Turlin et al. - Unusual LREE-rich, post-tectonic, monazite- or allanite-bearing pegmatitic granites

in the central Grenville Province, Québec

561 Table 4: Analyses of allanite grains from the 13-TC-5072 and 13-FS-1202 pegmatitic granite

562 dykes from the Lac Okaopéo region. Data were obtained using EMP and were performed on

563 LREE(Ce)-rich zones, intermediate zones and alteration rims of allanite grains from the 13-

564 TC-5072 pegmatitic granite, and on LREE(Ce)-rich zones, Fe-Ca-LREE(Ce)-rich zones and

565 alteration rims of allanite grains from the 13-FS-1202 pegmatitic granite. They are reported

566 with confidence interval of $95 \%$ in brackets $(n=$ number of analyses $)$. Abbreviations: Aln $=$

567 allanite.

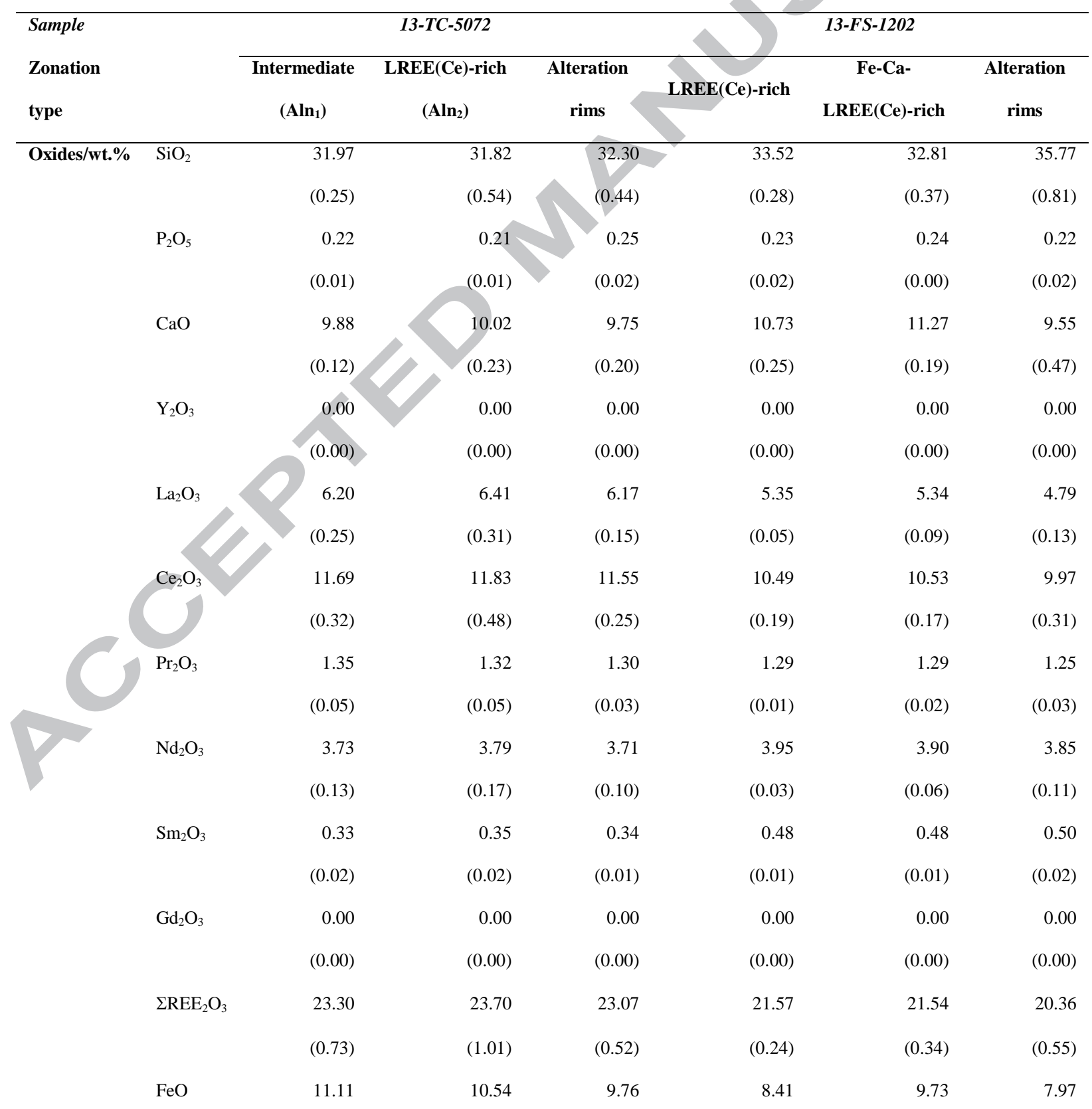


Turlin et al. - Unusual LREE-rich, post-tectonic, monazite- or allanite-bearing pegmatitic granites in the central Grenville Province, Québec

\begin{tabular}{|c|c|c|c|c|c|c|c|}
\hline & & $(0.94)$ & $(0.36)$ & $(0.31)$ & $(0.21)$ & $(0.28)$ & $(0.47)$ \\
\hline & \multirow[t]{2}{*}{$\mathrm{K}_{2} \mathrm{O}$} & 0.01 & 0.02 & 0.03 & 0.01 & 0.02 & 0.03 \\
\hline & & $(0.01)$ & $(0.00)$ & $(0.01)$ & $(0.00)$ & $(0.01)$ & $(0.01)$ \\
\hline & \multirow[t]{2}{*}{$\mathrm{MgO}$} & 0.43 & 0.34 & 0.33 & 0.31 & 0.41 & 0.35 \\
\hline & & $(0.12)$ & $(0.03)$ & $(0.03)$ & $(0.04)$ & $(0.05)$ & \\
\hline & \multirow[t]{2}{*}{$\mathrm{Al}_{2} \mathrm{O}_{3}$} & 18.94 & 18.63 & 18.92 & 18.88 & 18.44 & 18.93 \\
\hline & & $(0.53)$ & $(0.22)$ & $(0.25)$ & $(0.17)$ & $(0.19)$ & $(0.36)$ \\
\hline & \multirow[t]{2}{*}{$\mathrm{TiO}_{2}$} & 0.95 & 0.92 & 1.05 & 0.85 & 0.81 & 0.95 \\
\hline & & $(0.06)$ & $(0.04)$ & $(0.07)$ & $(0.03)$ & (0.04) & $(0.07)$ \\
\hline & \multirow[t]{2}{*}{$\mathrm{MnO}$} & 0.27 & 0.29 & 0.30 & 0.34 & 0.30 & 0.33 \\
\hline & & $(0.07)$ & $(0.03)$ & $(0.02)$ & $(0,0)$ & $(0.01)$ & $(0.02)$ \\
\hline & \multirow[t]{2}{*}{$\mathrm{SrO}$} & 0.09 & 0.13 & 0.14 & 0.26 & 0.23 & 0.25 \\
\hline & & $(0.04)$ & $(0.02)$ & $(0.02)$ & (0.01) & $(0.01)$ & $(0.03)$ \\
\hline & \multirow[t]{2}{*}{$\mathrm{PbO}$} & 0.04 & 0.04 & 0.04 & 0.03 & 0.04 & 0.04 \\
\hline & & $(0.00)$ & $(0.00)$ & $(0.01)$ & $(0.00)$ & $(0.00)$ & $(0.00)$ \\
\hline & \multirow[t]{2}{*}{$\mathrm{ThO}_{2}$} & 0.69 & 0.62 & 0.73 & 1.12 & 1.00 & 1.19 \\
\hline & & $(0.06)$ & $(0.04)$ & $(0.04)$ & $(0.04)$ & $(0.07)$ & $(0.08)$ \\
\hline & \multirow[t]{2}{*}{$\mathrm{UO}_{2}$} & 0.01 & 0.01 & 0.01 & 0.01 & 0.01 & 0.01 \\
\hline & & $(0.01)$ & .0 & $(0.00)$ & $(0.00)$ & $(0.00)$ & $(0.00)$ \\
\hline & \multirow[t]{2}{*}{$\mathrm{F}$} & 0.46 & 0.70 & 0.63 & 0.52 & 0.55 & 0.44 \\
\hline & & (0.11) & $(0.21)$ & $(0.09)$ & $(0.02)$ & $(0.02)$ & $(0.03)$ \\
\hline & \multirow[t]{2}{*}{ Total } & 98.37 & 97.98 & 97.31 & 96.79 & 97.38 & 96.39 \\
\hline & & $(0.88)$ & $(0.35)$ & $(0.45)$ & $(0.28)$ & $(0.27)$ & $(0.85)$ \\
\hline Oxygens & & 12.5 & 12.5 & 12.5 & 12.5 & 12.5 & 12.5 \\
\hline \multirow{4}{*}{\multicolumn{2}{|c|}{ Cations }} & 2.968 & 2.961 & 2.999 & 3.090 & 3.033 & 3.240 \\
\hline & & $(0.021)$ & $(0.038)$ & $(0.024)$ & $(0.020)$ & $(0.022)$ & $(0.051)$ \\
\hline & & 0.017 & 0.017 & 0.019 & 0.018 & 0.019 & 0.017 \\
\hline & & $(0.001)$ & $(0.000)$ & $(0.002)$ & $(0.001)$ & $(0.000)$ & $(0.001)$ \\
\hline & \multirow[t]{2}{*}{$\mathrm{Ca}$} & 0.983 & 0.999 & 0.971 & 1.061 & 1.119 & 0.929 \\
\hline & & $(0.016)$ & $(0.020)$ & $(0.022)$ & $(0.025)$ & $(0.022)$ & $(0.047)$ \\
\hline & \multirow[t]{2}{*}{$\mathrm{Y}$} & 0.000 & 0.000 & 0.000 & 0.000 & 0.000 & 0.000 \\
\hline & & $(0.000)$ & $(0.000)$ & $(0.000)$ & $(0.000)$ & $(0.000)$ & $(0.000)$ \\
\hline & \multirow[t]{2}{*}{$\mathrm{La}$} & 0.212 & 0.220 & 0.212 & 0.182 & 0.182 & 0.161 \\
\hline & & $(0.009)$ & $(0.012)$ & $(0.006)$ & $(0.002)$ & $(0.003)$ & $(0.005)$ \\
\hline & \multirow[t]{2}{*}{$\mathrm{Ce}$} & 0.397 & 0.404 & 0.393 & 0.354 & 0.357 & 0.332 \\
\hline & & $(0.011)$ & $(0.019)$ & $(0.010)$ & $(0.007)$ & $(0.006)$ & $(0.012)$ \\
\hline
\end{tabular}


Turlin et al. - Unusual LREE-rich, post-tectonic, monazite- or allanite-bearing pegmatitic granites in the central Grenville Province, Québec

\begin{tabular}{|c|c|c|c|c|c|c|}
\hline \multirow[t]{2}{*}{$\operatorname{Pr}$} & 0.046 & 0.045 & 0.044 & 0.043 & 0.044 & 0.041 \\
\hline & $(0.002)$ & $(0.002)$ & $(0.001)$ & $(0.001)$ & $(0.001)$ & $(0.001)$ \\
\hline \multirow[t]{2}{*}{$\mathrm{Nd}$} & 0.124 & 0.126 & 0.123 & 0.130 & 0.129 & 0.125 \\
\hline & $(0.004)$ & $(0.006)$ & $(0.004)$ & $(0.001)$ & $(0.002)$ & $(0.004)$ \\
\hline \multirow[t]{2}{*}{$\mathrm{Sm}$} & 0.010 & 0.011 & 0.011 & 0.015 & 0.015 & 0.015 \\
\hline & $(0.001)$ & $(0.001)$ & $(0.000)$ & $(0.000)$ & $(0.000)$ & $(0.001)$ \\
\hline \multirow[t]{2}{*}{$\mathrm{Gd}$} & 0.000 & 0.000 & 0.000 & 0.000 & 0.000 & 0.000 \\
\hline & $(0.000)$ & $(0.000)$ & $(0.000)$ & $(0.000)$ & 0000 & $(0.000)$ \\
\hline \multirow[t]{2}{*}{$\Sigma \mathrm{REE}$} & 0.789 & 0.806 & 0.783 & 0.725 & 0.727 & 0.675 \\
\hline & $(0.025)$ & $(0.039)$ & $(0.020)$ & $(0.009)$ & $(0.012)$ & $(0.021)$ \\
\hline \multirow[t]{2}{*}{$\mathrm{Fe}$} & 0.862 & 0.820 & 0.759 & 0.649 & 0.754 & 0.605 \\
\hline & $(0.073)$ & $(0.026)$ & $(0.025)$ & (0.017) & $(0.023)$ & $(0.036)$ \\
\hline \multirow[t]{2}{*}{ K } & 0.002 & 0.002 & 0.004 & 0.002 & 0.002 & 0.004 \\
\hline & $(0.001)$ & $(0.001)$ & $(0.001)$ & $(0.000)$ & $(0.001)$ & $(0.001)$ \\
\hline \multirow[t]{2}{*}{$\mathrm{Mg}$} & 0.059 & 0.048 & 0.046 & 0.042 & 0.056 & 0.047 \\
\hline & $(0.017)$ & $(0.005)$ & (0.004) & $(0.006)$ & $(0.007)$ & $(0.009)$ \\
\hline \multirow[t]{2}{*}{$\mathrm{Al}$} & 2.072 & 2.044 & 2.071 & 2.050 & 2.010 & 2.024 \\
\hline & $(0.053)$ & $(0.018)$ & $(0.018)$ & $(0.015)$ & $(0.018)$ & $(0.035)$ \\
\hline \multirow[t]{2}{*}{$\mathrm{Ti}$} & 0.066 & .065 & 0.073 & 0.059 & 0.056 & 0.065 \\
\hline & $(0.004)$ & $(0.003)$ & $(0.005)$ & $(0.002)$ & $(0.003)$ & $(0.005)$ \\
\hline \multirow[t]{2}{*}{$\mathrm{Mn}$} & 0.021 & 0.023 & 0.024 & 0.027 & 0.023 & 0.025 \\
\hline & $(0.005)$ & $(0.003)$ & $(0.002)$ & $(0.002)$ & $(0.001)$ & $(0.002)$ \\
\hline \multirow[t]{4}{*}{$\mathrm{Sr}$} & 0.005 & 0.007 & 0.008 & 0.014 & 0.012 & 0.013 \\
\hline & $(0.002)$ & $(0.001)$ & $(0.001)$ & $(0.001)$ & $(0.001)$ & $(0.002)$ \\
\hline & 0.001 & 0.001 & 0.001 & 0.001 & 0.001 & 0.001 \\
\hline & $(0.000)$ & $(0.000)$ & $(0.000)$ & $(0.000)$ & $(0.000)$ & $(0.000)$ \\
\hline \multirow[t]{2}{*}{ Th } & 0.015 & 0.013 & 0.015 & 0.024 & 0.021 & 0.025 \\
\hline & $(0.001)$ & $(0.001)$ & $(0.001)$ & $(0.001)$ & $(0.002)$ & $(0.002)$ \\
\hline \multirow[t]{2}{*}{$\mathrm{U}$} & 0.000 & 0.000 & 0.000 & 0.000 & 0.000 & 0.000 \\
\hline & $(0.000)$ & $(0.000)$ & $(0.000)$ & $(0.000)$ & $(0.000)$ & $(0.000)$ \\
\hline \multirow[t]{2}{*}{$\mathrm{F}$} & 0.135 & 0.207 & 0.185 & 0.153 & 0.160 & 0.127 \\
\hline & $(0.032)$ & $(0.063)$ & $(0.028)$ & $(0.006)$ & $(0.006)$ & $(0.009)$ \\
\hline \multirow[t]{2}{*}{ Total } & 7.996 & 8.012 & 7.958 & 7.913 & 7.994 & 7.994 \\
\hline & $(0.027)$ & $(0.022)$ & $(0.023)$ & $(0.019)$ & $(0.018)$ & $(0.018)$ \\
\hline $\mathrm{n}$ & 14 & 26 & 47 & 91 & 122 & 52 \\
\hline
\end{tabular}


Turlin et al. - Unusual LREE-rich, post-tectonic, monazite- or allanite-bearing pegmatitic granites

in the central Grenville Province, Québec

569 
Turlin et al. - Unusual LREE-rich, post-tectonic, monazite- or allanite-bearing pegmatitic granites

in the central Grenville Province, Québec

570 Table 5: U-Pb monazite dating using LA-ICP-MS from the 13-AM-13 and 13-TC-5008

571 monazite-bearing pegmatitic granite dykes from the Lac Okaopéo region. Abbreviations:

572 Conc. $(\%)=$ degree of concordance.

\begin{tabular}{|c|c|c|c|c|c|c|c|c|c|c|c|c|}
\hline $\begin{array}{l}\text { Sampl } \\
\text { e }\end{array}$ & $\begin{array}{l}\text { Analysi } \\
\text { s no. }\end{array}$ & $\begin{array}{l}\text { Isotopic } \\
\text { ratios }\end{array}$ & $\begin{array}{l}\text { Ages / } \\
\text { Ma }\end{array}$ & & & & & & & & 7 & \\
\hline & & $\begin{array}{l}{ }^{206} \mathbf{P b} /{ }^{238} \\
\mathrm{U}\end{array}$ & $1 \sigma$ & $\begin{array}{l}{ }^{207} \mathrm{~Pb} /{ }^{235} \\
\mathrm{U}\end{array}$ & $1 \sigma$ & $\begin{array}{l}{ }^{207} \mathbf{P b} /{ }^{206} \mathbf{P} \\
\text { b }\end{array}$ & $1 \sigma$ & $\begin{array}{l}{ }^{206} \mathbf{P b} / /^{238} \\
\mathrm{U}\end{array}$ & $1 \sigma$ & $\begin{array}{l}{ }^{207} \mathrm{~Pb} /{ }^{235} \\
\mathrm{U}\end{array}$ & $1 \sigma$ & $\begin{array}{l}\text { Conc } \\
.(\%)\end{array}$ \\
\hline \multirow[t]{13}{*}{$\begin{array}{l}13- \\
A M-13\end{array}$} & $1-1$ & 0.1641 & $\begin{array}{l}0.002 \\
0\end{array}$ & 1.645 & $\begin{array}{l}0.02 \\
2\end{array}$ & 1006.2 & $\begin{array}{l}24.6 \\
2\end{array}$ & 979.3 & $\begin{array}{l}10 . \\
9\end{array}$ & 987.6 & 8.6 & 98.2 \\
\hline & $1-2$ & 0.1589 & $\begin{array}{l}0.001 \\
9\end{array}$ & 1.593 & $\begin{array}{l}0.02 \\
1\end{array}$ & 1005.2 & 23.8 & 950.9 & $\begin{array}{l}10 . \\
6\end{array}$ & 967.4 & 8.3 & 96.2 \\
\hline & $1-3$ & 0.1646 & $\begin{array}{l}0.002 \\
0\end{array}$ & 1.650 & $\begin{array}{l}0.02 \\
2\end{array}$ & 1005.5 & $\begin{array}{l}24.1 \\
2\end{array}$ & 982.3 & $\begin{array}{l}11 . \\
0\end{array}$ & 989.5 & 8.5 & 98.4 \\
\hline & $1-4$ & 0.1620 & $\begin{array}{l}0.002 \\
0\end{array}$ & 1.628 & $\begin{array}{l}0.02 \\
4\end{array}$ & 1010.8 & $\begin{array}{l}27.5 \\
8\end{array}$ & 967.8 & $\begin{array}{l}10 . \\
9\end{array}$ & 981.1 & 9.4 & 97.1 \\
\hline & $1-5$ & 0.1560 & $\begin{array}{l}0.001 \\
9\end{array}$ & 1.564 & $\begin{array}{l}0.02 \\
0\end{array}$ & 1006.6 & $\begin{array}{l}22.9 \\
7\end{array}$ & 934.4 & $\begin{array}{l}10 . \\
4\end{array}$ & 956.1 & 8.0 & 95.0 \\
\hline & $2-1$ & 0.1640 & $\begin{array}{l}0.002 \\
0\end{array}$ & 1.641 & $\begin{array}{l}0.02 \\
1\end{array}$ & 1001.1 & $\begin{array}{l}22.5 \\
4\end{array}$ & 979.1 & $\begin{array}{l}10 . \\
9\end{array}$ & 985.9 & 8.1 & 98.5 \\
\hline & $2-2$ & 0.15 & $\begin{array}{l}0.001 \\
9\end{array}$ & 1.571 & $\begin{array}{l}0.02 \\
0\end{array}$ & 997.4 & $\begin{array}{l}22.4 \\
8\end{array}$ & 941.9 & $\begin{array}{l}10 . \\
5\end{array}$ & 958.7 & 7.9 & 96.1 \\
\hline & $2-3$ & 0.1626 & $\begin{array}{l}0.002 \\
0\end{array}$ & 1.630 & $\begin{array}{l}0.02 \\
2\end{array}$ & 1004.8 & $\begin{array}{l}23.5 \\
9\end{array}$ & 971.5 & $\begin{array}{l}10 . \\
8\end{array}$ & 981.7 & 8.3 & 97.7 \\
\hline & $2-4$ & 0.1666 & $\begin{array}{l}0.002 \\
0\end{array}$ & 1.671 & $\begin{array}{l}0.02 \\
4\end{array}$ & 1007.5 & $\begin{array}{l}26.0 \\
5\end{array}$ & 993.1 & $\begin{array}{l}11 . \\
2\end{array}$ & 997.6 & 9.1 & 99.0 \\
\hline & $2-5$ & 0.1595 & $\begin{array}{l}0.001 \\
9\end{array}$ & 1.597 & $\begin{array}{l}0.02 \\
2\end{array}$ & 1003.7 & $\begin{array}{l}24.5 \\
7\end{array}$ & 953.7 & $\begin{array}{l}10 . \\
7\end{array}$ & 968.9 & 8.5 & 96.5 \\
\hline & 3-1 & 0.1687 & $\begin{array}{l}0.002 \\
0\end{array}$ & 1.703 & $\begin{array}{l}0.02 \\
4\end{array}$ & 1019.6 & $\begin{array}{l}25.5 \\
9\end{array}$ & 1005.2 & $\begin{array}{l}11 . \\
3\end{array}$ & 1009.7 & 9.0 & 99.0 \\
\hline & $3-2$ & 0.1601 & $\begin{array}{l}0.001 \\
9\end{array}$ & 1.605 & $\begin{array}{l}0.02 \\
1\end{array}$ & 1005.2 & $\begin{array}{l}22.8 \\
9\end{array}$ & 957.5 & $\begin{array}{l}10 . \\
7\end{array}$ & 972.1 & 8.1 & 96.7 \\
\hline & 4 4-1 & 0.1587 & $\begin{array}{l}0.001 \\
9\end{array}$ & 1.590 & $\begin{array}{l}0.02 \\
1\end{array}$ & 1005.0 & $\begin{array}{l}23.1 \\
9\end{array}$ & 949.4 & $\begin{array}{l}10 . \\
6\end{array}$ & 966.3 & 8.1 & 96.1 \\
\hline
\end{tabular}


Turlin et al. - Unusual LREE-rich, post-tectonic, monazite- or allanite-bearing pegmatitic granites

in the central Grenville Province, Québec

\begin{tabular}{|c|c|c|c|c|c|c|c|c|c|c|c|c|}
\hline & $4-2$ & 0.1606 & $\begin{array}{l}0.001 \\
9\end{array}$ & 1.608 & $\begin{array}{l}0.02 \\
1\end{array}$ & 1004.1 & $\begin{array}{l}23.3 \\
1\end{array}$ & 959.9 & $\begin{array}{l}10 . \\
7\end{array}$ & 973.4 & 8.2 & 96.9 \\
\hline & $5-1$ & 0.1629 & $\begin{array}{l}0.002 \\
0\end{array}$ & 1.636 & $\begin{array}{l}0.02 \\
2\end{array}$ & 1009.7 & $\begin{array}{l}23.4 \\
6\end{array}$ & 972.8 & $\begin{array}{l}10 . \\
9\end{array}$ & 984.2 & 8.3 & $\begin{array}{c}97.5 \\
\end{array}$ \\
\hline & $5-2$ & 0.1628 & $\begin{array}{l}0.002 \\
0\end{array}$ & 1.631 & $\begin{array}{l}0.02 \\
2\end{array}$ & 1005.0 & $\begin{array}{l}23.5 \\
0\end{array}$ & 972.3 & $\begin{array}{l}10 . \\
9\end{array}$ & 982.4 & 8.3 & 97.8 \\
\hline & $5-4$ & 0.1613 & $\begin{array}{l}0.001 \\
9\end{array}$ & 1.622 & $\begin{array}{l}0.02 \\
2\end{array}$ & 1012.2 & $\begin{array}{l}23.6 \\
9\end{array}$ & 964.0 & $\begin{array}{l}10 . \\
8\end{array}$ & 978.8 & 8.3 & 96.7 \\
\hline & 6-1 & 0.1680 & $\begin{array}{l}0.002 \\
1\end{array}$ & 1.681 & $\begin{array}{l}0.02 \\
5\end{array}$ & 1001.9 & $\begin{array}{l}27.4 \\
5\end{array}$ & 1001.0 & 11. & 1001.3 & 9.5 & 99.9 \\
\hline & $6-2$ & 0.1641 & $\begin{array}{l}0.002 \\
0\end{array}$ & 1.650 & $\begin{array}{l}0.02 \\
3\end{array}$ & 1013.1 & $\begin{array}{l}24.5 \\
1\end{array}$ & 979.2 & $\begin{array}{l}11 . \\
0\end{array}$ & 989.7 & 8.6 & 97.7 \\
\hline & $6-3$ & 0.1688 & $\begin{array}{l}0.002 \\
0\end{array}$ & 1.684 & $\begin{array}{l}0.02 \\
3\end{array}$ & 996.8 & 24.4 & 1005.3 & $\begin{array}{l}11 . \\
2\end{array}$ & 1002.6 & 8.6 & 100.6 \\
\hline & $6-4$ & 0.1687 & $\begin{array}{l}0.002 \\
0\end{array}$ & 1.669 & $\begin{array}{l}0.02 \\
3\end{array}$ & 978.4 & $\begin{array}{l}25.5 \\
8\end{array}$ & 1005.2 & $\begin{array}{l}11 . \\
3\end{array}$ & 996.8 & 8.9 & 101.9 \\
\hline & $6-5$ & 0.1687 & $\begin{array}{l}0.002 \\
0\end{array}$ & 1.669 & $\begin{array}{l}0.02 \\
3\end{array}$ & 979.7 & $\begin{array}{l}25.2 \\
0\end{array}$ & 1004.9 & $\begin{array}{l}11 . \\
3\end{array}$ & 997.0 & 8.8 & 101.8 \\
\hline & $7-1$ & 0.1613 & $\begin{array}{l}0.002 \\
0\end{array}$ & 1.620 & $\begin{array}{l}0.02 \\
2\end{array}$ & 1009.7 & $\begin{array}{l}24.9 \\
2\end{array}$ & 964.1 & $\begin{array}{l}10 . \\
8\end{array}$ & 978.1 & 8.7 & 96.9 \\
\hline & $7-2$ & 0.1663 & $\begin{array}{l}0.002 \\
0\end{array}$ & 1.666 & $\begin{array}{l}0.02 \\
6\end{array}$ & 1004.2 & $\begin{array}{l}29.0 \\
3\end{array}$ & 991.7 & $\begin{array}{l}11 . \\
3\end{array}$ & 995.6 & 9.9 & 99.1 \\
\hline & $7-3$ & 0.1675 & $\begin{array}{l}0.002 \\
0\end{array}$ & 1.677 & $\begin{array}{l}0.02 \\
4\end{array}$ & 1004.3 & $\begin{array}{l}25.6 \\
6\end{array}$ & 998.1 & $\begin{array}{l}11 . \\
2\end{array}$ & 1000.0 & 9.0 & 99.6 \\
\hline $\begin{array}{l}\text { 13-TC- } \\
5008\end{array}$ & $1-1$ & 0.1700 & $\begin{array}{l}0.002 \\
1\end{array}$ & 1.678 & $\begin{array}{l}0.02 \\
3\end{array}$ & 974.6 & 24.7 & 1012.3 & $\begin{array}{l}11 . \\
6\end{array}$ & 1000.4 & 8.8 & 102.6 \\
\hline & $1-2$ & 0.1689 & $\begin{array}{l}0.002 \\
1\end{array}$ & 1.703 & $\begin{array}{l}0.02 \\
7\end{array}$ & 1018.8 & 29.2 & 1005.8 & $\begin{array}{l}11 . \\
7\end{array}$ & 1009.8 & $\begin{array}{l}10 . \\
1\end{array}$ & 99.1 \\
\hline 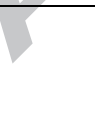 & $2-1$ & 0.1689 & $\begin{array}{l}0.002 \\
1\end{array}$ & 1.745 & $\begin{array}{l}0.02 \\
7\end{array}$ & 1067.5 & 28.3 & 1005.9 & $\begin{array}{l}11 . \\
7\end{array}$ & 1025.4 & $\begin{array}{l}10 . \\
0\end{array}$ & 96.1 \\
\hline & $2-2$ & 0.1692 & $\begin{array}{l}0.002 \\
1\end{array}$ & 1.692 & $\begin{array}{l}0.02 \\
7\end{array}$ & 1001.0 & 29.7 & 1007.6 & $\begin{array}{l}11 . \\
8\end{array}$ & 1005.5 & $\begin{array}{l}10 . \\
2\end{array}$ & 100.4 \\
\hline & 3-1 & 0.1689 & $\begin{array}{l}0.002 \\
2\end{array}$ & 1.724 & $\begin{array}{l}0.03 \\
2\end{array}$ & 1041.7 & 35.6 & 1006.1 & $\begin{array}{l}12 . \\
0\end{array}$ & 1017.3 & $\begin{array}{l}12 . \\
0\end{array}$ & 97.7 \\
\hline & 3-2 & 0.1692 & $\begin{array}{l}0.002 \\
1\end{array}$ & 1.700 & $\begin{array}{l}0.02 \\
4\end{array}$ & 1010.8 & 25.3 & 1007.7 & $\begin{array}{l}11 . \\
6\end{array}$ & 1008.6 & 9.0 & 99.8 \\
\hline
\end{tabular}


Turlin et al. - Unusual LREE-rich, post-tectonic, monazite- or allanite-bearing pegmatitic granites

in the central Grenville Province, Québec

\begin{tabular}{|c|c|c|c|c|c|c|c|c|c|c|c|}
\hline 4-2 & 0.1683 & $\begin{array}{l}0.002 \\
1\end{array}$ & 1.700 & $\begin{array}{l}0.02 \\
6\end{array}$ & 1020.8 & 27.9 & 1003.0 & $\begin{array}{l}11 . \\
6\end{array}$ & 1008.5 & 9.7 & 98.8 \\
\hline 5-1 & 0.1694 & $\begin{array}{l}0.002 \\
1\end{array}$ & 1.688 & $\begin{array}{l}0.02 \\
5\end{array}$ & 993.4 & 27.0 & 1008.8 & $\begin{array}{l}11 . \\
7\end{array}$ & 1003.9 & 9.4 & 101.1 \\
\hline $5-2$ & 0.1688 & $\begin{array}{l}0.002 \\
1\end{array}$ & 1.690 & $\begin{array}{l}0.02 \\
7\end{array}$ & 1003.3 & 29.2 & 1005.3 & $\begin{array}{l}11 . \\
7\end{array}$ & 1004.6 & 10. & 100.1 \\
\hline $5-3$ & 0.1686 & $\begin{array}{l}0.002 \\
1\end{array}$ & 1.659 & $\begin{array}{l}0.02 \\
7\end{array}$ & 967.2 & 31.2 & 1004.6 & $\begin{array}{l}11 . \\
8\end{array}$ & 992.8 & $\begin{array}{l}10 . \\
5\end{array}$ & 102.6 \\
\hline $5-4$ & 0.1686 & $\begin{array}{l}0.002 \\
1\end{array}$ & 1.699 & $\begin{array}{l}0.02 \\
5\end{array}$ & 1015.5 & 27.5 & 1004.6 & 11. & 1008.0 & 9.6 & 99.3 \\
\hline 6-1 & 0.1686 & $\begin{array}{l}0.002 \\
1\end{array}$ & 1.684 & $\begin{array}{l}0.02 \\
6\end{array}$ & 998.4 & 28.5 & 1004.4 & $\begin{array}{l}11 . \\
7\end{array}$ & 1002.4 & 9.8 & 100.4 \\
\hline $7-1$ & 0.1686 & $\begin{array}{l}0.002 \\
1\end{array}$ & 1.706 & $\begin{array}{l}0.02 \\
8\end{array}$ & 1024.6 & 30.8 & 1004.4 & $\begin{array}{l}11 . \\
8\end{array}$ & 1010.7 & $\begin{array}{l}10 . \\
6\end{array}$ & 98.6 \\
\hline $7-2$ & 0.1695 & $\begin{array}{l}0.002 \\
2\end{array}$ & 1.694 & $\begin{array}{l}0.02 \\
9\end{array}$ & 1000.0 & 32.2 & 1009.4 & $\begin{array}{l}11 . \\
9\end{array}$ & 1006.4 & $\begin{array}{l}10 . \\
9\end{array}$ & 100.6 \\
\hline 8-1 & 0.1684 & $\begin{array}{l}0.002 \\
1\end{array}$ & 1.630 & 0.02 & 933.9 & 31.8 & 1003.3 & $\begin{array}{l}11 . \\
8\end{array}$ & 981.7 & $\begin{array}{l}10 . \\
5\end{array}$ & 105.1 \\
\hline $8-2$ & 0.1688 & $\begin{array}{l}0.002 \\
2\end{array}$ & 1.669 & $\begin{array}{l}0.03 \\
0\end{array}$ & 978.2 & 34.7 & 1005.5 & $\begin{array}{l}12 . \\
0\end{array}$ & 996.9 & $\begin{array}{l}11 . \\
5\end{array}$ & 101.9 \\
\hline $8-3$ & 0.1696 & 0.002 & 1.691 & $\begin{array}{l}0.03 \\
0\end{array}$ & 994.7 & 33.5 & 1009.9 & $\begin{array}{l}12 . \\
0\end{array}$ & 1005.0 & $\begin{array}{l}11 . \\
3\end{array}$ & 101.0 \\
\hline $9-1$ & 0.1678 & $\begin{array}{l}0.002 \\
2\end{array}$ & 1.714 & $\begin{array}{l}0.03 \\
1\end{array}$ & 1043.3 & 34.0 & 1000.2 & $\begin{array}{l}11 . \\
9\end{array}$ & 1013.7 & $\begin{array}{l}11 . \\
5\end{array}$ & 97.2 \\
\hline $9-2$ & 0.1690 & $\begin{array}{l}0.002 \\
1\end{array}$ & 1.715 & $\begin{array}{l}0.02 \\
9\end{array}$ & 1031.4 & 31.1 & 1006.4 & $\begin{array}{l}11 . \\
8\end{array}$ & 1014.2 & $\begin{array}{l}10 . \\
7\end{array}$ & 98.3 \\
\hline $9-3$ & 0.1689 & $\begin{array}{l}0.002 \\
2\end{array}$ & 1.685 & $\begin{array}{l}0.02 \\
9\end{array}$ & 995.9 & 32.9 & 1006.1 & $\begin{array}{l}11 . \\
9\end{array}$ & 1002.8 & $\begin{array}{l}11 . \\
1\end{array}$ & 100.7 \\
\hline $9-4$ & 0.1698 & $\begin{array}{l}0.002 \\
3\end{array}$ & 1.694 & $\begin{array}{l}0.03 \\
6\end{array}$ & 996.9 & 41.4 & 1010.8 & $\begin{array}{l}12 . \\
4\end{array}$ & 1006.3 & $\begin{array}{l}13 . \\
6\end{array}$ & 100.9 \\
\hline $9-5$ & 0.1684 & $\begin{array}{l}0.002 \\
2\end{array}$ & 1.701 & $\begin{array}{l}0.03 \\
3\end{array}$ & 1021.3 & 37.0 & 1003.4 & $\begin{array}{l}12 . \\
1\end{array}$ & 1008.9 & $\begin{array}{l}12 . \\
4\end{array}$ & 98.8 \\
\hline
\end{tabular}


Turlin et al. - Unusual LREE-rich, post-tectonic, monazite- or allanite-bearing pegmatitic granites

in the central Grenville Province, Québec

576 Table 6: Summary of the main characteristics of the REE-rich pegmatitic granite dykes from

577 the Lac Okaopéo region, first ordered by type of occurrence then from north to south.

578 Abbreviations: Aln-bearing = allanite-bearing pegmatitic granite dyke; ASI = Aluminum

579 Saturation Index given by the expression $\mathrm{ASI}=\mathrm{Al} /(\mathrm{Ca}-1.67 \mathrm{x} \mathrm{P}+\mathrm{Na}+\mathrm{K})$ (Frost et al.,

580 2001; Shand, 1943); Mnz-bearing = monazite-bearing pegmatitic granite dyke.

\begin{tabular}{|c|c|c|c|c|c|c|c|c|c|}
\hline \multirow[t]{2}{*}{$\begin{array}{l}\text { Type of } \\
\text { REE } \\
\text { occurren } \\
\text { ce }\end{array}$} & $\begin{array}{l}\text { Outcro } \\
\text { p n }^{\circ}\end{array}$ & Field expression & Dip & Contact & $\begin{array}{l}\text { Texture } \\
\text { (from } \\
\text { contact } \\
\text { towards } \\
\text { core) }\end{array}$ & $\begin{array}{l}\text { Accesso } \\
\text { ry } \\
\text { mineral } \\
\mathbf{s}^{1}\end{array}$ & $\begin{array}{l}\text { Geochemic } \\
\text { al features }\end{array}$ & $\begin{array}{l}\text { Geochronolo } \\
\text { gy (U-Pb on } \\
\text { monazite) }\end{array}$ & \\
\hline & & & & & & Type & $\begin{array}{l}\text { REE- } \\
\text { bearing } \\
\text { phase } \\
\text { compositio } \\
\text { n }\end{array}$ & & \\
\hline \multirow[t]{4}{*}{$\begin{array}{l}\text { Mnz- } \\
\text { bearing }\end{array}$} & $\begin{array}{l}\text { 13- } \\
\text { AM-07 }\end{array}$ & Single dyke & $\begin{array}{l}\text { Steep- } \\
\text { dipping }\end{array}$ & $\begin{array}{l}\text { Slightly } \\
\text { diffuse - } \\
\text { Discorda } \\
\text { nt }\end{array}$ & $\begin{array}{l}\text { Stockschei } \\
\text { der contact } \\
-\quad \text { fine- } \\
\text { grained - } \\
\text { pegmatitic }\end{array}$ & $\begin{array}{l}\text { Zircon- } \\
\text { monazite }\end{array}$ & - & 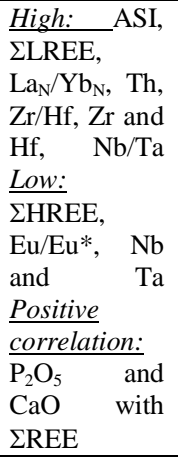 & - \\
\hline & $\begin{array}{l}\text { 13- } \\
\text { AM-10 }\end{array}$ & Single dyke & $\begin{array}{l}\text { Steep- } \\
\text { dipping }\end{array}$ & & $\begin{array}{l}\begin{array}{l}\text { Fine- } \\
\text { grained }\end{array} \\
\end{array}$ & $\begin{array}{l}\text { Zircon- } \\
\text { monazite }\end{array}$ & - & & - \\
\hline & $\begin{array}{l}\text { 13- } \\
\text { AM-13 }\end{array}$ & Single dyke & $\begin{array}{l}\text { Steep- } \\
\text { dipping }\end{array}$ & & $\begin{array}{l}\text { Patchy } \\
\text { zoning } \\
\text { (fined } \\
\text { grained to } \\
\text { pegmatitic) }\end{array}$ & $\begin{array}{l}\text { Zircon- } \\
\text { monazite } \\
-(\mathrm{Ce})(- \\
\text { minor } \\
\text { garnet } \\
\text { and Ti- } \\
\text { oxides) }\end{array}$ & $\begin{array}{l}\text { LREE-rich } \\
\text { cores/Th- } \\
\text { Si-rich } \\
\text { overgrowth } \\
\text { s }\end{array}$ & & $\begin{array}{l}996.7 \pm 5 \\
3 \mathrm{Ma}\end{array}$ \\
\hline & $\begin{array}{l}\text { 13-TC- } \\
5008\end{array}$ & Single dyke & $\begin{array}{l}\text { Steep- } \\
\text { dipping }\end{array}$ & $\begin{array}{l}\text { Locally } \\
\text { diffuse - } \\
\text { Discorda } \\
\text { nt }\end{array}$ & $\begin{array}{l}\text { Patchy } \\
\text { zoning } \\
\text { (coarse- } \\
\text { grained to } \\
\text { skeletal Bt- } \\
\text { rich) }\end{array}$ & $\begin{array}{l}\text { Zircon- } \\
\text { monazite } \\
-(\mathrm{Ce})(- \\
\text { minor } \\
\text { garnet })\end{array}$ & $\begin{array}{l}\text { Rather } \\
\text { homogeneo } \\
\text { us }\end{array}$ & & $\begin{array}{l}1005.4 \pm 4 \\
.4 \mathrm{Ma}\end{array}$ \\
\hline \multirow[t]{2}{*}{$\begin{array}{l}\text { Aln- } \\
\text { bearing }\end{array}$} & $\begin{array}{l}\text { 13-TC- } \\
5072\end{array}$ & Dyke swarm & $\begin{array}{l}\text { Steep- } \\
\text { dipping }\end{array}$ & $\begin{array}{l}\text { Slightly } \\
\text { diffuse - } \\
\text { Discorda } \\
\text { nt to sub- } \\
\text { concorda } \\
\text { nt }\end{array}$ & $\begin{array}{l}\text { Fine- } \\
\text { grained - } \\
\text { pegmatitic }\end{array}$ & $\begin{array}{l}\text { Zircon- } \\
\text { allanite- } \\
\text { (Ce) }\end{array}$ & $\begin{array}{l}\text { Homogeneo } \\
\text { us cores - } \\
\text { Fe-rich rims }\end{array}$ & 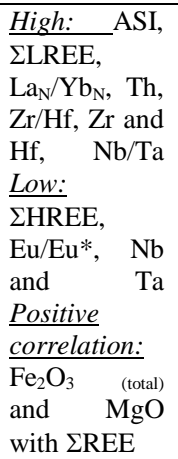 & - \\
\hline & $\begin{array}{l}\text { 13-FS- } \\
1202\end{array}$ & Dyke swarm & $\begin{array}{l}\text { Steep- } \\
\text { dipping }\end{array}$ & $\begin{array}{l}\text { Slightly } \\
\text { diffuse - } \\
\text { Discorda } \\
\text { nt }\end{array}$ & $\begin{array}{l}\text { Patchy to } \\
\text { layered } \\
\text { zoning } \\
\text { (fined } \\
\text { grained to }\end{array}$ & $\begin{array}{l}\text { Zircon- } \\
\text { allanite- } \\
\text { (Ce) }\end{array}$ & $\begin{array}{l}\text { LREE-rich } \\
-\quad \text { Fe-Ca- } \\
\text { LREE-rich } \\
\text { cores - Si- } \\
\text { rich/LREE- }\end{array}$ & & - \\
\hline
\end{tabular}


Turlin et al. - Unusual LREE-rich, post-tectonic, monazite- or allanite-bearing pegmatitic granites

in the central Grenville Province, Québec

${ }^{1}$ All samples are dominated by a quartz+K-feldspar+plagioclase \pm biotite assemblage.

$582{ }^{2}$ In comparison with the other dykes investigated in this study. 
Turlin et al. - Unusual LREE-rich, post-tectonic, monazite- or allanite-bearing pegmatitic granites

in the central Grenville Province, Québec

584 Appendix C: Planar fabrics measured on the pegmatitic granite dykes from the Lac Okaopéo

585 region, first ordered by type of occurrence then from north to south. Planar structures are

586 plotted in stereograms in Fig. 5 and are represented on detailed mapping of each outcrop from

587 Appendices A and B. 
Turlin et al. - Unusual LREE-rich, post-tectonic, monazite- or allanite-bearing pegmatitic granites

in the central Grenville Province, Québec

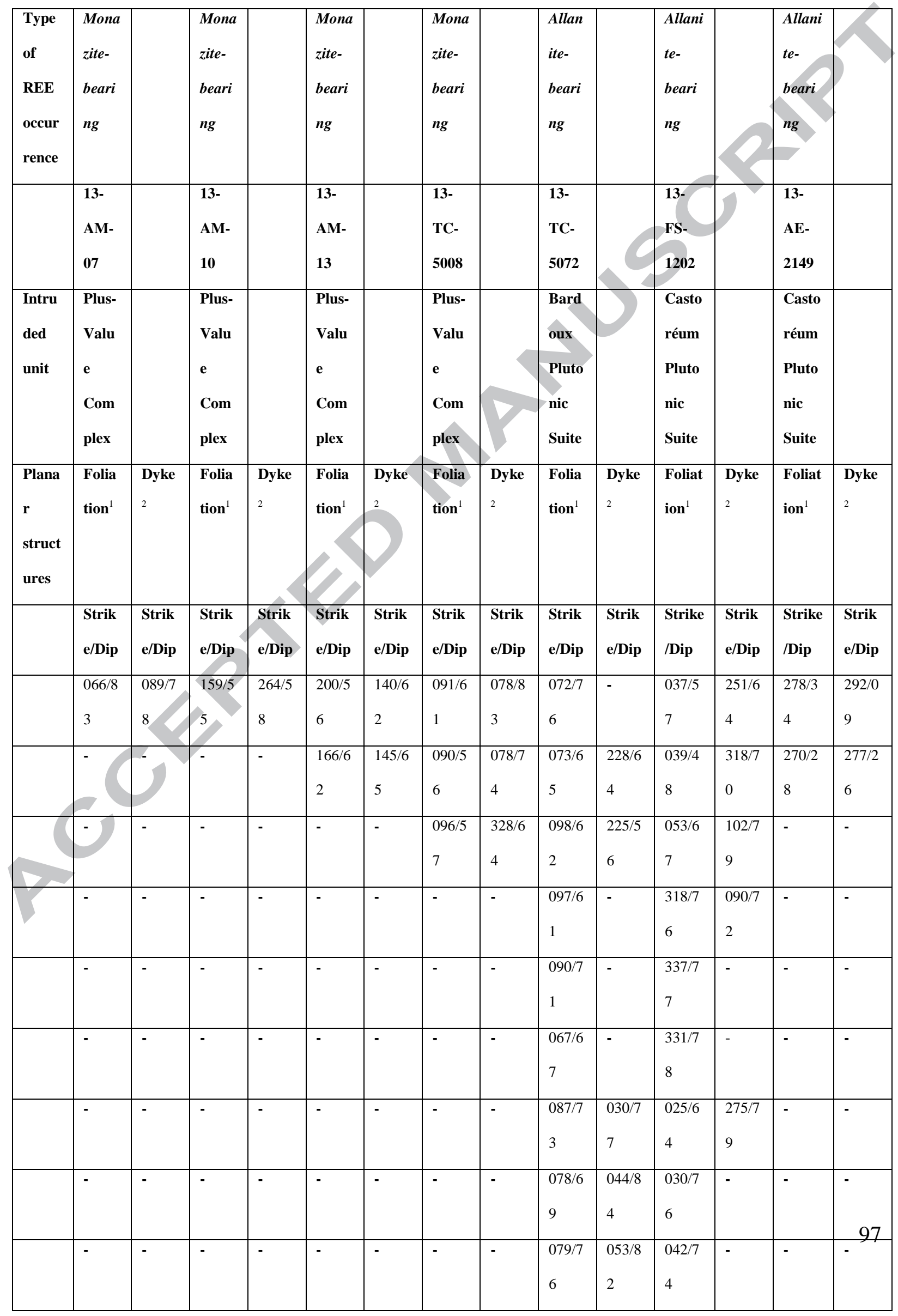


Turlin et al. - Unusual LREE-rich, post-tectonic, monazite- or allanite-bearing pegmatitic granites

in the central Grenville Province, Québec

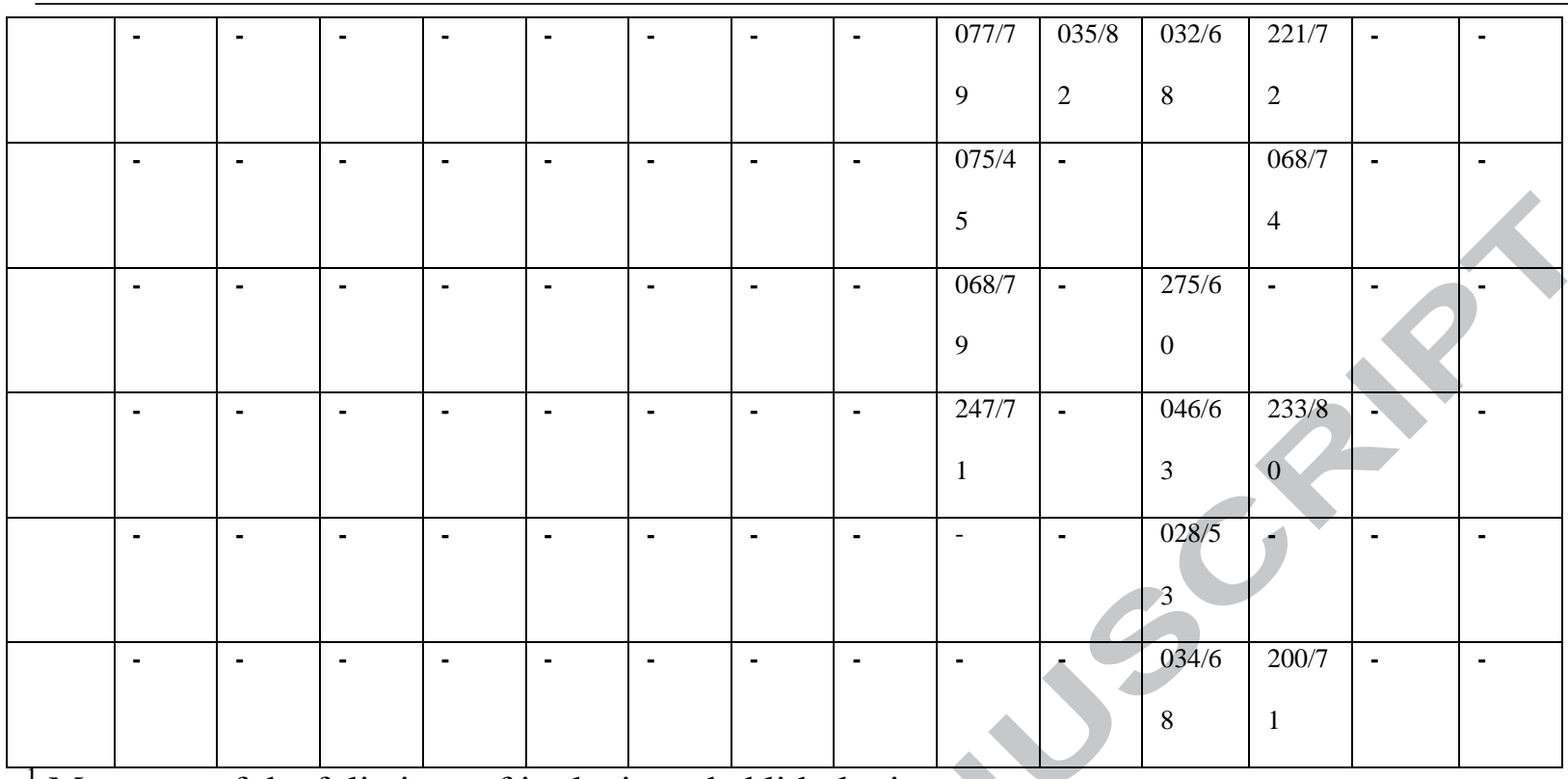

${ }^{2}$ Measures of the contacts between the REE-rich pegmatitic granite dykes and their host rocks 
Turlin et al. - Unusual LREE-rich, post-tectonic, monazite- or allanite-bearing pegmatitic granites

in the central Grenville Province, Québec

591 Appendix D: Operating conditions for the LA-ICP-MS equipment

\begin{tabular}{|c|c|}
\hline & U-Pb monazite analyses \\
\hline \multicolumn{2}{|l|}{$\begin{array}{l}\text { Laboratory \& Sample } \\
\text { Preparation }\end{array}$} \\
\hline Laboratory name & Géosciences Rennes, UMR CNRS 6118, Université Rennes 1, Rennes, France \\
\hline Sample type/mineral & Magmatic monazite \\
\hline Sample preparation & Thin-sections \\
\hline Imaging & $\begin{array}{l}\text { Hitachi S-4800 SEM, GeoRessources, UMR 7359, Université de Lorraine, Vandœuvre-lès- } \\
\text { Nancy, France }\end{array}$ \\
\hline \multicolumn{2}{|r|}{ 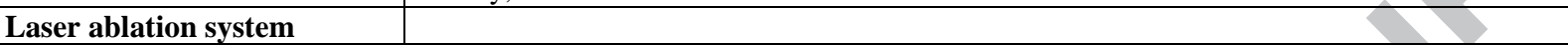 } \\
\hline Make, Model \& type & ESI NWR193UC, Excimer \\
\hline Ablation cell & ESI NWR TwoVol2 \\
\hline Laser wavelength & $193 \mathrm{~nm}$ \\
\hline Pulse width & $<5 \mathrm{~ns}$ \\
\hline Fluence & $6.5 \mathrm{~J} / \mathrm{cm}-2$ \\
\hline Repetition rate & $2 \mathrm{~Hz}$ \\
\hline Spot size & $10 \mu \mathrm{m}$ (round spot) \\
\hline Sampling mode / pattern & Single spot \\
\hline Carrier gas & $100 \% \mathrm{He}, \mathrm{Ar}$ make-up gas and $\mathrm{N}_{2}(3 \mathrm{ml} / \mathrm{mn})$ combined using in-house smoothing device \\
\hline Background collection & 20 seconds \\
\hline Ablation duration & 60 seconds \\
\hline Wash-out delay & 10 seconds \\
\hline Cell carrier gas flow $(\mathrm{He})$ & $0.75 \mathrm{l} / \mathrm{min}$ \\
\hline \multicolumn{2}{|l|}{ ICP-MS Instrument } \\
\hline Make, Model \& type & Agilent 7700x, Q-ICP-MS \\
\hline Sample introduction & Via conventional tubing \\
\hline RF power & $1350 \mathrm{~W}$ \\
\hline Sampler, skimmer cones & +2 \\
\hline Extraction lenses & X type \\
\hline Make-up gas flow (Ar) & $0.87 \mathrm{l} / \mathrm{min}$ \\
\hline Detection system & Single collector secondary electron multiplier \\
\hline Data acquisition protocol & Time-resolved analysis \\
\hline Scanning mode & Peak hopping, one point per peak \\
\hline Detector mode & $\begin{array}{l}\text { Pulse counting, dead time correction applied, and analog mode when signal intensity > } \\
10^{6} \mathrm{cps}\end{array}$ \\
\hline Masses measured & ${ }^{204}(\mathrm{Hg}+\mathrm{Pb}),{ }^{206} \mathrm{~Pb},{ }^{207} \mathrm{~Pb},{ }^{208} \mathrm{~Pb},{ }^{238} \mathrm{U}$ \\
\hline Sensitivity / Efficiency & $25000 \mathrm{cps} / \mathrm{ppm} \mathrm{Pb}(50 \mu \mathrm{m}, 10 \mathrm{~Hz})$ \\
\hline Dwell time per isotope & 10-30 ms depending on the masses \\
\hline \multicolumn{2}{|l|}{ Data Processing } \\
\hline Gas blank & 20 seconds on-peak \\
\hline Calibration strategy & $\begin{array}{l}\text { Moacir Monazite used as primary reference material, Manangoutry Monazite used as } \\
\text { secondary reference material (quality control) }\end{array}$ \\
\hline Reference Material info & Moacir (Gasquet et al., 2010) \\
\hline \multicolumn{2}{|l|}{$\begin{array}{l}\text { Manangoutry (Paquette and } \\
\text { Tiepolo, 2007) }\end{array}$} \\
\hline Data processing package & Glitter (Van Achterbergh et al., 2001) \\
\hline Quality control / Validation & Manangoutry: $554.8 \pm 4.2 \mathrm{Ma}(\mathrm{MSWD}=0.94 ; \mathrm{n}=8)$ (sample 13-AM-13) \\
\hline $\begin{array}{l}554.4 \pm 3.4 \mathrm{Ma} \\
(\mathrm{MSWD}=0.94 ; \mathrm{n}=8) \text { (sample } \\
13-\mathrm{TC}-5008)\end{array}$ & \\
\hline
\end{tabular}


Figure 1 (black and white; 2 columns fitting)

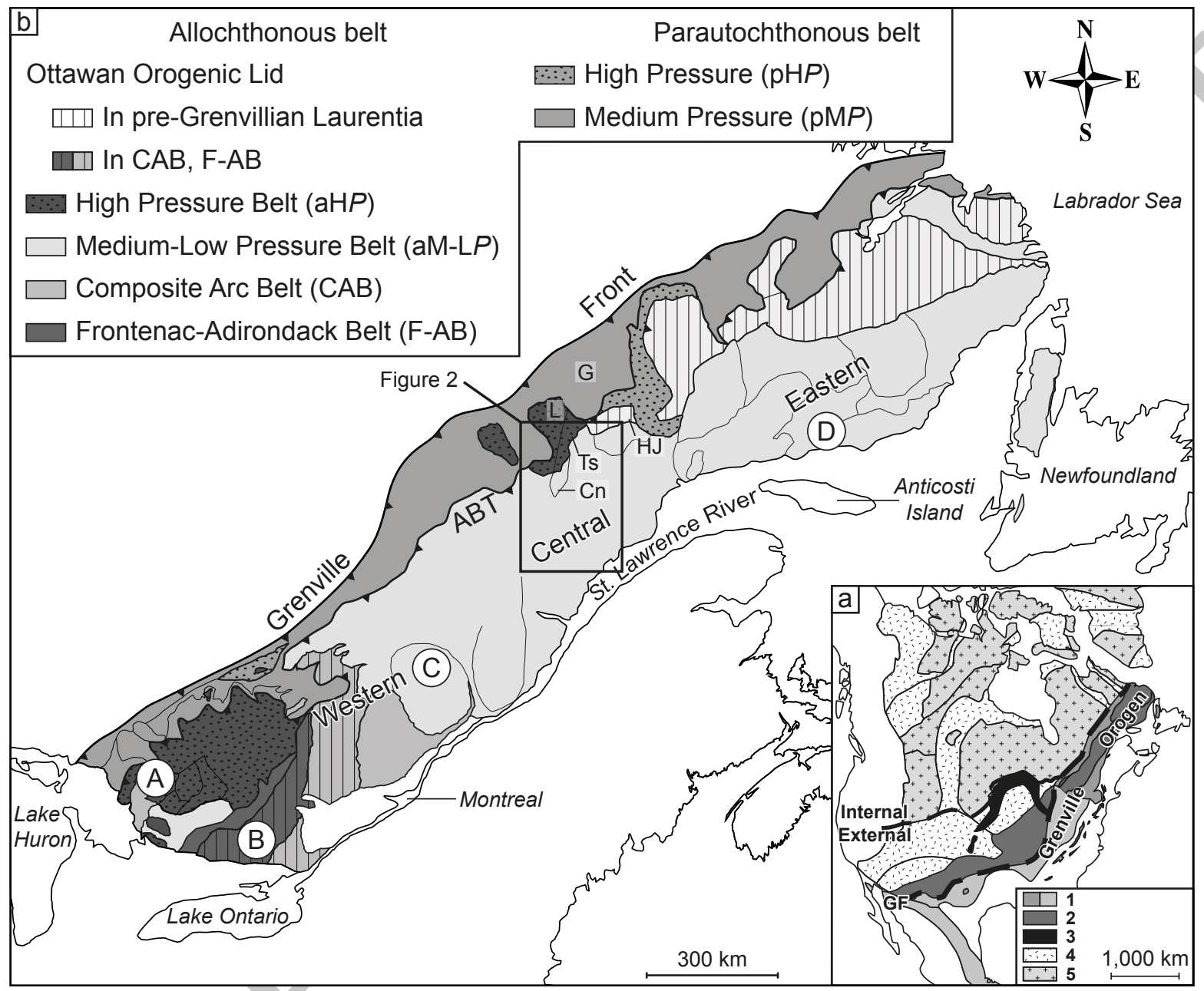


Figure 2 (color; 2 columns fitting)

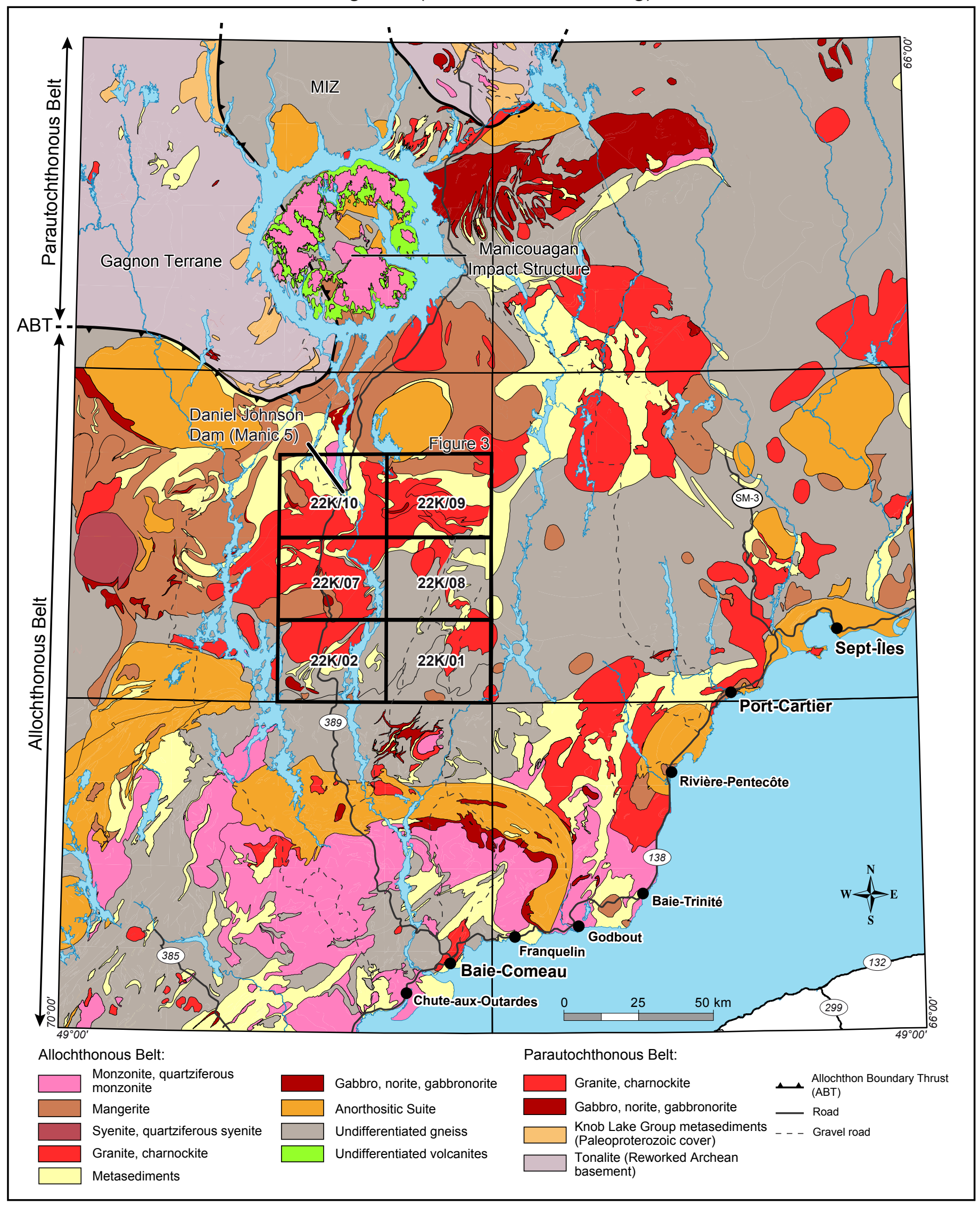




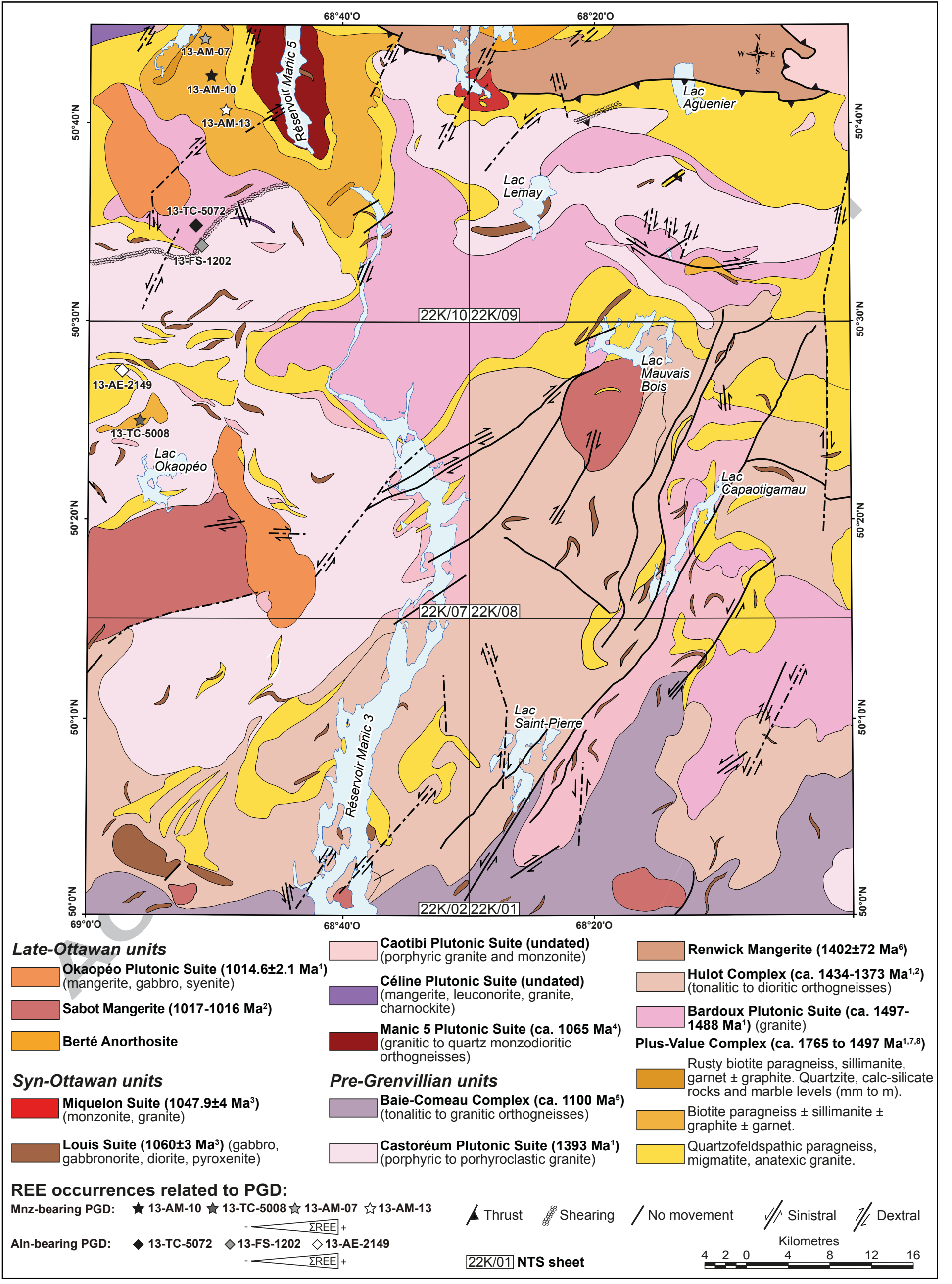




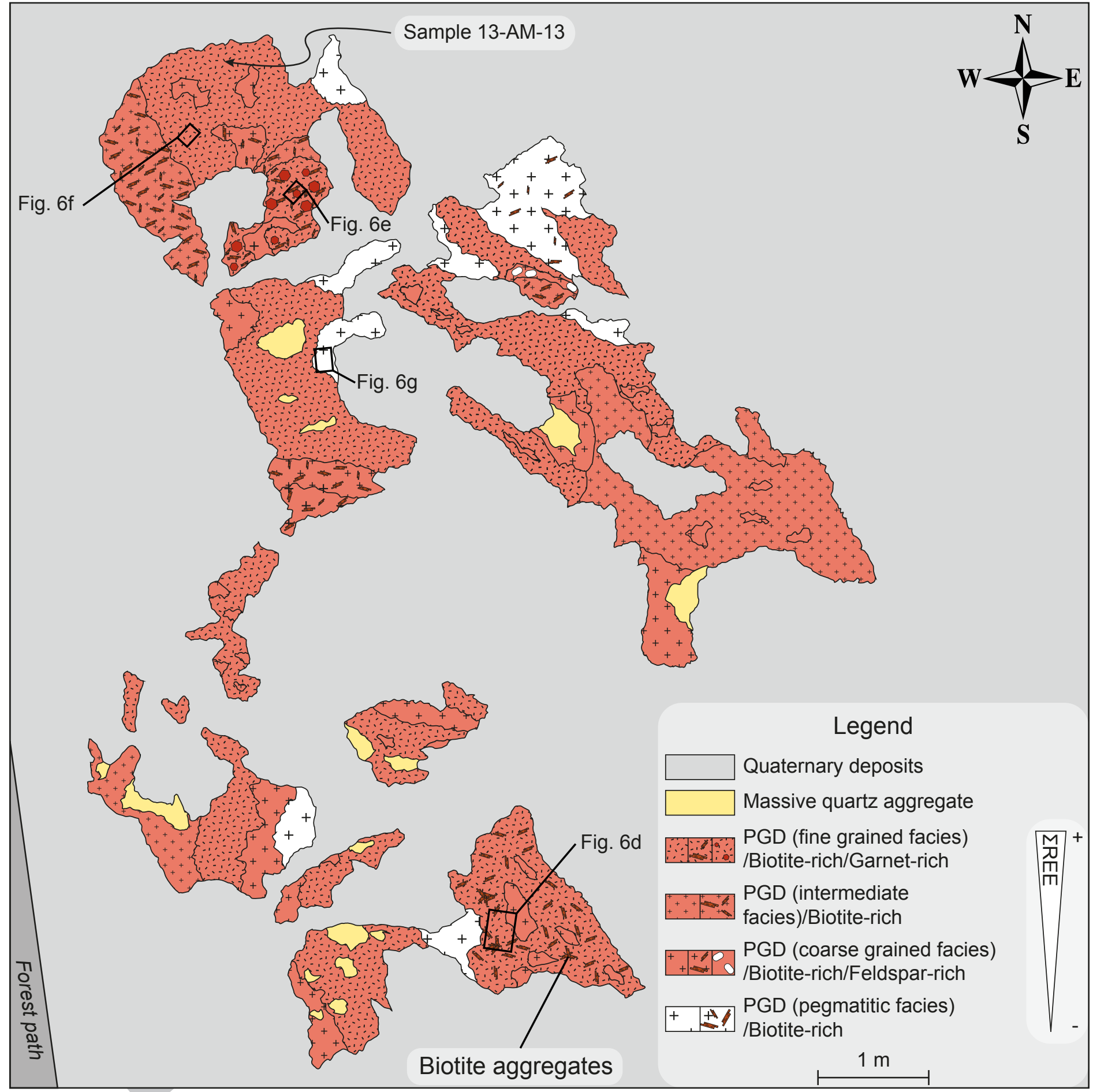


Figure 5 (black and white; 2 columns fitting)

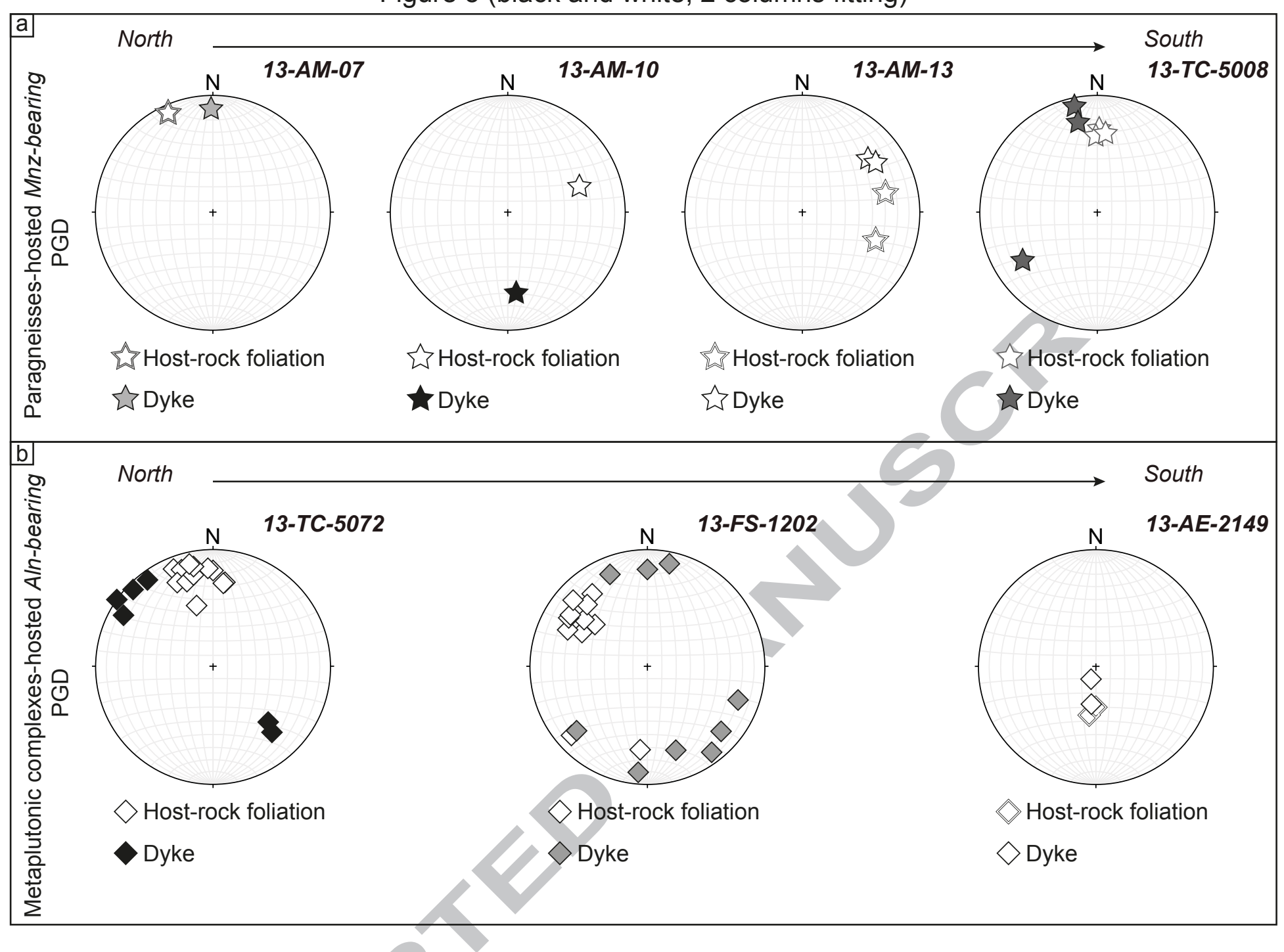



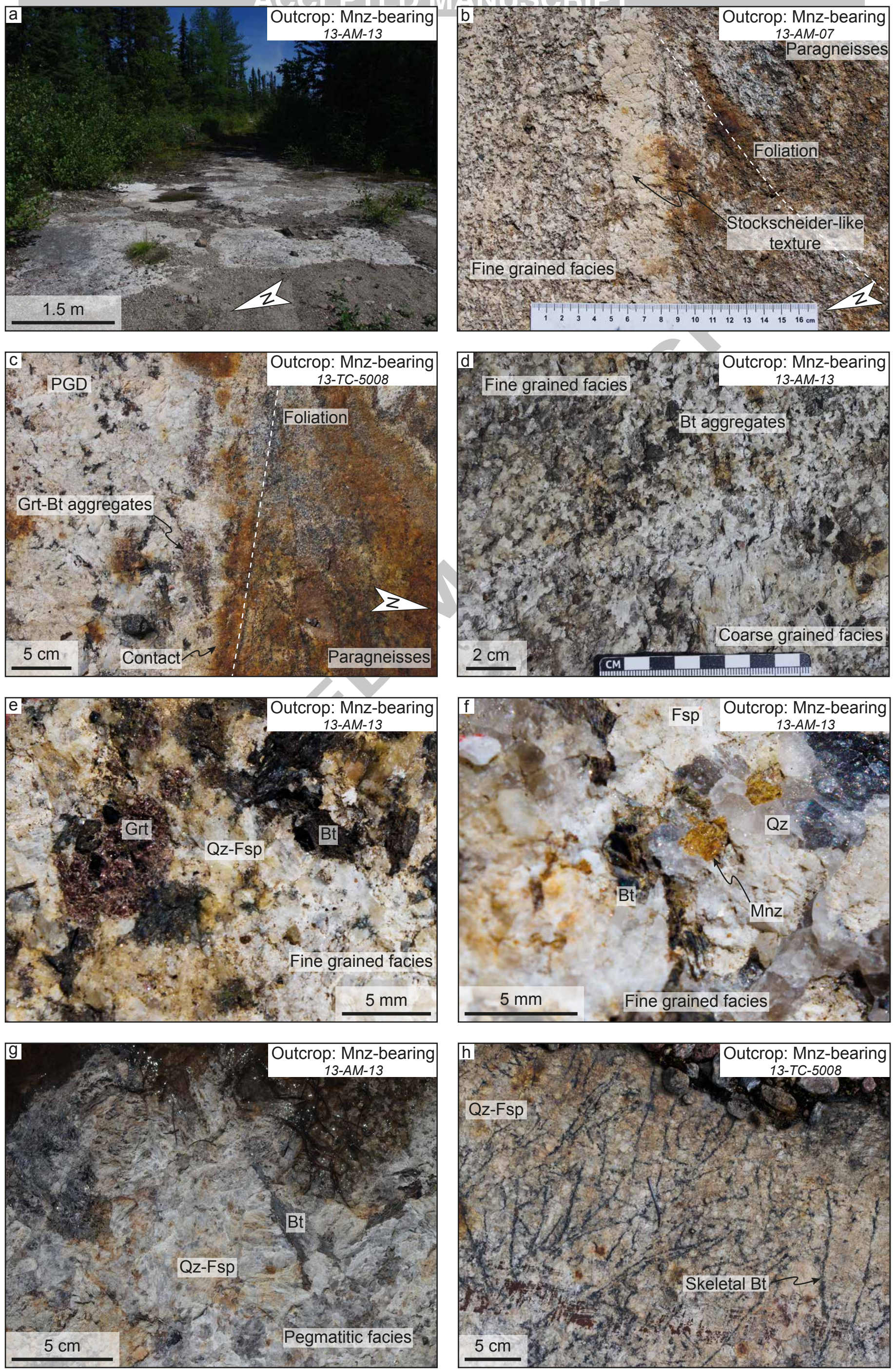
Figure 7 (color; 2 columns fitting)
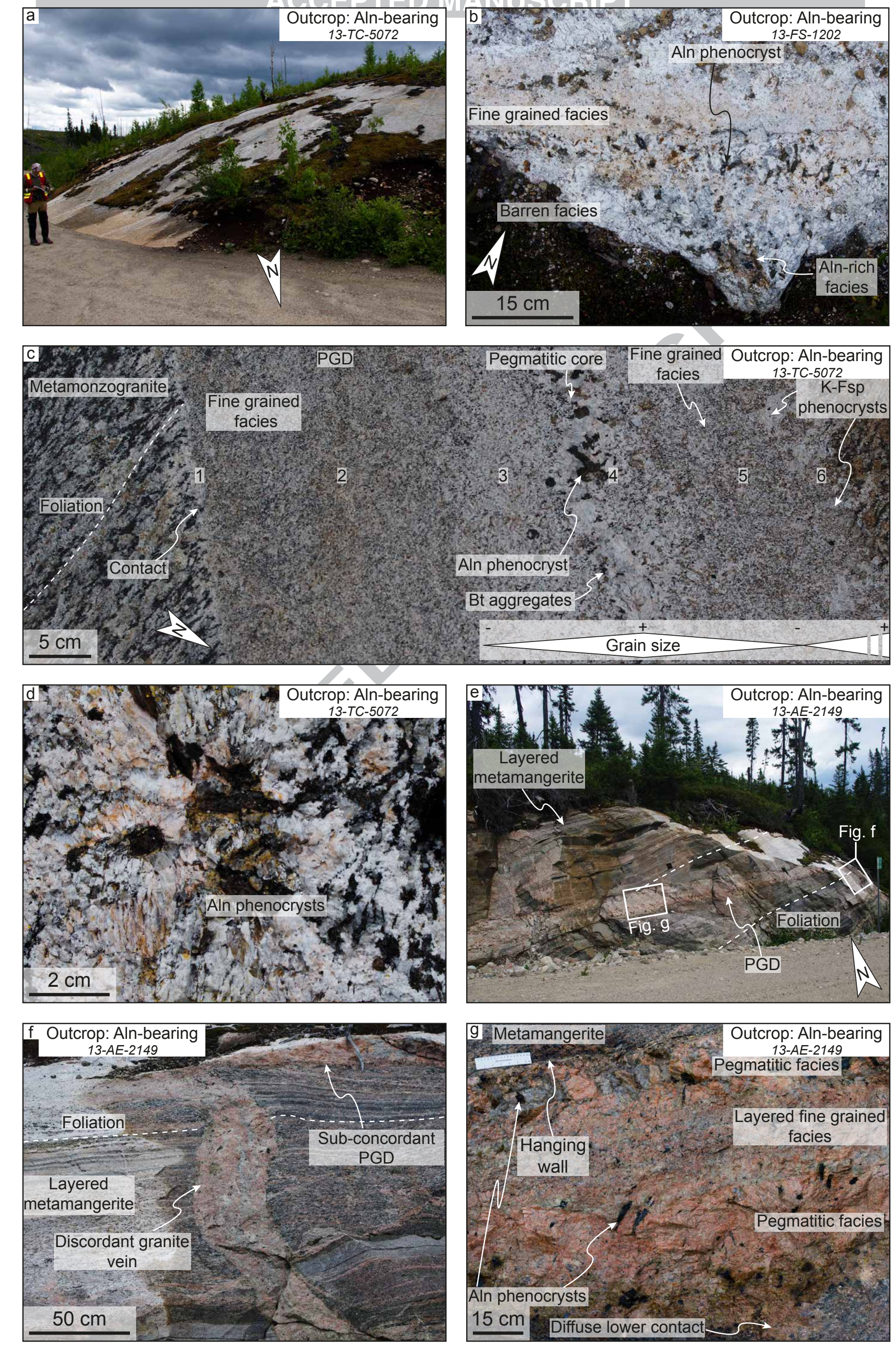
Figure 8 (color; 2 columns fitting)
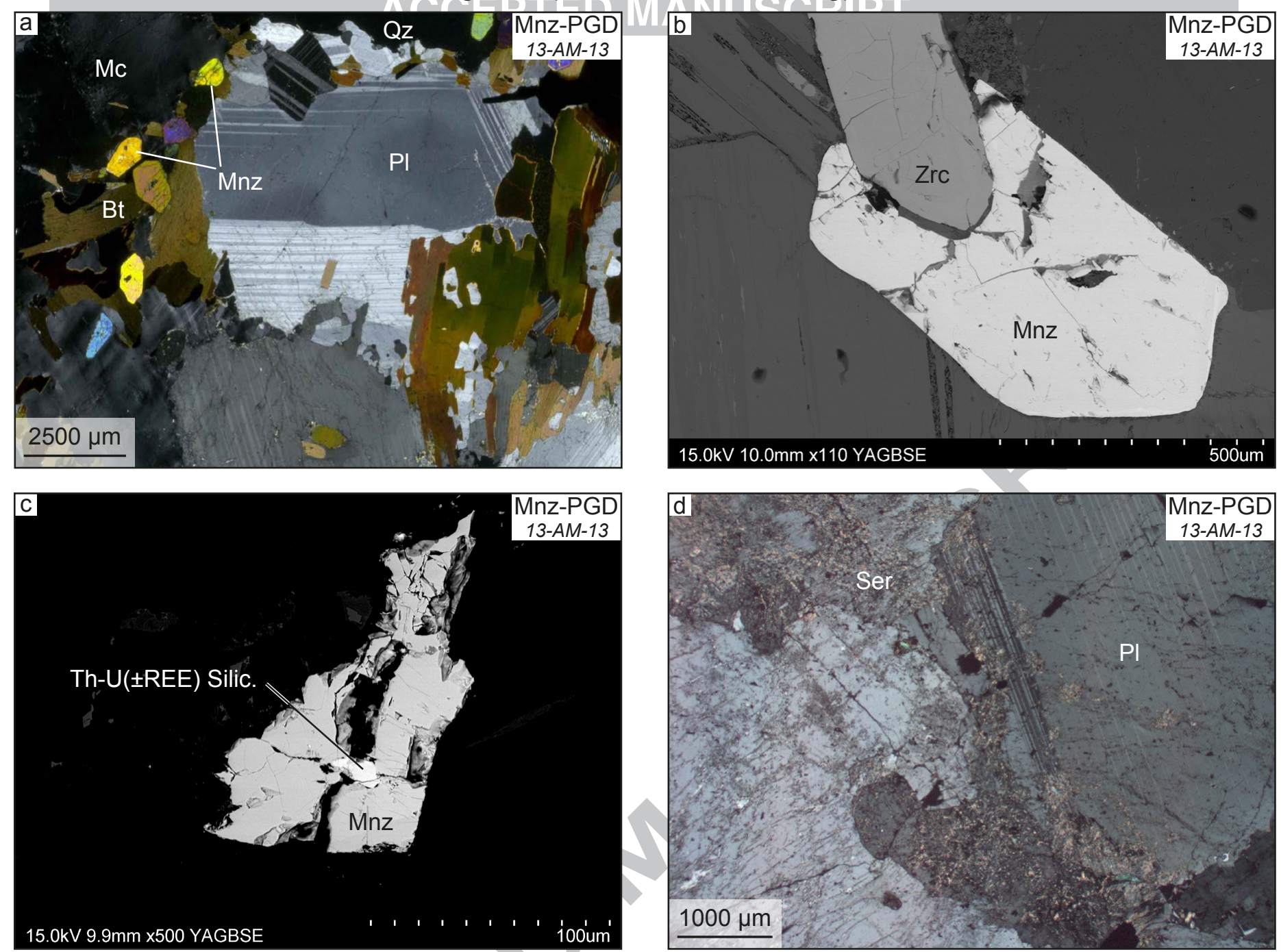


\section{ACCEPTED MANUSCRIPT}

Figure 9 (color; 2 columns fitting)
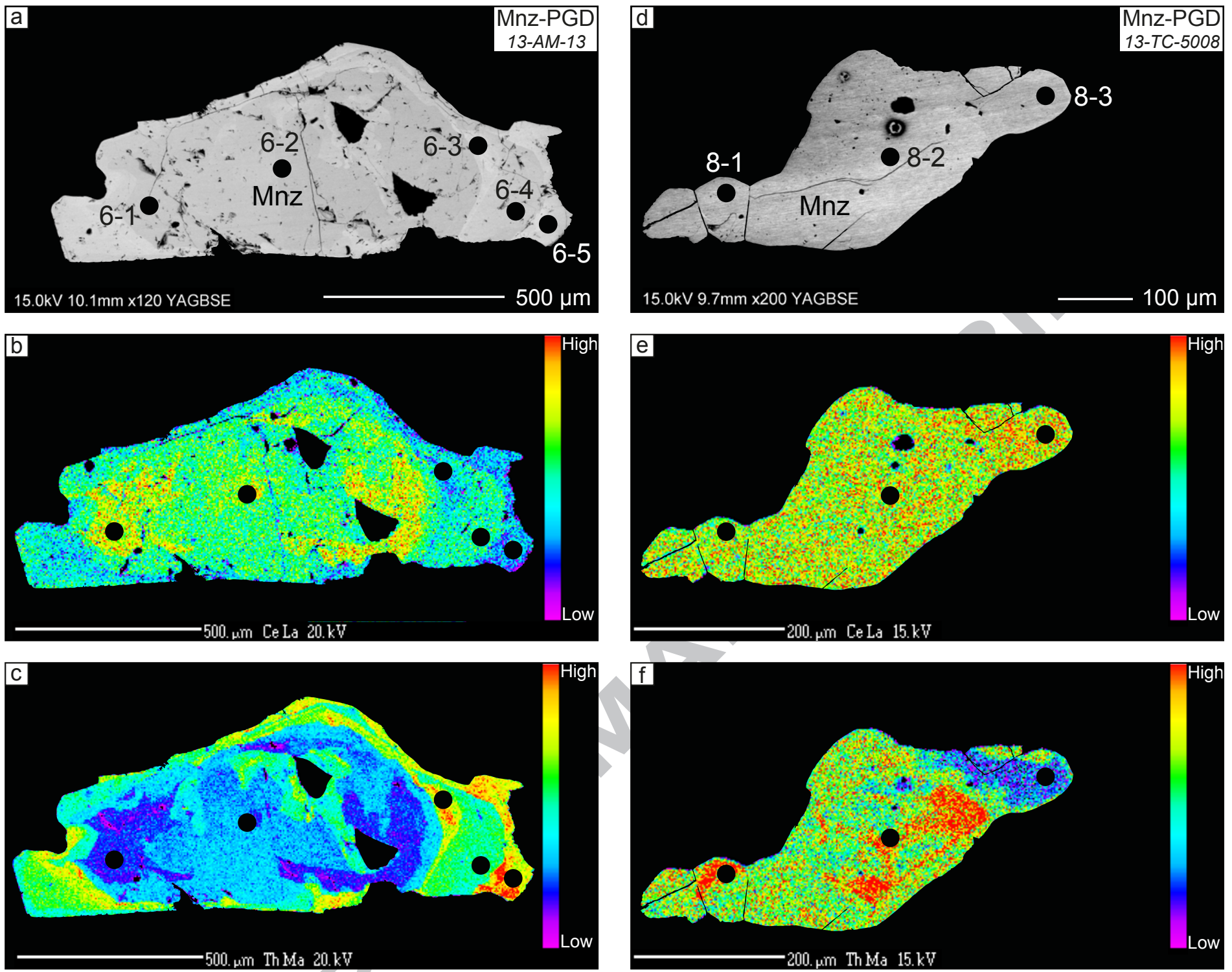

500. $\mathrm{mm}$ ThMa $20 . \mathrm{kV}$ 
a

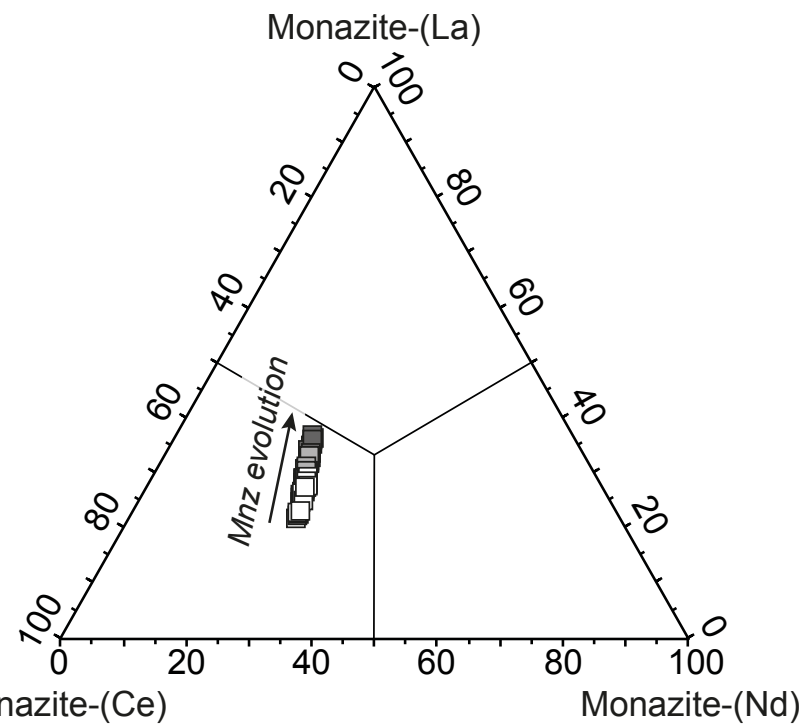

Monazte-( $\mathrm{Nd})$
C

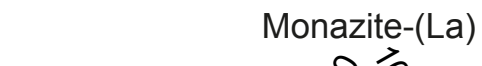

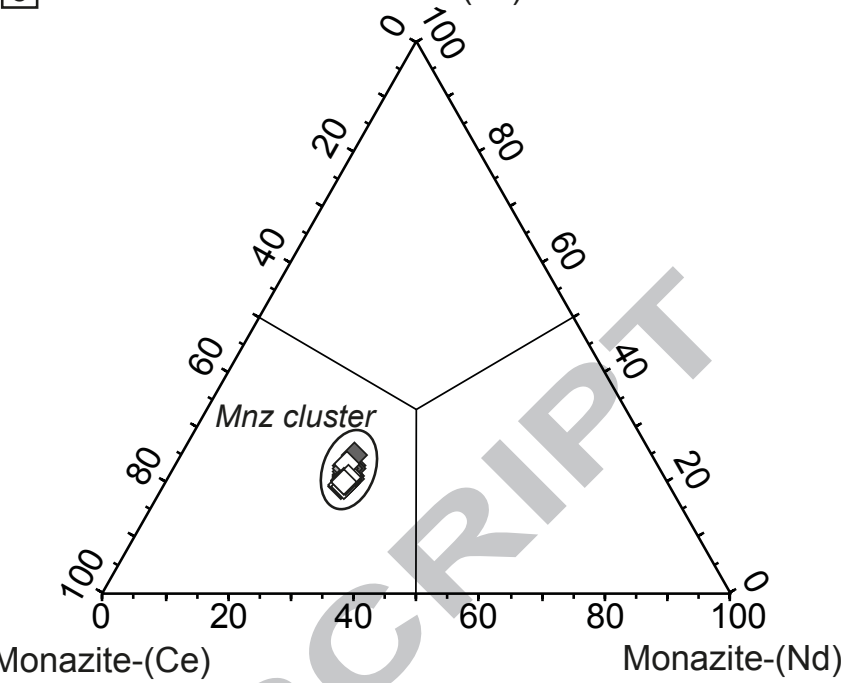
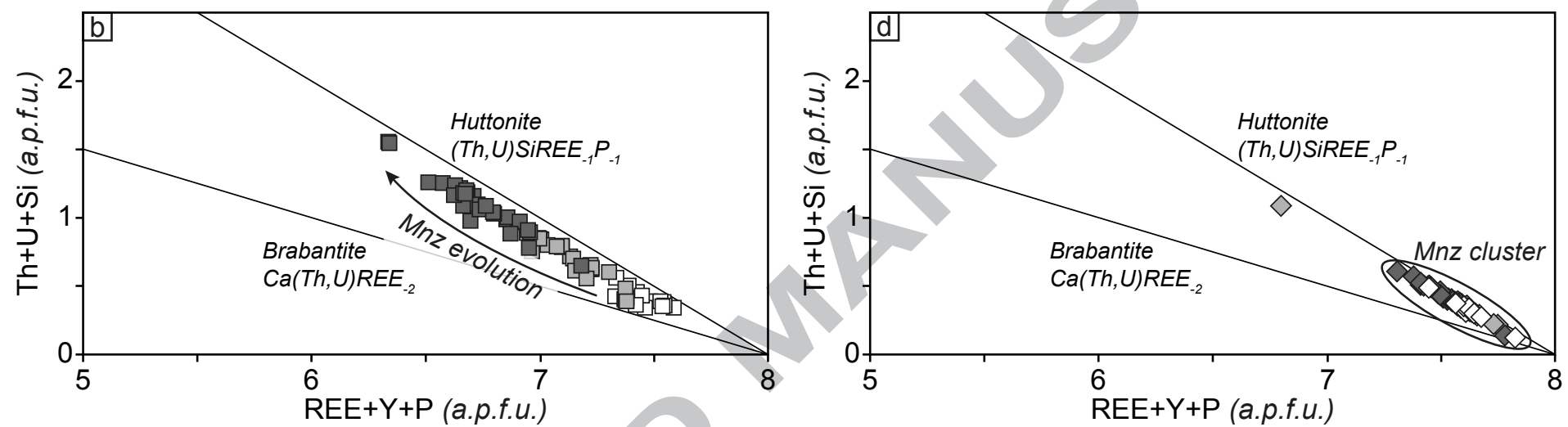

Monazite from PGD:

$\square$ 13-AM-13 (LREE(Ce)-rich zone, $n=20$ )

$\diamond 13-T C-5008$ (LREE(Ce)-rich zone, $n=17$ )

$\square$ 13-AM-13 (Intermediate zone, $n=23$ )

$\diamond 13-T C-5008$ (Intermediate zone, $n=27$ )

$\square$ 13-AM-13 (Th-Si-rich zone, $n=29$ )

13-TC-5008 (Th-Si-rich zone, $n=22$ ) 
Figure 11 (color; 2 columns fitting)
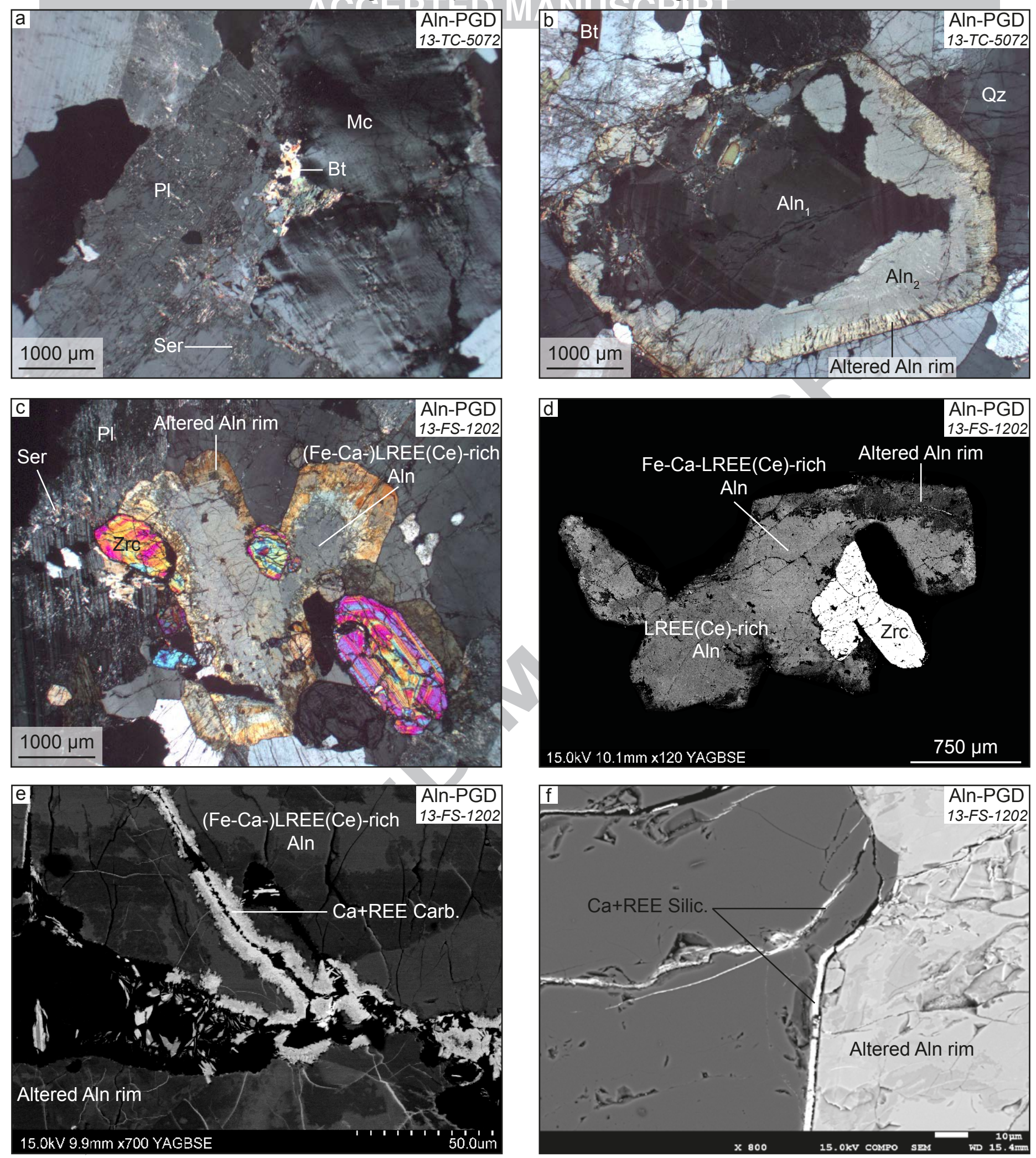
Figure 12 (black and white; 2 columns fitting)

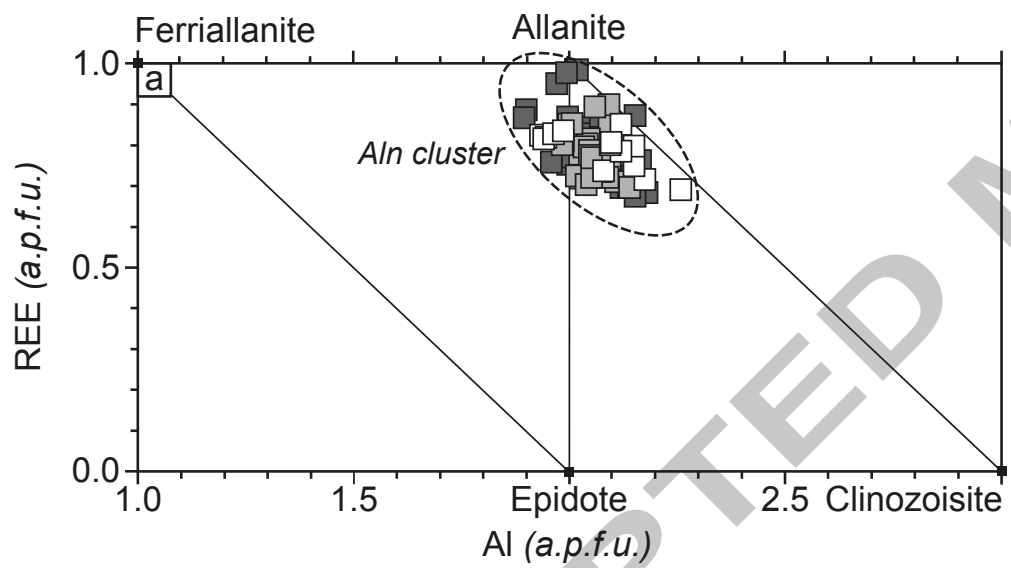

Allanite from PGD:

$\square$ 13-TC-5072 (Aln, zone, $n=14$ )

$\square$ 13-TC-5072 (Aln zone, $n=26$ )

$\square$ 13-TC-5072 (Alteration rim, $n=47$ )

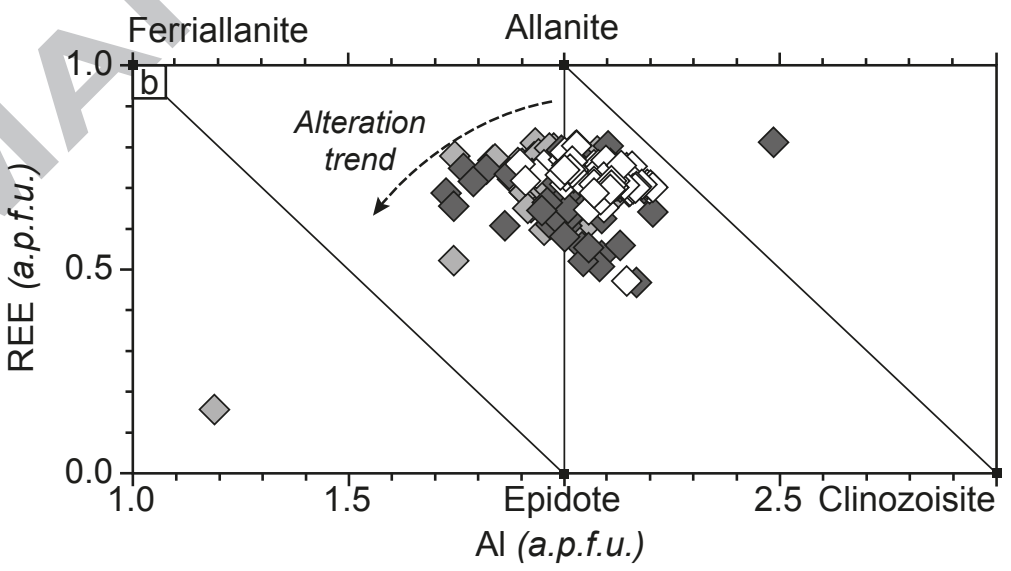

$\diamond 13-\mathrm{FS}-1202$ (LREE(Ce)-rich zone, $n=91$ )

$\checkmark 13-F S-1202$ (Fe-Ca-LREE(Ce)-rich zone, $n=122$ )

$\checkmark 13-\mathrm{FS}-1202$ (Alteration rim, $n=52$ ) 
Figure 13 (black and white; 2 columns fitting)
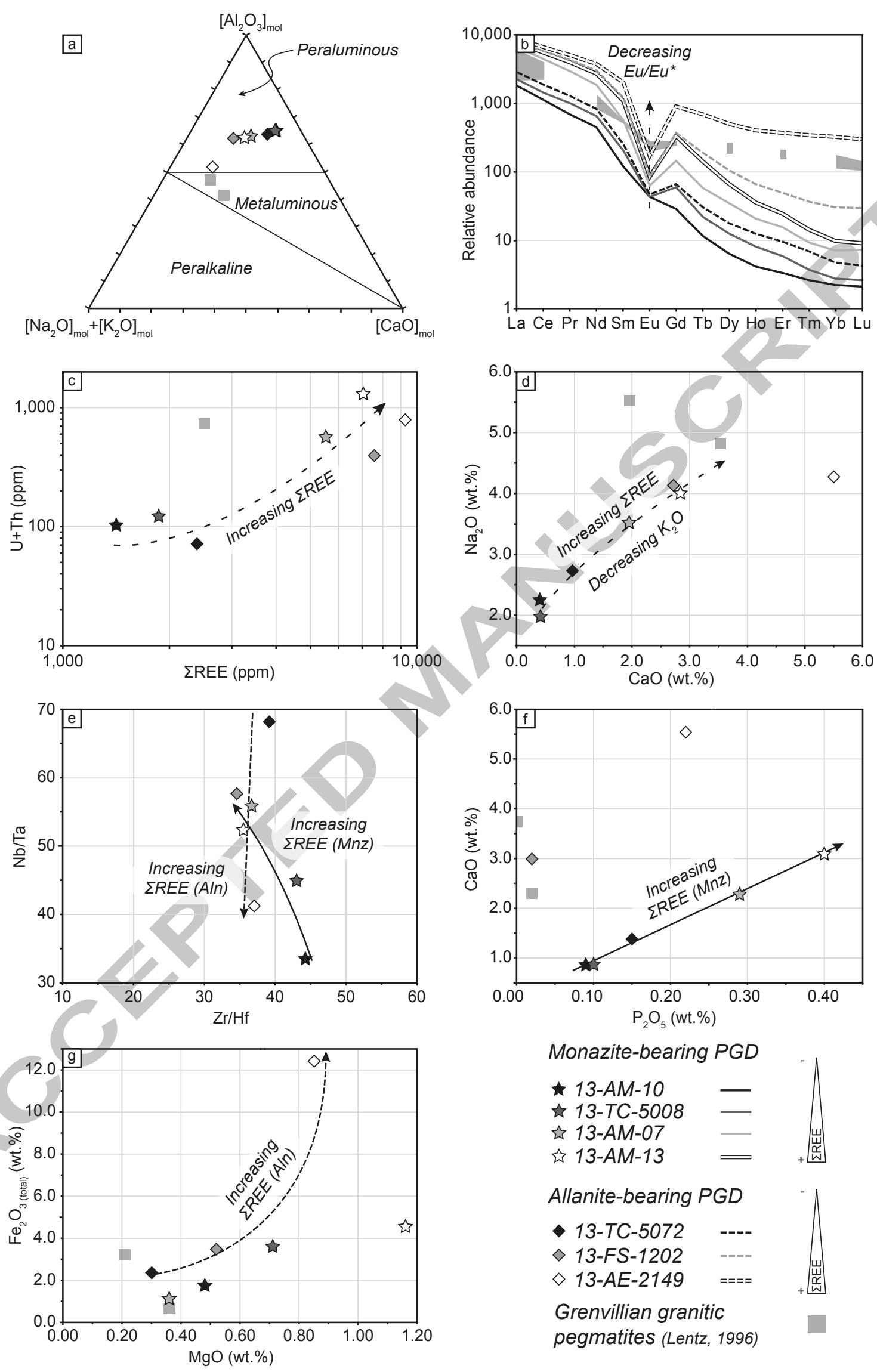

Monazite-bearing PGD

$\star 13-A M-10$

13-TC-5008

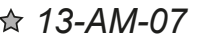

约 13-AM-13

Allanite-bearing $P G D$

-13-TC-5072 ----

$\diamond 13-F S-1202$

$\diamond 13-A E-2149 \quad====$

Grenvillian granitic

pegmatites (Lentz, 1996)

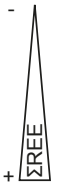


Figure 14 (black and white; 1 column fitting) data-point error ellipses are $2 \sigma$
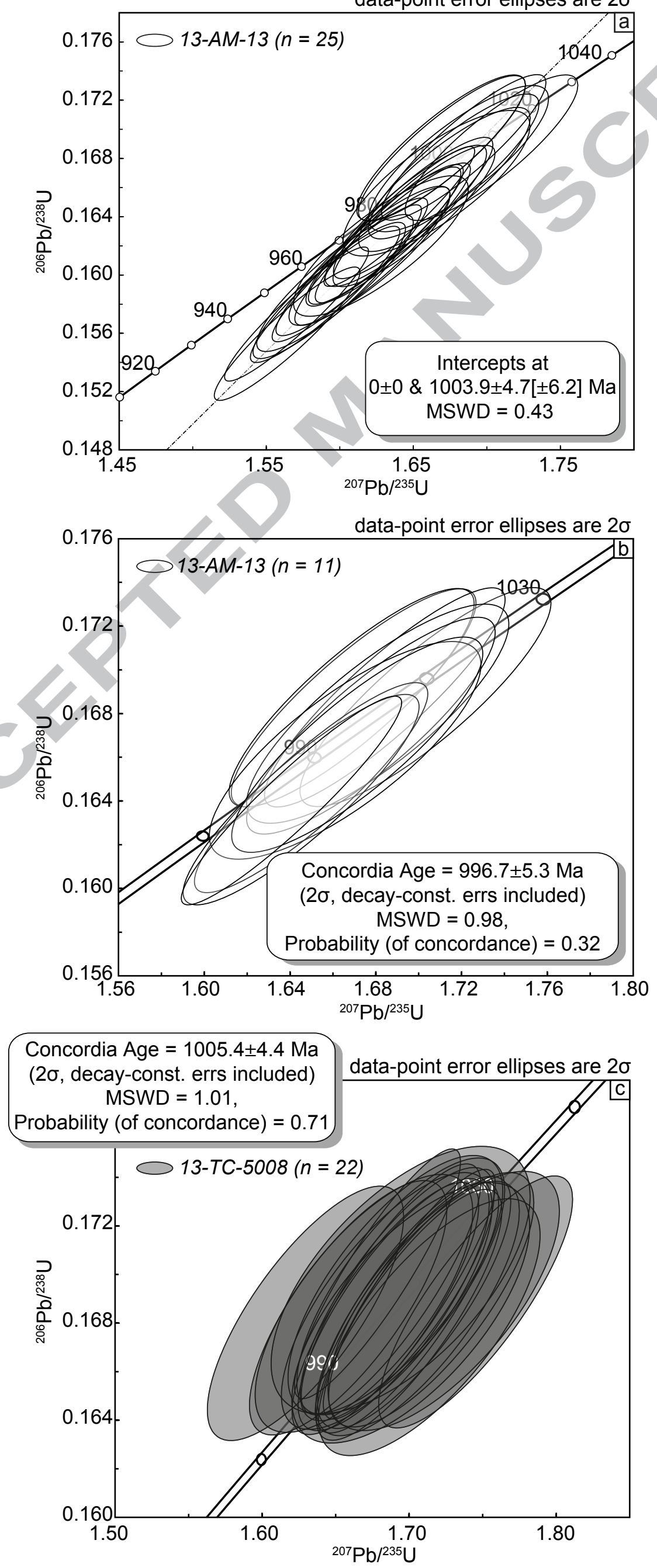
Two types of LREE-rich pegmatitic granite dykes (PGD): Monazite(Mnz)-bearing and Allanite(Aln)-bearing
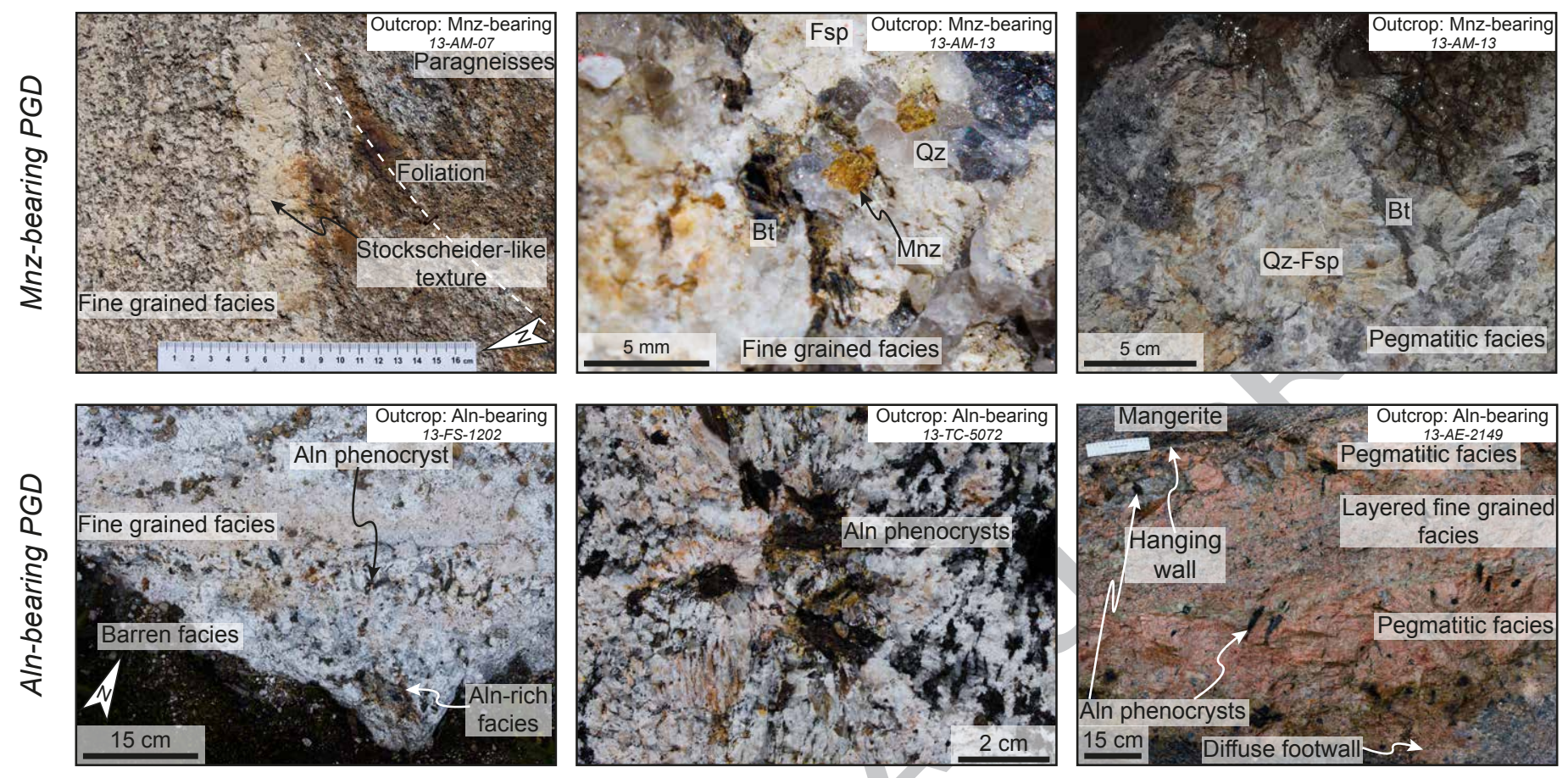

Whole-rock geochemistry of the Mnz- and Aln-bearing PGD
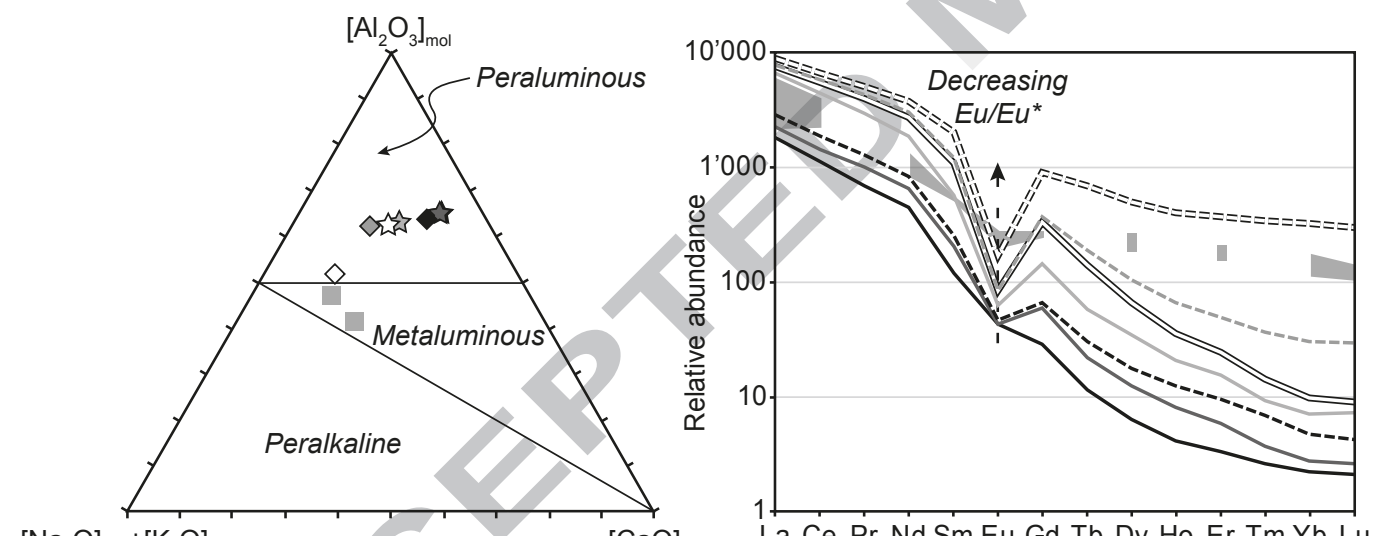

Monazite-bearing PGD

$\star 13-A M-10$

$13-T C-5008$

13-AM-07

13-AM-13

Allanite-bearing PGD

- 13-TC-5072 --.-

$\diamond 13-F S-1202$

$\diamond 13-A E-2149====$

Grenvillian granitic

$\left[\mathrm{Na}_{2} \mathrm{O}\right]_{\text {mol }}+\left[\mathrm{K}_{2} \mathrm{O}\right]_{\text {mol }}$

$[\mathrm{CaO}]_{\mathrm{mol}}$

La Ce Pr Nd Sm Eu Gd Tb Dy Ho Er Tm Yb Lu pegmatites (Lentz, 1996)

$\mathrm{U}-\mathrm{Pb}$ dating of magmatic monazite (LA-ICP-MS)
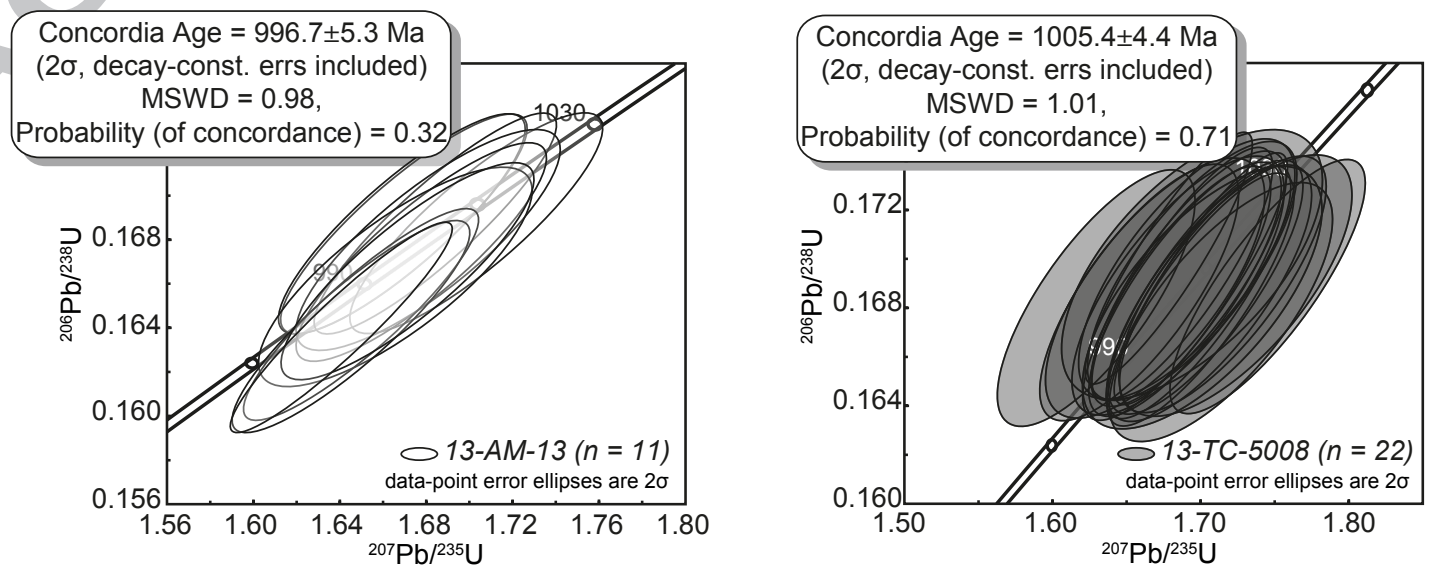
Turlin et al. - Unusual LREE-rich, post-tectonic, monazite- or allanite-bearing pegmatitic granites

in the central Grenville Province, Québec

\section{Research highlights:}

$\checkmark$ New LREE occurrences associated with peraluminous pegmatitic granite dykes in the central Grenville

$\checkmark$ Unusual LREE mineralization hosted either in monazite (paragneiss-hosted pegmatitic granite) or allanite (meta-igneous complexes-hosted pegmatitic granite)

$\checkmark$ A peraluminous character associated with a peralkaline behavior of trace elements and in contrast with the formation of allanite

$\checkmark$ First evidence of monazite-only LREE mineralization in a pegmatitic granite in the Grenville Province

$\checkmark$ A post-tectonic emplacement in the Allochthonous Belt associated with the initiation of the crustal thickening of the underlying Parautochthonous Belt 